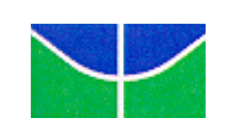

UNIVERSIDADE DE BRASÍIA

Faculdade de Economia, Administração e Contabilidade Programa de Pós-Graduação em Administração

Mestrado Profissional em Administração Pública

\title{
ANÁLISE DE CLUSTER DA VARIABILIDADE ORÇAMENTÁRIA NA ADMINISTRAÇÃO PÚBLICA FEDERAL
}

ALEX GONÇALVES BARBOSA

BRASÍLIA

2014 
ALEX GONÇALVES BARBOSA

\section{ANÁLISE DE CLUSTER DA VARIABILIDADE ORÇAMENTÁRIA NA ADMINISTRAÇÃO PÚBLICA FEDERAL}

Dissertação apresentada ao Programa de Pósgraduação em Administração - PPGA, da Faculdade de Economia, Administração e Contabilidade (FACE) da Universidade de Brasília (UnB) como requisito parcial à obtenção do título de Mestre Profissional em Administração.

Orientador: Prof. Dr. João Henrique Pederiva

\section{BRASÍLIA-DF}

2014 
Barbosa, A. G.

Análise de Cluster da Variabilidade Orçamentária na Administração Pública Federal.

Dissertação (mestrado)-Universidade de Brasília.

Faculdade de Economia, Administração e Contabilidade.

Programa de Pós-Graduação em Administração.

Brasília: UnB, 2014.

Área de Concentração: Administração Pública

Orientador: Prof. Dr. João Henrique Pederiva

1. Variabilidade Orçamentária; 2. Orçamento público; 3. Análise de clusters; 4. Padrões orçamentários. 


\title{
ANÁLISE DE CLUSTER DA VARIABILIDADE ORÇAMENTÁRIA NA ADMNISTRAÇÃO PÚBLICA
}

\section{FEDERAL}

\begin{abstract}
Dissertação apresentada ao Programa de Pósgraduação em Administração - PPGA, da Faculdade de Economia, Administração e Contabilidade (FACE) da Universidade de Brasília (UnB) como requisição parcial à obtenção do título de Mestre Profissional em Administração.
\end{abstract}

\section{BANCA EXAMINADORA:}

Prof. Dr. João Henrique Pederiva, Orientador - PPGA/UNB

Prof. Dr. Valmir Emil Hoffmann, Membro Interno - PPGA/UNB

Profa. Dra. Rita de Cássia Leal Fonseca dos Santos, Membro Externo SENADO FEDERAL 
Este trabalho é dedicado à

Ryan, Guilherme, Daniel, Ana Paula e Isabela, minha família

Meus pais, Jair e Aurora

Professor Pederiva, incentivador e companheiro nas novas descobertas 


\section{RESUMO}

O orçamento público é um instrumento que quantifica as decisões políticas, refletindo os acordos e interesses de diversos atores envolvidos. A legislação prevê que o orçamento é um instrumento de planejamento, e como tal implica a previsibilidade da execução dos acordos assinalados em sua aprovação. Para verificar se o orçamento público pode realmente ser considerado um instrumento de planejamento, foi realizada uma avaliação das variabilidades orçamentárias percentuais ao longo do processo orçamentário e a partir de diversas classificações dos gastos públicos. A metodologia utilizada foi a análise de clusters, considerando os tipos single, complete, average e Ward. O contexto dessa avaliação envolveu os modelos orçamentários, o planejamento e a teoria do Principal-Agente e a governança democrática, destacando o presidencialismo de coalizão e os ciclos eleitorais orçamentários ou Political Budget Cycle. Como resultados inesperados, as descrições das variabilidades orçamentárias demonstraram uma oscilação acentuada das agendas de gastos, no momento do pagamento dos restos a pagar autorizados em exercícios anteriores, em relação ao projeto de lei orçamentária, lei; autorizado, liquidado ou executado e pago com autorizações do exercício. Tampouco foi observada variação significativa entre os anos ao longo do período abordado (2002 a 2012). Conforme previsto, as emendas parlamentares individuais foram as que apresentaram maior variação percentual e as entidades da Administração indireta são mais suscetíveis às variações. Os resultados apontaram a existência de padrões de gastos hegemônicos no orçamento. A presença dos pressupostos do presidencialismo de coalizão podem ser inferidos, a partir das oscilações das emendas parlamentares individuais; a teoria do Principal-Agente é útil para o entendimento das variabilidades, percebendo-se uma dominância do Poder Executivo no processo; não foram encontradas evidências da existência do Political Budget Cycle no Brasil; e o modelo que melhor descreve o orçamento brasileiro é o incrementalismo, havendo espaço para explicações pontuais pelo julgamento serial e pelo equilíbrio pontuado. $\mathrm{O}$ achado mais destacado foi a instabilidade elevada das agendas, no pagamento dos restos a pagar, sugerindo que parte dos acordos firmados durante a apreciação legislativa sofrem alterações significativas no momento final de sua execução. Assim, é possível afirmar que a variabilidade dos restos a pagar compromete o orçamento como instrumento de planejamento no caso brasileiro.

Palavras-chave: 1. Variabilidade orçamentária; 2. Orçamento público; 3. Análise de Cluster; 4. Padrões orçamentários. 


\begin{abstract}
The public budget is a tool that quantifies the political decisions, reflecting the agreements and interests of various stakeholders. The law provides that the budget is a planning tool, and as such implies predictability of the implementation of the agreements indicated in its adoption. To verify the relevance of the public budget as a planning tool, the research examines the percentage of budgetary variability throughout the budgetary process and from various classifications of public spending. The methodology used was the cluster analysis, considering the types single, complete, average and Ward. The context of this evaluation included the budgetary models, the planning and the theory of Principal-Agent, democratic governance, highlighting the coalition presidentialism and budgetary election cycles or Political Budget Cycle. As an unexpected result, budgetary variability revealed a marked swing of the expenses agendas at the time of payment of the amounts paid with authorizations from others exercises ("restos a pagar") compared with the project of budgetary law, law, authorized, executed and paid with budgetary authorizations of the exercise. Besides that, there was no significant variation between years over the period covered (2002-2012). As expected, individual parliamentary amendments presented the largest variability and entities of indirect administration are more susceptible to variations. The results indicate the existence of hegemonic patterns in the budget. The presence of the assumptions of coalition presidentialism can be infered from the annual fluctuations in individual parliamentary amendments. The Principal-Agent theory is useful for understanding the variability, with a dominance of the executive branch in the budgetary process. There was no evidence of Political Budget Cycle in Brazil. The model that best describes the Brazilian budget is incrementalism, with space for specific explanations through the serial judgement and the punctuated equilibrium. The most amazing finding was the outstanding change of agenda in the payment of amounts to be paid ("restos a pagar"), suggesting that some of the agreements signed during legislative consideration may change in the final moment of his execution. Thus, it is possible to say that this variability of payments compromise the budget as an effective planning tool in the Brazilian federal budget.
\end{abstract}

Keywords: 1. Budgetary Variability. 2. Public budget. 3 Cluster Analysis. 4. Budgetary Standards. 


\section{LISTA DE FIGURAS}

Figura 1 - Processo orçamentário

Figura 2 - Processo de elaboração do PLOA

Figura 3 - Processo Orçamentário Legislativo.....

Figura 4 - Processo de execução discricionária da despesa pública . 55

Figura 5: distância entre clusters - singlelinkage..... 71

Figura 6: distância entre os clusters - Averagelinkage. 71

Figura 7: distância entre clusters - completelinkage. .72

Figura 8-Quantidade de unidades orçamentárias .76

Figura 9 - dendogramas por grupos para marcação das rodadas 80

Figura 10 - Observações x rodadas de clusters 82

Figura 11 - exclusões por tipo de despesa e por rodada 84

Figura 12 - Exclusões por ano e rodada. 86

Figura 13 - observações por tipo de uo e rodada 88

Figura 14 - observações por etapa e uo, sem e com stn2 .89

Figura 15 - observações por etapa e uo, após a $12^{\mathrm{a}}$ rodada, sem e com stn2. 90

Figura 16 - observações por etapa e tipo sem e com stn2. .91

Figura 17 - observações por etapa e ano sem e com stn2. .93

Figura 18 - exclusões por cluster e rodada. .96

Figura 19 - Padrão 3 por tipo e etapa .99

Figura 20; padrão 3 por tipo, poder e etapa. 101

Figura 21: padrão 3 por etapa e ano 102

Figura 22: padrão 1 por tipo e etapa 103

Figura 23: padrão 1 por etapa e tipos de uo e despesa 104

Figura 24: padrão 1 por etapa e ano 105

Figura 25:padrão 8 por tipo e etapa. 106

Figura 26: padrão 8 por etapa, tipo de uo e despesa... 107

Figura 27: padrão 8 por etapa e ano 107 


\section{LISTA DE TABELAS}

Tabela 1 - Descrição dos códigos das unidades orçamentárias ............................................62

Tabela 2 - Expectativa de variabilidade conforme tipos orçamentários ...................................66

Tabela 3- Prazos e atores principais das etapas orçamentárias ...............................................67

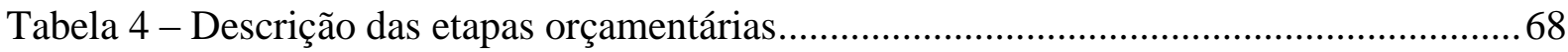

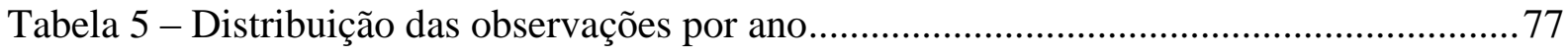

Tabela 6 - Distribuição das observações por espécie de unidade orçamentária ....................... 77

Tabela 7- Distribuição das unidades orçamentárias por Poder de Estado ................................ 78

Tabela 8 - Distribuição das observações por tipo …............................................................. 78

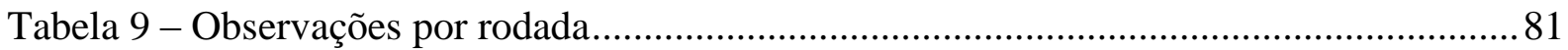

Tabela 10 - Exclusões por tipo de despesa e rodada (acumulativo) ….................................... 83

Tabela 11 - Exclusões por tipo e percentual até $12^{\mathrm{a}}$ rodada ................................................. 84

Tabela 12 - Observações e exclusões por ano e na $12^{\mathrm{a}}$ rodada.............................................. 85

Tabela 13 - Exclusões por tipo de unidade orçamentária e rodada ......................................... 87

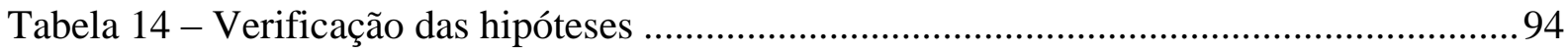

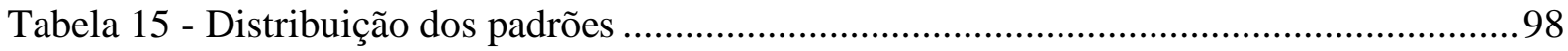

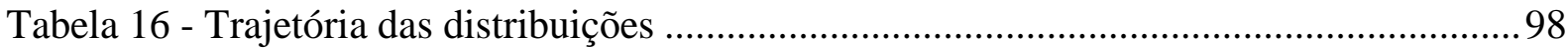




\section{LISTA DE SIGLAS}

CMO Comissão Mista de Orçamento

CON Congresso Nacional

CT Custos de Transação

CTE Custos de Transação Econômicos

CTP Custos de Transação Políticos

DNPM Departamento Nacional de Produção Mineral

EMBRAPA Empresa Brasileira de Pesquisa Agropecuária

FMI Fundo Monetário Internacional

FNS Fundo Nacional de Saúde

LDO Lei de Diretrizes Orçamentárias

LOA Lei Orçamentária Anual

LRF Lei de Responsabilidade Fiscal

MCTI Ministério da Ciência, Tecnologia e Inovação

MF Ministério da Fazenda

MJ Ministério da Justiça

MMA Ministério do Meio Ambiente

MP Ministério do Planejamento, Orçamento e Gestão

MPF Ministério Público Federal

NEI Nova Economia Institucional

NFGC Necessidade de Financiamento do Governo Central

OCK Outros Despesas Correntes e de Capital

OGU Orçamento Geral da União

PAC Programa de Aceleração do Crescimento

PBC Political Budget Cycle

PLDO Projeto de Lei de Diretrizes Orçamentárias

PLOA Projeto de Lei Orçamentária Anual

RCL Receita Corrente Líquida

SIAFI Sistema Integrado de Administração Financeira

SIOP Sistema Integrado de Orçamento e Planejamento

SOF Secretaria de Orçamento Federal

STN Secretaria do Tesouro Nacional

UO Unidade Orçamentária 


\section{SUMÁRIO}

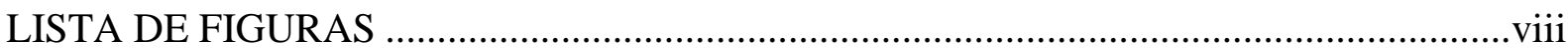

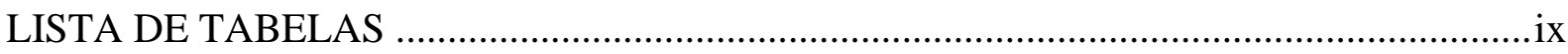

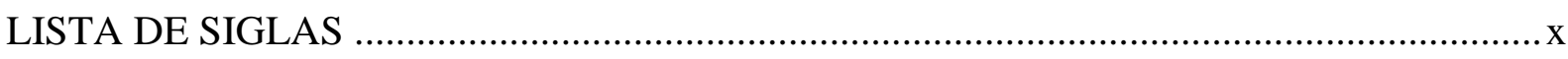

SUMÁRIO xi

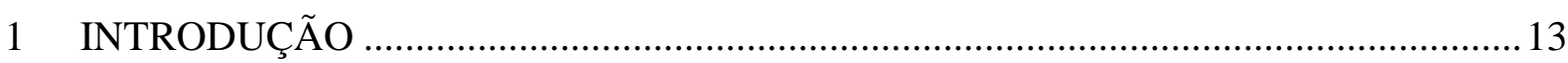

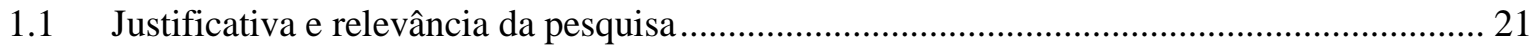

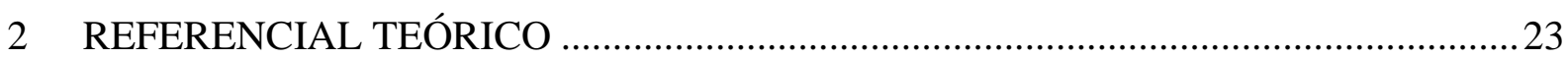

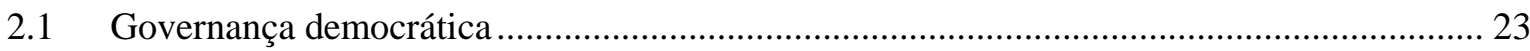

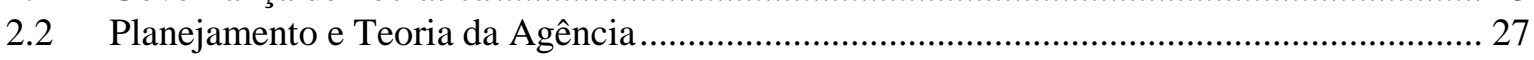

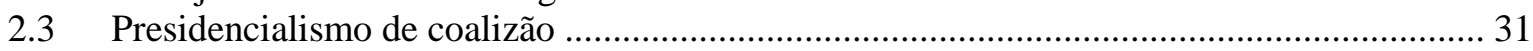

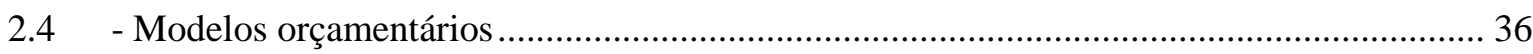

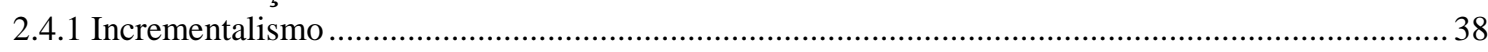

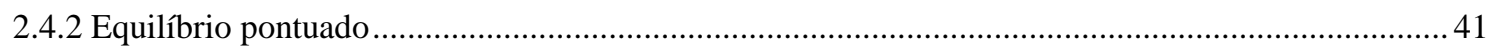

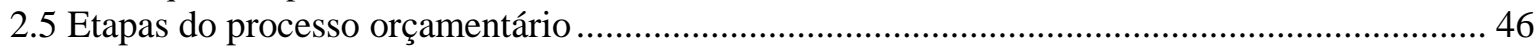

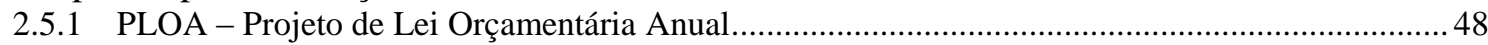

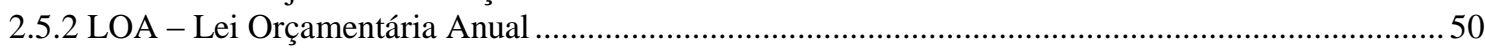

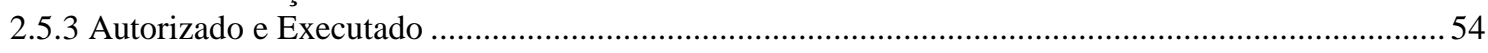

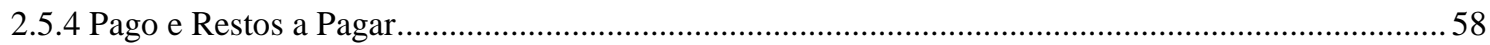

2.6 Ciclo político do processo orçamentário - Political Budget Cycle ............................................. 58

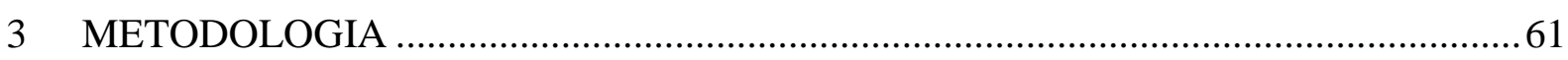

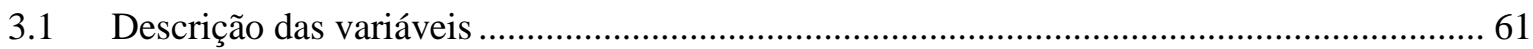

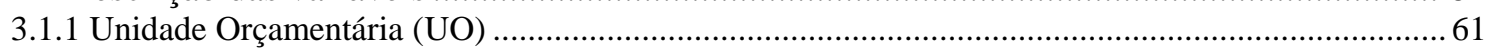

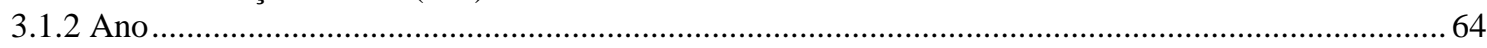

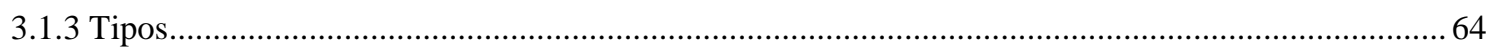

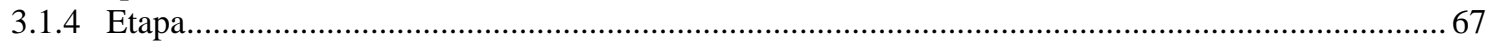

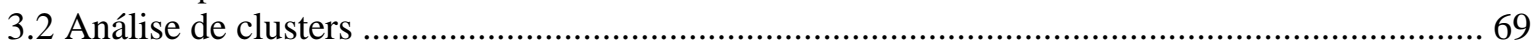

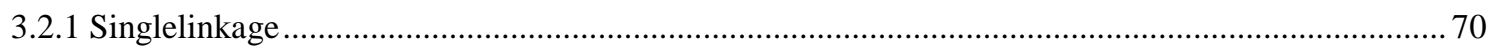

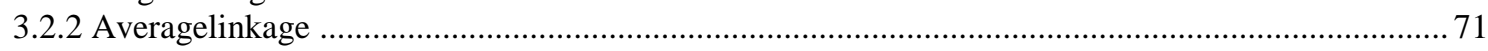

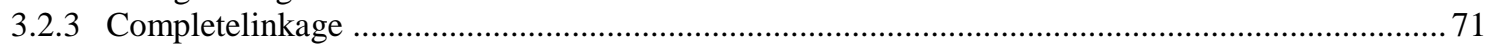

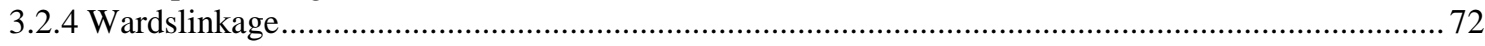

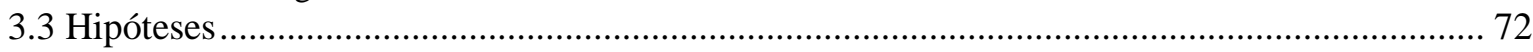

3.3.1 Hipótese 1 - tipos: Emendas individuais > grupo investimentos > grupo outros custeios e capital >

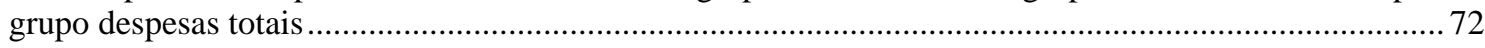

3.3.2 Hipótese 2 - ano: anos pares > anos ímpares.................................................................................. 73

3.3.3 Hipótese 3 - tipo unidade orçamentária: administração indireta > administração direta> fundos

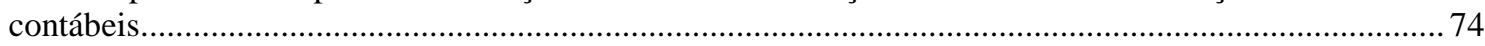

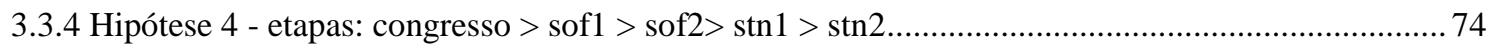

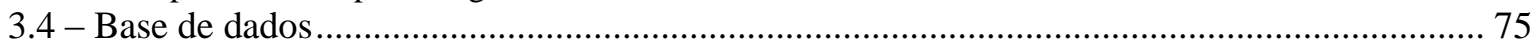

4 DESCRIÇÃO E ANÁLISE DOS DADOS .................................................................. 76

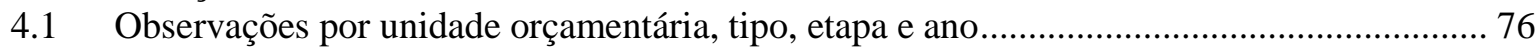

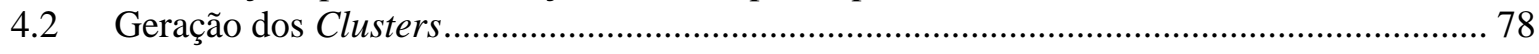

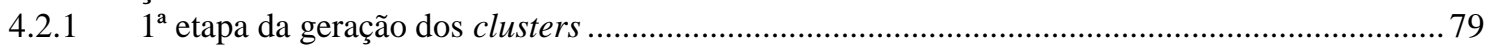

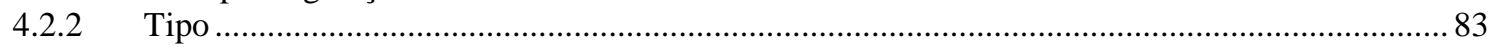

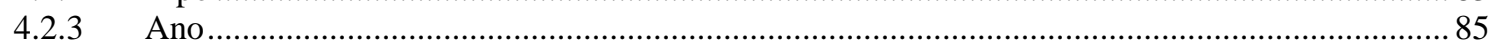

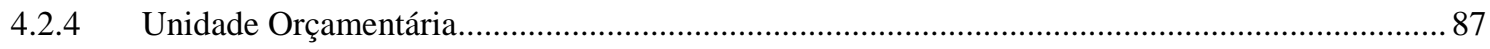

4.2.5 Resultados da geração dos clusters ...................................................................................... 94

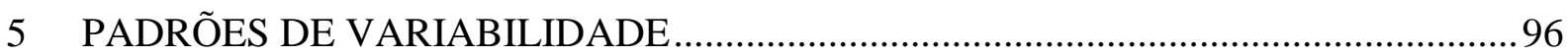

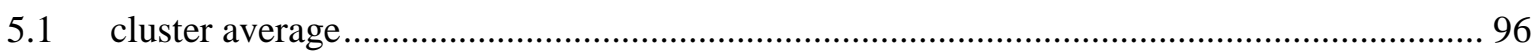

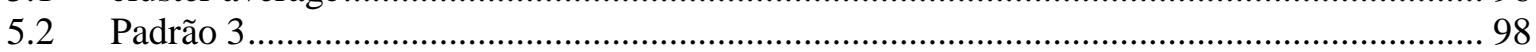

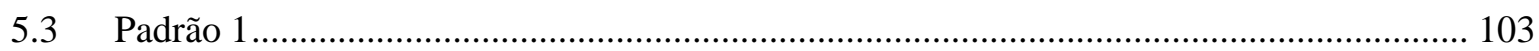




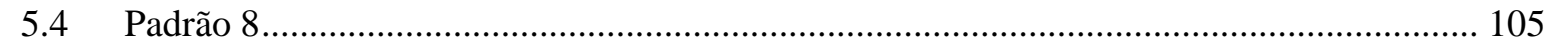

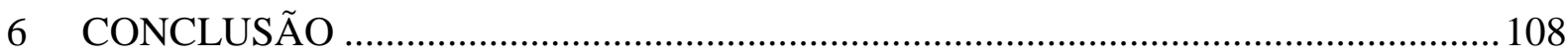

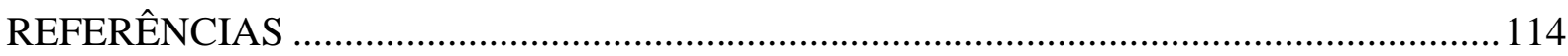

APÊNDICE A - Unidades orçamentárias por órgão - 2012 ............................................. 118

APÊNDICE B - Evolução temporal dos tipos de unidades orçamentárias............................. 119 


\section{INTRODUÇÃO}

Os orçamentos públicos são uma importante fonte de identificação e verificação dos comportamentos dos atores políticos em uma sociedade (WILDAVSKY, 1961). Quantificam as decisões políticas coletivas, levando em consideração disponibilidades de recursos, preferências dos atores responsáveis pelas decisões e estruturas por intermédio das quais essas decisões são tomadas (JONES; BAUMGARTNER; BREUNIG, 2009).

As mudanças orçamentárias costumam seguir determinados padrões, sendo que o orçamento público comporta-se, na maior parte do tempo, de forma incrementalista, entendida como aumentos pequenos e regulares, esporadicamente pontuadas por mudanças mais acentuadas (DAVIS; DEMPSTER; WILDAVSKY, 1966).

Outra percepção, buscando melhor compreensão do orçamento público, descreveo como um processo político decorrente das condições econômicas e sociais (DAVIS; DEMPSTER E WILDAVSKY, 1974). Em uma revisão dos ensinamentos de Wildavsky, é destacada sua percepção da profundidade dos laços entre o processo e a atividade políticos, tratando o orçamento público como decorrente da política (BARCELOS, 2008).

Nesse diapasão, entender o orçamento significa compreender as regras pelas quais a convivência em uma cultura é estabelecida. Em decorrência da alocação de recursos limitados, ante demandas ilimitadas, o conflito será gerado, porém as decisões serão tomadas mediante os consensos estabelecidos entre os atores do processo orçamentário.

Em outra abordagem, sobre o contexto orçamentário norte-americano (LELOUP, 2002), são destacadas as alterações que ocorreram, ao longo dos últimos anos, implicando em mudanças das estratégias dos atores envolvidos e das suas regras. Essas mudanças permitiram tornar o processo mais aberto, sem constitui-lo em uma peça acabada, a partir de sua proposição pelo Poder Executivo, mas em uma extensão da mesa de negociação, 
na qual diversos conflitos estão colocados, tendo as restrições fiscais tornado o orçamento um processo central de ajustamento de preferências coletivas frente a tais limites.

Em seu conteúdo, o orçamento contém as despesas e receitas do Poder Público, tornando-se o meio exclusivo para a autorização da utilização de recursos públicos de acordo com a programação aprovada (GIACOMONI, 2010). No caso brasileiro, de acordo com a Lei no 4.320, de 1964, a periodicidade prevista é a anualidade orçamentária, coincidente com o ano civil. Além dessa temporalidade, o orçamento público observa um devido processo legislativo, que tem início, na sua proposição, pelo Poder Executivo, e segue com a aprovação pelo Poder Legislativo.

Dadas as características do orçamento público, destaca-se sua importância, como instrumento para a coordenação das políticas públicas, e para o desenvolvimento e desempenho das ações governamentais, inclusive a manutenção de suas atividades básicas. Essa percepção é confirmada, pelo previsto, no art. 167, inciso I, da Constituição Federal, o qual estabelece a vedação ao início de programas e projetos não incluídos nas leis orçamentárias anuais.

Dessa forma, a manutenção e a conclusão dos diversos acordos políticos dependem de recursos públicos, os quais ficam condicionados pela previsibilidade orçamentária anual. Essa previsibilidade deriva do processo orçamentário, que se inicia com a elaboração da proposta orçamentária apresentada pelo Poder Executivo ao Poder Legislativo, e, após a aprovação, a execução orçamentária e financeira, em todos os seus estágios.

As expectativas, os propósitos e as capacidades de influenciar as decisões dos atores envolvidos condicionam as variabilidades de expectativas associadas a cada transação, a partir das sistemáticas envolvidas e dos contextos políticos no qual estão inseridos. Os relacionamentos envolvidos tratam do cumprimento dos acordos 
estabelecimentos, podendo ocorrer distorções entre o estabelecido e o seu efetivo cumprimento, como definido na teoria do Principal- Agente (JENSEN; MECKLING, 1976), no qual os principais, aqueles que delegam aos agentes a execução de tarefas, podem enfrentar desvios em suas finalidades e propósitos.

Os recursos previstos anualmente nos orçamentos podem variar de acordo com os atores e interesses (DAVIS; DEMPSTER E WILDAVSKY, 1974). Essa variância, conforme o grau de sua ocorrência e instabilidade, pode identificar a capacidade da manutenção dos acordos e contratos já estabelecidos, determinando o seu grau de incerteza.

As etapas da despesa pública comportam diferentes momentos passíveis de mudança na composição dos gastos públicos. Podem ocorrer diferenças significativas em seus diversos momentos (PEREIRA; MUELLER, 2002), tais como, o projeto de lei apresentado pelo Poder Executivo - PLOA, a lei orçamentária aprovada pelo Poder Legislativo e sancionada e publicada pelo Poder Executivo - LOA e os valores autorizados, executados (liquidados) ou pagos no exercício ou decorrentes de restos a pagar.

A análise das variâncias, ao longo do devido processo legislativo orçamentário, desde o encaminhamento do PLOA, até o pagamento dos valores autorizados, pode caracterizar interferências no processo orçamentário (FIGUEIREDO; LIMONGI, 2005). Essas interferências, variações ou fricções decorrem da mutação dos acordos, decorrente ou não de fatores exógenos (JONES; BAUMGARTNER, 2012), que aplicados ao caso brasileiro, teríamos as etapas inicialmente estabelecidos, no PLOA, alterados, na aprovação da LOA, no reajuste das autorizações de gastos, ao longo do exercício, e, novamente, na execução das dotações aprovadas ou no seu pagamento. As interferências podem ser decorrentes da diferença entre as vontades dos planejadores e mandatários e 
os executores, fato que caracteriza a dominância alternada entre as etapas, sob a ótica da teoria do Principal-Agente (LERUTH; PAUL, 2006).

Entre os fatores que influenciam a previsibilidade e a variância orçamentária podem ser destacadas o regime político, doravante mencionado como presidencialismo de coalizão (ABRANCHES, 1988) e eventos esporádicos, como os ciclos eleitorais, os quais podem acarretar alterações nos padrões estabelecidos. Além das variâncias totais, pertinentes aos orçamentos de cada órgão ou entidade, é importante distinguir outras formas de variância comumente empregadas nas pesquisas relacionadas ao presidencialismo de coalizão brasileiro. Nesse sentido, aparecem os gastos referentes aos custeios, aos investimentos e às emendas parlamentares.

Em estudo abordando a política orçamentária no presidencialismo de coalizão (FIGUEIREDO; LIMONGI, 2008), foi identificada a percepção de que a troca de apoio legislativo por liberação de verbas orçamentárias pressupõe a existência de diferentes agendas entre os Poderes Legislativo e Executivo, ocorrendo, nesse caso, uma assimetria entre esses atores. Assim a manutenção da coalizão dependeria dessas liberações.

As despesas de execução obrigatória, devido à imposição de obrigação constitucional ou legal na sua execução, têm natureza diversa daquelas chamadas discricionárias, não compulsórias, que guardariam maior relação com o cumprimento de acordos contingenciais e podem apresentar maiores oscilações, tanto durante o processo anual, como ao longo dos exercícios. Tais obrigações, em geral, focalizam os gastos correntes, mas não os gastos de capital. Assim, esses últimos são empregados em conjunto com os gastos correntes e como indicadores distintos das agendas específicas de cada período administrativo.

Ademais, as emendas parlamentares individuais podem ser vistas como a tentativa de inserção de acordos diferenciados no processamento do gasto público. Enquanto a 
iniciativa da deliberação orçamentária cabe ao Poder Executivo, as emendas individuais marcam as agendas específicas de cada congressista e servem de instrumento de barganha, na obtenção de apoio político às agendas executivas (PEREIRA; MUELLER, 2002).

Outro modelo que retrata a variância orçamentária é o do equilíbrio pontuado, no qual a associação da alocação de recursos às mudanças políticas com impacto, no processo orçamentário, acarretam alterações pontuais de características incrementais ou não (JONES; BAUMGARTNER, 2012). As mudanças ocorrem, continuamente, não apenas em situações previsíveis, como eleições ou pressões da opinião pública, apesar dos momentos de estabilidade. Momentos curtos de mudanças, em um ambiente instável, estão inseridos entre longos períodos nos quais predomina a estabilidade previsível. As decisões dos atores políticos consideram a racionalidade limitada e o cálculo de custos e benefícios transacionais envolvidos nas tomadas de posições, inclusive relacionadas às escolhas e aos gastos públicos.

Essa relação intrínseca com a política não se aparta do estudo orçamentário. Nesse sentido, o orçamento constitui um instrumento útil, para a análise da política, isto é, para a identificação de quem ganha o que, porque motivo e que diferença isso faz (LASSWELL, 1936). Assim, o orçamento representa ganhadores e perdedores e os resultados dos acordos realizados na solução de conflitos, em face da necessidade de escolhas públicas e do dissenso decorrente da definição das prioridades que deverão ser atendidas no orçamento.

Nesse contexto, cabe ao sistema político determinar quem terá prioridade e, portanto, menor exposição à incerteza de gastos públicos, e quem não terá essa prioridade e lidará com graus mais elevados de incerteza (JONES; BAUMGARTNER, 2012). Assim, pode ser examinada a alocação anual de recursos públicos como uma variável de 
risco, que pode interferir em diversas características da administração pública federal, assim como nas escolhas dos demais agentes sociais, tendo em vista o grau de certeza e estabilidade da manutenção dos acordos políticos expressos pelas escolhas orçamentárias. A correspondência desses riscos com os custos transacionais considera a contratualização e a precificação dos primeiros nos acordos políticos.

De modo similar, o entendimento da variabilidade orçamentária é útil, na correlação com os indicadores de governança, a exemplo dos considerados, como em trabalho (BERSCH; PRAÇA; TAYLOR, 2013) que investigou a relação, entre autonomia, capacidade operacional, corrupção, politicização e resultados de órgãos e entidades da administração pública federal. As correlações entre as variáveis estudadas permitem a realização de inferências, a partir dos vínculos existentes, entre as variáveis do estudo, e retratam a face dinâmica do setor público relacionada à governança.

Assim, a verificação das relações entre as variâncias orçamentárias e as variáveis tratadas, nos trabalhos anteriores (BERSCH; PRAÇA; TAYLOR, 2013), revelaria se tal variância, verdadeiramente, constitui uma proxy razoável, para também servir como indicador da qualidade da governança. Desse modo, no intuito de verificar a pertinência do orçamento público como instrumento de planejamento, a presente pesquisa pretende verificar os tipos e as características das variabilidades orçamentárias, entendendo o comportamento dos atores por meio do olhar sobre o processo orçamentário.

Os custos transacionais do presidencialismo de coalizão seriam baixos (MUELLER; PEREIRA, 2002), o que pode ser corroborado ou contestado nesta pesquisa. Nesse diapasão, as correspondências existentes, entre as diferentes arenas políticas do presidencialismo de coalizão, e a importância dos critérios adotados, pelas alocações orçamentárias, na dinâmica da administração pública federal, também subsidiam a verificação da expectativa de que as alocações efetuadas em gastos discricionários, ou 
seja, principalmente em investimentos, e emendas parlamentares individuais, estejam associadas a menores autonomia institucional, capacidade e desempenho operacionais, além de maiores incidência de casos de corrupção e interferência política em órgãos e entidades federais.

O termo instituições, nesta pesquisa, remete às organizações formadas pelas pessoas e às regras de convívio social. No parágrafo anterior, esse termo foi empregado com o primeiro sentido. No parágrafo a seguir, será usado conforme a segunda possibilidade. Assim, o contexto do termo indica o significado específico atribuído ao longo da pesquisa.

A corrupção não decorre diretamente das fragilidades de caráter das pessoas, mas de fragilidades institucionais, que não inibem os atos impróprios (ALVES; SODRÉ, 2007). Eles observam ainda relações entre emendas parlamentares ao orçamento e corrupção. Sobre o presidencialismo de coalizão, na lente dos custos transacionais, é constatado que o gasto orçamentário, particularmente no que se refere à execução das emendas parlamentares individuais, expressam o meio de o Poder Executivo assegurar sua governabilidade, tendo em vista as coalizões partidárias que a sustentam (PEREIRA; MUELLER, 2002).

Em retrospecto sobre o impacto do ciclo eleitoral nos processos orçamentários (BARBERIA; AVELINO, 2011), foram destacados que os governos manipulam a política fiscal, para obterem sucesso eleitoral, e que, observando, principalmente, os chamados países menos desenvolvidos, o nível de gasto governamental cresce nos períodos préeleitorais, e apresentam redução nos períodos pós-eleitorais. Assim, entre os anos pré e pós eleitorais há a expectativa da verificação de uma maior variabilidade, lembrando que os períodos pré-eleitorais são coincidentes com os anos pares. 
Esse trabalho pretende confirmar esses comportamentos tipificados pela variabilidade orçamentária relacionada à manutenção dos acordos no decorrer dos exercícios, entre determinados grupos de despesas e certos grupos institucionais, identificados no orçamento pelas unidades orçamentárias. Assim, a compreensão das alterações ao longo do processo possibilitará constatar a efetividade do planejamento público refletido na execução orçamentária, fato questionado no âmbito da Administração Pública Federal (GRAU, 2012; PEDERIVA; LUSTOSA, 2007). Para verificação e análise da identificação de padrões de mudança e variação no orçamento público, será aplicada a análise de cluster, que se constitui em um novo instrumento para confirmar as indicações dos estudos orçamentários.

Desse modo, cabe a seguinte questão: o orçamento público é uma peça de planejamento em relação às expectativas de realização dos gastos ali delineados? Assim, o objetivo geral desta pesquisa consiste em avaliar características e tipos das variabilidades orçamentárias, à luz dos modelos orçamentários.

A partir do objetivo geral, a pesquisa tem os seguintes objetivos específicos:

a) descrever as variações, classificações e entidades integrantes do Orçamento Federal;

b) identificar os grupos de unidades orçamentárias que possuem padrões similares de variabilidade;

c) verificar se a variabilidade orçamentária apresenta comportamento diverso, de acordo com os tipos de despesas, gastos por unidade orçamentária, gastos de custeio e investimento, investimentos e emendas parlamentares individuais no decorrer do processo orçamentário; 
d) analisar os agrupamentos de despesa como alternativa aos métodos utilizados, na abordagem, sobre o orçamento público, para identificar o grau de realização das expectativas de gastos federais orçamentários e comportamento do processo orçamentário; e

e) verificar, caso possível, se as variáveis orçamentárias podem servir como indicadores de riscos regulatórios, a partir de indicadores de governança.

\subsection{Justificativa e relevância da pesquisa}

O orçamento público tem sido criticado, em diversas ocasiões, pelo não cumprimento do seu papel de instrumento de planejamento (GRAU, 2012). Isso decorre do fato de que diversos recursos alocados, nas leis orçamentárias, acabam não sendo realizados, ou seja, o gasto previsto e aprovado não é executado (PEREIRA; MUELLER, 2002). Tal frustração impõe a percepção de que diversas políticas planejadas acabam não sendo implementadas, devido aos entraves e às características discricionárias ou meramente autorizativa do orçamento.

O entendimento do comportamento do orçamento e sua dinâmica revestem-se, nesse contexto, de uma percepção essencial no aprimoramento e efetividade das políticas

públicas. É preciso que os estudos comprovem e descrevam as formas e maneiras com que os atores interagem no processo orçamentário. A verificação de padrões de comportamento possibilitará identificar a simetria das ações entre as unidades orçamentárias federais.

Assim, a incorporação de novas metodologias de análise do processo orçamentário, considerando a previsibilidade de recursos, poderá contribuir, também, para a descoberta de novos meios e instrumentos no intento de assegurar determinados 
padrões de comportamento e evitar outros. Tal determinação reflete, positivamente, na qualidade da governança, da compreensão do comportamento do orçamento público e da capacidade de justificação das escolhas públicas em face das demandas por recursos escassos.

Dessa forma, a utilização da análise de cluster, para tentar identificar padrões e grupos, com relação à previsibilidade financeira no orçamento público, pode se revelar como instrumento inovador para análise do orçamento público. Acrescenta-se, então, um novo instrumento analítico, para contribuir na melhoria da efetividade das políticas públicas, por intermédio do aperfeiçoamento do processo orçamentário. 


\section{REFERENCIAL TEÓRICO}

\subsection{Governança democrática}

$\mathrm{O}$ orçamento constitui uma peça fundamental e essencial das políticas públicas. Segundo o Decreto-lei nº 200, de 1967, ele é um dos instrumentos básicos do planejamento. Para a sua consecução, deve-se agregar um Estado com capacidade e em condições operativas que permitam a materialização dos objetivos constantes dos planejamentos públicos. Em outras palavras, o orçamento também é um guia da atuação governamental e um instrumento de controle dos agentes públicos.

Fukuyama (2006) chama de governança a caracterização, que trata da capacidade de o Estado entregar os serviços e obras, abordando a execução das aspirações da sociedade por meio dos governantes. A governança, na percepção do autor, não depende do tipo de regime, se autoritário ou democrático, focando, simplesmente, na execução, entrega e disponibilização do serviço; que para sua avaliação podem ser utilizadas pelo menos três critérios de mensuração: processos, capacidade e resultados.

A governança também é mencionada como um conjunto adequado de práticas democráticas e de gestão, que colaboram na melhoria das condições de desenvolvimento econômico e social de um país (SECCHI, 2009). Destaca-se, ainda, que o Fundo Monetário Internacional - FMI adota a condição de boa governança como condição essencial para a prestação de apoios financeiro e técnico aos países demandantes. A governança é entendida como o modelo horizontal de relação, entre atores públicos e privados, na elaboração de políticas públicas (SECCHI, 2009), denotando pluralismo e está associada ao neoliberalismo.

Para avaliar a capacidade do Estado e a autonomia das instituições, na Administração Pública Federal, é vital analisar a capacidade do Estado e desenvolver 
formas alternativas de mensuração das relações entre sua capacidade e desenvolvimento político e econômico ao redor do mundo (BERSCH; PRAÇA; TAYLOR, 2013). Assim, foram realizadas avaliações sobre a autonomia, a capacidade institucional e a corrupção, em entidades do setor público, e verificadas as suas correlações (BERSCH; PRAÇA; TAYLOR, 2013).

Os autores mencionam a forma com que o Brasil, em sua exemplificação, atingiu o crescimento econômico e o desenvolvimento industrial, a despeito de a capacidade geral da sua burocracia estatal ser classificada como mediana. Contudo, eles ressalvam a importância da excelência, em alguns setores, aos quais foram concedidas condições específicas, como a proteção contra pressões de atores interessados e o suporte orçamentário, que permitiram uma atuação efetiva, assegurando o alcance dos resultados desejados.

O estudo observa como a capacidade de o Estado implantar de forma eficaz e eficiente as políticas públicas pode apresentar grande variação conforme os setores envolvidos. Assim, é possível verificar que alguns governos podem ser muito bons, na capacidade de arrecadar recursos públicos, e, simultaneamente, serem ruins, na implementação de políticas de garantia do bem-estar social, devido à burocracia excessiva, interferência política e corrupção em diversos níveis (BERSCH; PRAÇA; TAYLOR, 2013).

Nesse contexto, ainda observam que a medição da capacidade estatal e o conhecimento da real capacidade de determinados setores e agências, principalmente no Brasil, demonstra a coexistência de setores com baixa e alta capacidade, entendida como a qualificação do seu corpo de servidores; além de entidades que atuam com clara autonomia, contra práticas clientelistas e influências negativas do sistema político, e outras que sofrem grande influência e interferência de agentes externos. 
A democracia não impediu a manutenção dessa tendência dual (BERSCH; PRAÇA; TAYLOR, 2013), a qual acarretou diversos escândalos públicos nos últimos anos, tendo sido acentuado pelo sistema prevalente, denominado de presidencialismo de coalizão (ABRANCHES, 1988). Os resultados encontrados por eles apontaram relações significativas, entre autonomia e capacidade e corrupção, em que maiores autonomia e capacidade estatal estão relacionadas com menores índices de corrupção, mensurados a partir dos escândalos publicados na mídia, no decorrer do período do estudo, de 2002 a 2012, e das demissões ocorridas a bem do serviço público. Outra constatação é que o aumento da autonomia institucional em um desvio-padrão estaria associado à uma redução de 43\% das demissões; porém, não foi encontrada relação entre melhoria da capacidade institucional e variações nas demissões constatadas.

A corrupção, no contexto da governança do setor público federal brasileiro, também foi objeto de estudo, a partir da percepção de que a corrupção no Brasil é decorrente de falhas institucionais, incapazes de inibir essas práticas impróprias, eles observaram forte relação da execução das emendas parlamentares ao orçamento e corrupção em municípios brasileiros (ALVES; SODRÉ, 2007). Nesse sentido, os municípios beneficiados por emendas parlamentares seriam em média 35\% mais corruptos do que os demais, de acordo com a verificação dos autores.

Destacando as relações entre a politicização do serviço público brasileiro, a capacidade do Estado e o alcance de resultados, entendido como indicador de sua governança, foi concluido que, quanto maior a politicização, ou seja, o preenchimento de cargos por critérios políticos, menor a capacidade estatal (BERSCH; PRAÇA; TAYLOR, 2013), além da identificação de forte e positiva relação entre capacidade estatal e resultados obtidos pelo setor público. 
Quando o processo orçamentário está centralizado, há melhores condições para a imposição de restrições orçamentárias (BORGE; FALCH; TOVMO, 2008), reduzindo as influências das agências que ofertam os serviços, forçando-as a serem mais eficientes. Nessa situação pressupõe-se que as instituições ficariam menos sujeitas às variabilidades orçamentárias. Quanto à capacidade fiscal, verificaram que a boa capacidade de extrair os recursos da população pode levar à obtenção de superávits e à realização tranquila dos serviços, afastando preocupações de melhoria da eficiência. A maior deliberação popular tende a levar um alto comparecimento às urnas e incentiva políticas que visem à eficiência no serviço público. A maior transparência, nos resultados da atividade política, incentiva à economia de recursos, utilizados em proveito das variadas demandas apresentadas pela sociedade (BORGE; FALCH; TOVMO, 2008).

A relação entre fragmentação partidária e eficiência, na oferta de serviços públicos, caracteriza o contexto de governos de coalizões, cujos custos de transação para a manutenção dos acordos que viabilizam as coalizões são fatores impeditivos da melhoria da eficiência. Observações em doze países da União Europeia verificaram que, mantidas sob controle as variáveis institucionais, políticas e econômicas, quanto mais rígidas as regras orçamentárias, maior a redução de desequilíbrios fiscais e menor o tamanho do orçamento, isto é, o volume de recursos extraído da sociedade (LAGONA; PADOVANO, 2007).

A boa governança é um pré-requisito essencial para se alcançar um desenvolvimento econômico sustentável (HOPE, 2009). Nesse propósito, o desenvolvimento da boa governança está relacionado à necessidade do desenvolvimento das capacidades relacionadas também com as competências dos indivíduos e das instituições públicas e privadas, e a realização de determinados objetivos, como a redução da pobreza, o crescimento econômico, a oferta de serviços eficientes e os demais desafios 
decorrentes da globalização. Assim, o desenvolvimento das capacidades resulta do aprimoramento dos atores sociais envolvidos, nas mais diversas áreas, para assegurar o cumprimento dos objetivos de interesse da sociedade.

A definição de boa governança considera a existência, dentro do Estado, de responsabilização das ações, transparência burocrática, exercício legítimo do poder, liberdade de associação, informação e expressão, estabilidade fiscal, respeito às leis, sistema judiciário confiável, respeito pelos direitos humanos, atividade legislativa, oportunidades para o desenvolvimento das forças plurais e desenvolvimento das capacidades.

\subsection{Planejamento e Teoria da Agência}

O planejamento na Administração Federal é um dos princípios fundamentais previstos para suas atividades, conforme estabelecido no Decreto-Lei no 200, de 1967. Esse princípio tem como objetivo promover o desenvolvimento econômico e social, norteando-o segundo planos e programas gerais, setoriais e regionais, incluindo os orçamentos e as programações financeiras de desembolso.

Como instrumento norteador da ação governamental, o planejamento no setor público possui algumas características, entre as quais o fator determinante para o setor governamental (PEDERIVA; LUSTOSA, 2007). Contraponto ao setor privado, no qual o planejamento é apenas indicativo. Assim, toda atividade estatal deveria ser decorrente de uma ação planejada, restringindo-se o improviso.

Na perspectiva constitucional, o planejamento qualifica a intervenção no domínio econômico, dotando-a de uma racionalidade, revertendo uma situação na qual as decisões 
que anteriormente eram tomadas de forma aleatória, ad hoc, passam a ser conduzidas de forma sistemática, seguindo um padrão de racionalidade (GRAU, 2012).

Na Lei de Responsabilidade Fiscal - LRF, o orçamento público integra o capítulo que trata do planejamento, o que faz supor que a LOA deve ser um instrumento de planejamento do setor público. Fato que reforça esse papel, é a previsão da Lei 4.320, de 1964, que trata a Lei de Orçamento como aquela que conterá a discriminação da receita e da despesa de forma a evidenciar a política econômica e financeira e o programa de trabalho do Governo.

Nesse contexto, seria razoável entendermos as leis orçamentárias como quantificações planejadas da intervenção do setor público, carregando sua previsibilidade uma coerência com seu status de instrumento racional de planejamento, com vistas a assegurar uma boa governança. Quando instrumentalizado como meio de planejamento para o alcance dos objetivos pretendidos na política econômica e social de um país, as leis orçamentárias deveriam supostamente ter pouco espaço para decisões ad hoc, apresentando ao longo do processo orçamentário uma estabilidade linear, com ajustes limitados. Dessa forma, ajustes ao final do processo seriam residuais.

Nesse ponto, a compreensão das variabilidades orçamentárias poderá ajudar a entender em que medida o orçamento é efetivamente uma peça de planejamento, e também para refletir como as decisões ocorrem, quais os atores envolvidos e fatores presentes no processo decisório orçamentário.

O processo orçamentário é constituído de várias etapas nas quais diversos atores estão presentes, seja nas decisões ou nas execuções, e sujeitos a interferências, alterando eventualmente o resultado final. Nesse ponto, a compreensão e aplicação da teoria do Principal-Agente será útil para ajudar a compreender as relações entre os atores 
envolvidos no processo orçamentário e as variabilidades orçamentárias, e entender as alterações no planejamento orçamentário.

A teoria do Principal-Agente trata da relação na qual determinadas pessoas, uma ou mais, chamadas de principal ou principais, delegam as responsabilidades pela execução de determinada tarefa ou representação a outra pessoa, chamada de agente, definida por meio de um contrato formal ou informal (JENSEN; MECKLING, 1976).

Considera-se que a teoria do Principal-Agente busca abordar algumas situações envolvendo o relacionamento entre as partes, primeiramente quando os desejos e objetivos do agente e dos principais são conflitantes; e a busca na verificação da dificuldade e custo no controle pelo principal das ações do agente, chamado de custo de agência; e a segunda pelas diferentes propensões a riscos, o que levaria a diferentes atitudes em uma mesma situação (EISENHARDT, 1989)

A teoria do Principal-Agente tem sido utilizada no entendimento de determinadas situações, como corrupção e má governança, a partir da assimetria de informações e interesses divergentes presentes na relação entre quem executa as tarefas, os agentes, e aqueles que estabelecem as tarefas a serem desempenhadas, os principais (LERUTH; PAUL, 2006).

A utilidade da teoria do Principal-Agente, considerada contratualista, foi verificada nas escolhas públicas no PPA 2008-2011 (COSTA; FREIRE; GARTNER; CLEMENTE, 2013), na avaliação do comportamento dos gestores até o resultado final das organizações públicas. Em sua aplicação entre o setor privado e o setor público, a diferença é que, no primeiro, o agente está ligado somente a um principal ou número reduzido, e no segundo, o agente está ligado a vários principais, tomando como exemplo as eleições, nas quais, os eleitores concedem poderes de representação a determinados agentes. 
Em estudo sobre a gestão dos gastos públicos sob a ótica da teoria do PrincipalAgente (LERUTH; PAUL, 2006), foi colocado que, conforme a situação, diversos atores podem funcionar como principal e agente. Tomando como exemplo, citam caso em que o Ministro de Finanças atua como principal quando transfere recursos para os demais ministérios, os agentes, executarem suas políticas. Os ministérios atuariam como principais quando passam a incumbência da realização da tarefa de implementar suas políticas para os seus servidores, os agentes. Outra forma de enxergar essa relação seria, também, a transferência dos governos centrais, o principal, para os subnacionais, os agentes (LERUTH; PAUL, 2006). Essas relações podem ser analisadas sob o olhar dos custos de agência, da assimetria de informações e de diferenças propensões ao compartilhamento dos custos.

Forrester (2002) abordou a perspectiva do agente e do principal no processo orçamentário, considerando que os que demandam recursos públicos são os agentes, e os que alocam e até racionam esses recursos são os principais. Nessa relação, os principais contratam os agentes para prover os serviços públicos e o foco está no contrato, que neste caso é o orçamento. Lembra, também, que na perspectiva dessa teoria as informações são geridas pelas partes no intuito de alcançar seus interesses próprios, maximizando suas utilidades.

Conforme a entidade que melhor controla a informação e, também, ao tipo de relação hierárquica que é estabelecida, podemos ter uma dominância no processo e relação Principal-Agente, que conforme a parte que prevalece, chamado de domínio do agente, ou no caso do orçamento público, de domínio do legislativo ou domínio do executivo (FORRESTER, 2002). Essa abordagem pode ser útil para compreender as etapas do processo orçamentário, nas quais aparentemente existe uma busca na 
prevalência de interesses, conforme análises sobre a etapa legislativa orçamentária (FIGUEIREDO; LIMONGI, 2008).

Dessa forma, as relações verificadas no orçamento público podem ser estudadas e compreendidas por meio da teoria do Principal-Agente, cujos domínios das partes irá depender do controle da informação e da relação hierárquica estabelecida (FORRESTER, 2002).

As dificuldades verificadas em organismos internacionais devido aos problemas decorrentes da relação Principal-Agente enfocam os custos de informações elevados e incentivos fracos ou distorcidos (VAUBEL, 2006). Outro aspecto colocado é que o problema Principal-Agente é maior em grandes organizações, como os governos centrais.

Desse modo, a teoria do Principal-Agente pode ter uma consistente aplicabilidade ao setor público, compreendido como uma grande organização. Assim, os problemas de agenciamento podem surgir em diversas etapas e segmentos do processo político, incluindo o orçamentário.

\subsection{Presidencialismo de coalizão}

O presidencialismo de coalizão destaca-se como o regime político brasileiro decorrente da heterogeneidade da sociedade brasileira (ABRANCHES, 1988). No contexto macroeconômico, essa heterogeneidade aparece como desigualdades na distribuição de renda, diferenças técnicas e culturais entre pessoas, empresas e setores, e disparidades entre as regiões, com demandas diferenciadas, conforme características regionais e locais do País.

Essa pluralidade revela diferenciadas demandas e expectativas, em relação ao setor público (ABRANCHES, 1988), caracterizado pela acumulação de privilégios, pelo desequilíbrio permanente, entre as fontes de receita e as demandas de gastos, bem como 
no intenso conflito, sobre as alocações dos recursos públicos, lembrando que a multiplicação de demandas acentua a tendência histórica de ampliação da atuação estatal.

Esse conflito pode ser verificado, nas relações entre o Poder Executivo e o Poder Legislativo, demonstrando-se um elemento crítico para a estabilidade econômica devido às grandes fragmentações na composição das forças políticas e agenda inflacionada de problemas e demandas; o que culmina, em maior ou menor grau, em descontinuidades e desajustes, entre a composição das forças que promovem a ordem institucional (ABRANCHES, 1988). Para sua manutenção, tais forças requerem diversos acordos, cuja característica marcante é a instabilidade, devido à transitoriedade da sua composição.

Ainda em relação a essa instabilidade, a constituição de coalizões viabiliza o pacto político, em prol da governabilidade, porém sobrecarrega a pauta de decisões com temas conflitivos e não negociados (PEREIRA; MUELLER, 2002), exigindo um esforço de construção institucional, para viabilizar os acordos e solucionar os problemas que emergem dessa relação.

Abordando a política orçamentária no presidencialismo de coalizão (FIGUEIREDO; LIMONGI, 2008), observou-se que, a partir de uma participação anterior quase anárquica do Poder Legislativo, tem-se, atualmente, um regramento, definindo a participação específica de cada parlamentar, com espaço maior para grupos e partidos políticos de maior influência e peso, que atuam de forma marcante, na alocação de recursos que cabe ao Poder Legislativo.

A característica da atuação do Poder Legislativo não difere das intenções indicadas, pelo Poder Executivo, na elaboração do PLOA, pois os programas temáticos objetos dos interesses são coincidentes (FIGUEIREDO; LIMONGI, 2008). As diferenças estariam nas alocações mais acentuadas, pelo Poder Legislativo, de recursos ao nível municipal. Essa alocação predominante ao nível municipal é descrita como paroquialista. 
A participação do Poder Legislativo ocorre, não apenas no âmbito das discussões, perante o Congresso Nacional, mas também na definição da agenda do Poder Executivo, pois, em um presidencialismo de coalizão marcado por representação multipartidária, a agenda é resultado de barganha (FIGUEIREDO; LIMONGI, 2008. PEREIRA; MUELLER, 2004). Essa barganha abrange a ocupação de cargos, no Poder Executivo, pelos partidos políticos que compõem a coalizão, exercendo funções executivas, nos ministérios, o que acarreta conflito, entre os formuladores da agenda no Poder Executivo, com cada participante buscando a defesa dos interesses partidários e de grupos que representam.

É lógico que a participação de membros de partidos políticos, na definição da agenda do Poder Executivo, está reservada àqueles de maior prestígio, entendido como relevância e influência, na apreciação de matérias legislativas, cooperando com a aprovação das matérias, das propostas e dos intentos do Presidente da República e da sua base. As repercussões do presidencialismo de coalizão alcançam a definição de cargos estratégicos nas decisões orçamentárias (FIGUEIREDO; LIMONGI, 2008). No Poder Legislativo, tais cargos seriam o de Presidente da CMO e Relator-Geral da PLOA, posições que se alternam, entre os principais partidos de sustentação da coalizão, que, notadamente, ocupam a maioria dos cargos políticos no Poder Executivo. Nesse contexto de presidencialismo de coalizão, os Poderes Executivo e Legislativo se interpenetram na elaboração e na execução da política orçamentária.

O presidencialismo de coalizão é mencionado como associado a custos elevados, em comparação a governos formados por partidos majoritários (PEREIRA; MUELLER, 2002). Esse custo elevado decorre de clientelismo e fisiologismo em troca de apoio parlamentar. Dessa forma, os custos de transação, no processo político, são consideráveis, devido ao grande número de veto players, agentes com o poder de interferir no andamento 
das políticas. Tal situação é presente e constante no presidencialismo de coalizão. Para a implementação de decisões, é necessária a anuência de diversos agentes, de origem e interesses variados, ao longo do processo, desde a proposição até a execução de políticas públicas, com o efetivo pagamento dos correspondentes valores devidos.

O Brasil padece de quase todas as patologias institucionais responsáveis pela elevação do custo de governar, como sistema presidencialista, regras eleitorais que combinam lista aberta com representação proporcional, sistema multipartidário com partidos considerados débeis, em sua maioria, na arena política, e governos de coalizão no Congresso. Essas características podem levar à governabilidade dispendiosa, com elevados custos para manutenção da unidade e da disciplina de sua coalizão (PEREIRA; MUELLER, 2002).

Abordando os dados das liberações de recursos para execução das emendas parlamentares, particularmente as individuais, foi percebido que o sistema brasileiro de presidencialismo de coalizão permite ao Executivo adotar duas estratégicas; premiar os parlamentares que integram a coalizão ou punir os que dela não fazem parte (PEREIRA; MUELLER, 2002). Desse modo, a liberação da execução de emendas parlamentares leva em consideração o tamanho e a importância dos partidos políticos que integram a coalizão e a postura nas votações de assuntos de interesse do Executivo.

Quanto maior o valor das emendas parlamentares executadas de um congressista, maiores são suas chances de reeleição (PEREIRA; MUELLER, 2002). A execução de uma emenda é a oportunidade de demonstrar a realização de um objetivo em prol da população que representa ou até de grupos que colaboram em campanhas políticas. Pela sua importância para a carreira política do parlamentar, a demonstração da destinação de recursos, para locais e objetos do seu interesse, por meio da execução de emenda 
individual, pode significar a própria sobrevivência política, o que influencia a adesão à coalizão governista.

Dentre algumas características dos regimes de governo de coalizão e seus reflexos no orçamento, os compromissos entre motivações ideológicas diferentes, representadas em um sistema multipartidário, podem resultar em tendência a déficits orçamentários, mesmo que todos os partidos da coalizão desejem um orçamento equilibrado (BALASSONE; GIORDANO, 2001). Segundo as avaliações realizadas em países europeus, entre 1971 e 1990, a tendência ao déficit orçamentário aumenta o grau de polarização das motivações ideológicas e diminui o grau de concentração de poder dentro do governo.

Em governos de coalizão multipartidária, em governos europeus, verificou-se situações nas quais há a tendência a obscurecer a atuação de ministros que apresentam conflitos entre seus interesses próprios e dos parceiros da coalizão (CARROLL; COX, 2012). Esse fato caracteriza que, mesmo em governos de coalizão, a simples convivência não facilita a manutenção dos acordos realizados: é necessária a congruência com os parceiros que sustentam a coalizão.

Com relação aos benefícios de uma coalizão governista, membros do parlamento europeu formaram, voluntariamente, um grupo político coeso e votam juntos nas proposições do parlamento (HIX; NOURY; ROLAND, 2009). O comportamento intrigante, na percepção dos autores, objetiva aproveitar as vantagens de uma coalizão votando uniformemente em diversas situações.

Uma análise sobre o aumento de déficits orçamentários em governos de coalizões concluiu que o orçamento expressa mais as prioridades políticas do que as prioridades econômicas (FABRIZIO; MODY; CORSETTI; TEMPLE, 2006). As instituições orçamentárias, seus mecanismos e regras que definem o processo orçamentário, 
estabelecem controles e instrumento de equilíbrio que produzem valores significativos, na restrição a pressões fiscais, mesmo quando a política é representativa e indisciplinada e as forças estruturais de longo prazo são desfavoráveis.

Dessa forma, as coalizões são estabelecidas a partir de acordos, entre diferentes partes, que buscam condições para mútuo benefício. Tais condições são reveladas, por variáveis associadas à manutenção das expectativas. Assim, menor variância orçamentária indica maiores custos transacionais relativos, enquanto maior variabilidade orçamentária decorre de menores custos transacionais.

\section{4 - Modelos orçamentários}

A implementação de políticas públicas tem como objetivo atender ao anseio de demandas ou necessidades da sociedade. Assim, a partir das orientações previstas e aprovadas, nos planejamentos do setor público, são previstos recursos financeiros, nas leis orçamentárias anuais, para viabilizar as políticas públicas (GIACOMONI, 2010).

Os gastos do setor público brasileiro devem obrigatoriamente constar das leis orçamentárias anuais, conforme o princípio da universalidade, previsto na legislação brasileira, que prevê que devem constar das leis orçamentárias anuais todas as despesas e receitas do setor público (GIACOMONI, 2010). O orçamento público é, simultaneamente, instrumento político, econômico, contábil e administrativo (HYDE, 1992). Essa característica multifacetal e eclética do orçamento evidencia o alcance das decisões ali concretizadas e os interesses mobilizados pelo devido processo orçamentário.

O orçamento público como documento político, representa a alocação de escassos recursos, entre múltiplos e algumas vezes conflitantes interesses da sociedade (HYDE, 1992). Como documento fiscal e econômico, é o instrumento primário, para avaliar a 
distribuição das receitas, estimular o crescimento econômico, promover o pleno emprego, combater a inflação e manter a estabilidade econômica. A parte contábil revela os gastos governamentais e sua ligação com os fundos públicos; e a característica administrativa e gerencial é verificada, na especificação dos caminhos e meios com que ocorrerão a provisão dos serviços públicos, além dos critérios de monitoramento, acompanhamento e avaliação.

Acerca dessa caracterização do orçamento como instrumento eclético, no qual são identificados diversos interesses, importa entender o orçamento como mais do que a alocação de escassos recursos entre atividades $x$ e $y$ (WILDAVSKY, 1961). Nessa linha, orçamento é o encontro de necessidades conflitantes apresentadas pela sociedade e trazidas para a arena política, em ajustes incrementais nas decisões sobre alocações orçamentárias. Apesar das pesquisas e análises de Wildavsky terem como objetivo a definição de modelos que pudessem descrever as decisões, no processo orçamentário, tratado como incremental, abordava o orçamento como um campo com diversas variáveis atuantes sobre todo o processo, e por consequência, seus resultados.

A questão da representatividade de interesses que afloram na esfera política apresenta uma característica de instabilidade. As mudanças no mercado de trabalho, tornaram instáveis e fluidas as grandes categorias populacionais outrora passíveis de representação por sua posição na estrutura ocupacional. Assim, a representatividade política dos grupos não é contínua e permanente, podendo ocorrer alterações nos interesses pleiteados pelos agentes políticos (LAVALLE; HOUTZAGER; CASTELLO, 2006).

Essa percepção reforça a caracterização do orçamento público como um campo no qual estão em disputa diversos interesses, ocorrendo alterações nas representatividades em conflito, inclusive com a emergência de novos grupos e preferências. A necessidade 
de acomodação e os recursos limitados inviabilizam estabilidade absoluta dos acordos, nos orçamentos anuais ao longo dos anos, até mesmo pela variabilidade dos agentes envolvidos.

O orçamento público norte-americano transformou-se mais em uma mesa aberta de negociações do que em instrumento que define a política do Estado (LELOUP; 2002). O orçamento público é um meio em ebulição, com papel de maior relevância, devido às severas restrições impostas pelos limites fiscais, com demandas de contenção dos gastos públicos, situação recorrente no atual contexto mundial.

\subsubsection{Incrementalismo}

Dentre as mudanças de agendas observadas por LeLoup (2002), no processo orçamentário, parte-se do modelo inicial, classificado como incremental (DAVIS; DEMPSTER; WILDAVSKY, 1966), no qual as decisões atuais consideram a forma pretérita de realização das ações, acrescidas de pequenas variações, e, eventualmente, variáveis associadas a fatos extraordinários, descrita por meio da equação:

$$
\mathrm{X}_{1}=\mathrm{B}_{0} * \mathrm{Y}_{\mathrm{t}-1}+\mathrm{E}_{\mathrm{t}}
$$

em que: $X_{1}=$ valor a ser destinado na proposta orçamentária;

$\mathrm{B}_{0}=$ percentual ou média de incremento

$\mathrm{Y}_{\mathrm{t}-1}=$ valor alocado no exercício anterior

$\mathrm{E}_{\mathrm{t}}=$ variável que ocorre ocasionalmente, fora do incremento esperado.

A relação construída demonstra o fato de que a alocação de recursos - $\mathrm{X}_{1}$ sofre interferências adicionais em sua definição, normalmente devido a circunstâncias e situações extraordinárias, não regulares $-\mathrm{E}_{\mathrm{t}}$, além da base estável $-\mathrm{B}_{0} * \mathrm{Y}_{\mathrm{t}-1}$, que tem por referência as execuções verificadas em anos anteriores. As variações das alocações anuais de recursos fora da curva $\left(=\mathrm{B}_{0} * \mathrm{Y}_{\mathrm{t}-1)}\right.$ podem ser negativas ou positivas, representadas 
por $\mathrm{E}_{\mathrm{t}}$, significando riscos à previsibilidade orçamentária, decorrente grosso modo de fatores externos (DAVIS; DEMPSTER; WILDAVSKY, 1966).

O incrementalismo traz em si algumas características, tais como, um processo decisório bottom-up, considerado a partir da apresentação, pelas unidades executoras, de necessidades que serão avaliadas por instâncias superiores e decididas por critérios incrementalistas. O contexto de crescimento econômico com estabilidade confere linearidade ao processo decisório orçamentário, com atuação e presença governamentais crescentes, porém as decisões são tomadas e discutidas, internamente, como pouca interferência externa (LELOUP, 2002).

Cabe destacar que o conceito de incrementalismo tem sido abordado e tratado sob diversos entendimentos, tendo sido identificados doze significados distintos (BERRY, 1990). A "bonança" do termo coincide com a época em que Wildavsky construiu seu modelo. Face às crescentes restrições decisórias do processo orçamentário, houve maior pressão e participação de outros atores, anteriormente excluídos das deliberações, principalmente o Poder Legislativo, o qual ampliou seu papel, sujeitando certas decisões à sua avaliação e anuência, tornando o orçamento mais representativo. Nesse quadro, o orçamento se tornou uma mesa de negociações, não mais admitido como um processo interno do Executivo.

A mudança de cenário, a partir da década de 1970, com extensão até pelo menos os anos 1990, incluiu a ocorrência de sucessivos déficits públicos, com redução do crescimento econômico e até estagnação (LELOUP, 2002). Com esta alteração de cenário, a necessidade passou a ser de orçamentos equilibrados, com redução das despesas discricionárias, devido, também, ao crescimento dos gastos de natureza obrigatória.

Dessa forma, o modelo de decisão se alterou, com a preponderância de um modelo decisório do tipo top-down, estabelecido com vistas a garantir e evitar o crescimento 
acentuado do déficit público. As decisões dos valores a serem alocados, nas leis orçamentárias anuais, passaram a derivar de orientação superior, com vistas a assegurar a obtenção de um resultado global, considerando a definição de limites gerais para cada entidade apropriar em suas propostas orçamentárias.

Uma visão objetiva trata o orçamento como sendo constituído de dois mundos, um político, no qual o conflito é constante e as mudanças ocorrem frequentemente e conforme os atores e grupos envolvidos, e outro procedimental, em que prevalece a ordem, estável e incremental (SCHICK, 2000). Considerando os novos paradigmas, a partir do início do século XXI, tem sido apontado que, aparentemente, o período de grandes déficits já foi superado, porém não há possibilidade de retorno ao incrementalismo, até mesmo pelas diversas características atuais. Em sua visão, as decisões orçamentárias ainda seguem majoritariamente o modelo top-down, herança do que o autor chama de "deficit era", porém sem desconsiderar as propostas do bottom-up (LELOUP, 2002).

A abertura do processo decisório apresenta-se irreversível, com maior participação do Poder Legislativo e de diversos grupos de interesse, interferindo, diretamente, na alocação de recursos. Apesar da estabilidade, as negociações são intensas, porém a forma é mais aberta e clara, com vistas ao atendimento de diversas demandas colocadas pela sociedade.

O processo orçamentário brasileiro é orientado por instrumentos legais. Dentre eles, destaca-se a Lei de Responsabilidade Fiscal (Lei Complementar n⿳0 101, de 4 de maio de 2000), que, entre outros comandos, dispõe que o Anexo de Metas Fiscais, estabelecerá, anualmente, a meta de resultado primário a ser obedecida na elaboração e execução das leis orçamentárias anuais, integrará as leis de diretrizes orçamentárias. Esta orientação confere ao processo orçamentário uma característica top-down mais acentuada. Há 
previsão de um referencial, a meta de resultado primário, pela qual os recursos alocados, entre as entidades que integram os orçamentos, obedeceriam um teto no intuito de assegurar o seu cumprimento.

Assim, a variabilidade orçamentária anual é um fato do processo orçamentário, representado pela incerteza nos valores alocados às entidades e programações nos orçamentos anuais. Do incrementalismo, fica a noção de que os efeitos das mudanças seriam compartilhados conforme critérios do justo quinhão (PADGETT, 1986). Isso significa que, proporcionalmente, tais mudanças seguiriam padrões lineares entre as programações e os agentes, proposta como o modelo do julgamento serial como alternativa ao incrementalismo. $\mathrm{O}$ incrementalismo também reflete a teoria da natureza humana, ao atender interesses pessoais, ou seja, a satisfação dos agentes envolvidos no processo, em lugar da otimização alocativa geral (RUBIN, 1989).

\subsection{2_Equilíbrio pontuado}

Outro modelo que aborda a dinâmica do processo orçamentário é o do equilíbrio pontuado, que tem sua origem na teoria evolucionista, identificando períodos curtos de mudanças bruscas e acentuadas, que se intercalam com longos períodos de estabilidade. O equilíbrio pontuado é uma teoria familiar para os evolucionistas, para quem a evolução não é uma progressão constante de mudanças, mas caracterizada por longos períodos de estabilidade, interrompidos por mudanças bruscas e marcantes (REPETTO, 2007).

Os cientistas políticos aplicam os princípios do equilíbrio pontuado para explicar o processo de elaboração de políticas, e, particularmente, as políticas governamentais reconhecidas como incrementais, incluindo interrupções de forma não frequente, irregular e abrupta por meio de mudanças significativas. 
A aplicabilidade do modelo do equilíbrio pontuado ao processo político decorreu da insatisfação com a abordagem que enfatizava a estabilidade (JONES; BAUMGARTNER, 2012), mediante regras, ajustes incrementais e impasses, quando o que se nota é que as mudanças políticas ocorrem de forma não correlacionada, episódica e, às vezes, imprevisível.

As bases do equilíbrio pontuado refletem um processo abrupto de mudanças de políticas, sem correlações aparentes, cujas mudanças ocorrem, após intervalos longos caracterizados pela estabilidade (JONES; BAUMGARTNER, 2012). Destacam ainda os autores, que sua percepção da aplicabilidade do equilíbrio pontuado ao processo decisório político é chamadą por alguns de incrementalismo pontuado. Os micro fundamentos do equilíbrio pontuado são a racionalidade limitada e rejeição da percepção de que o ser humano toma suas decisões a partir de análises de custos e benefícios (JONES, 1999). Assim, além de os tomadores de decisões serem prisioneiros de seu conhecimento limitado, são influenciados pelo seu lado emotivo.

No equilíbrio pontuado, as mudanças orçamentárias sofrem pouca influência do processo eleitoral, sendo que mudanças de agenda podem ser verificadas, na ausência de influências decorrentes de eleições ou demandas oriundas de manifestações da opinião pública (JONES; BAUMGARTNER, 2012). No processo decisório, como o fluxo de informações enfrenta fricções, a ocorrência das mudanças decorre de situações nas quais as informações, externas ou internas, têm potencial individual ou acumulado suficiente para superar as inércias incrementais. Por isso, os períodos de estabilidade são longos, e, após a incidência de uma mudança, alcança-se o equilíbrio, que tende a ser mantido, até pela proteção das fricções, traduzíveis em custos transacionais incorridos para a obtenção de mudanças no status quo. 
O modelo do equilíbrio pontuado é considerado como uma boa explicação de boa parte das alterações verificadas na escolha de políticas, sua efetividade maior constata-se em subsistemas, sem o mesmo objetivo de modelo explicativo abrangente das escolhas políticas do incrementalismo (JONES; BAUMGARTNER, 2005). Dessa forma, vinculam o incrementalismo aos resultados obtidos, no processo regular de escolhas, e o equilíbrio pontuado, aos casos excepcionais dentro do incrementalismo. Essas observações, na análise dos autores, são consistentes com a trajetória observada do orçamento público dos Estados Unidos.

Analisando o impacto da reorganização do Congresso e o modelo do equilíbrio pontuado, observou-se pouca vantagem inferencial na sua aplicabilidade ao orçamento (ROBINSON; CAVER, 2006).

No entanto, tem sido reafirmada a aplicabilidade do modelo do equilíbrio pontuado à política, em observação histórica da série de curtos períodos de instabilidade seguida por extensos períodos de estabilidade, considerando-o eficaz na explicação desse fenômeno (ROBINSON; CAVER; MEIER; O’TOOLE JR., 2007).

Em abordagem comparativa (BAUMGARTNER; BREUNIG; GREENPEDERSEN, 2009), sobre a aplicabilidade do equilíbrio comparado, em três países distintos (Bélgica, Dinamarca e Estados Unidos), foi feita a análise do impacto do desenho institucional, nas mudanças de resultado nos processos governamentais, e verificado que a fricção institucional aumenta no decorrer do processo do ciclo político. Apesar das diferenças de regimes e instituições verificadas, nos países objeto do estudo, as distribuições de frequência apresentaram acentuado grau de curtose, ou seja, desvio em relação à distribuição normal. A distribuição normal significaria que mudanças de atenções e atividades governamentais seriam proporcionais entre si e menos sensíveis às 
mudanças das demandas sociais. A constatação, nos países avaliados, é que os altos custos transacionais em processos decisórios elevam os valores de curtose.

Os padrões de variações levantados sugerem que as curtoses elevadas, verificadas nas diferenças de distribuição entre as demandas (inputs) e os resultados (outputs), em um processo político, decorrem do comportamento da racionalidade limitada em ambiente social complexo (BAUMGARTNER; BREUNIG; GREEN-PEDERSEN, 2009). O conceito mencionado de fricções cognitivas e institucionais refere-se aos fatores que interferem, na proporcionalidade, entre insumos e produtos do processo político, representando custos transacionais.

A racionalidade limitada trata do comportamento em processos decisórios, considerando que as tomadas de decisões ocorrem sem um conhecimento de todas as variáveis envolvidas. Assim, a racionalidade limitada e a escolha comportamental levam à percepção de que os resultados do processo político são dissociados e representam episódios independentes das demandas políticas e do custo das estruturas das organizações envolvidas (JONES, 2003). Também afirma que as organizações integradas por racionalidade limitada não podem evitar resultados pontuais, porque seus integrantes não conseguem ajustar seus comportamentos às novas informações de qualquer nível de complexidade.

Na aplicação do equilíbrio pontuado ao processo orçamentário, as mudanças, a cada período, não eram normalmente distribuídas, como esperado pelo modelo incremental, mas de característica leptocúrtica, com pequenos picos, demonstrando que as mudanças no orçamento não poderiam ser explicadas por um modelo linear, como o incrementalismo (JONES; BAUMGARTNER, 2012). Comparando percepções e aplicações do equilíbrio pontuado, em países da Europa, perceberam que os padrões se 
repetem, sendo identificadas resistências ou fricções cognitivas e institucionais presentes em outros sistemas políticos.

Nessa linha, os padrões orçamentários decorrem das resultantes das diferentes fricções verificadas nos diversos contextos mediados pelas características institucionais. O nível de resistência ou fricção institucional tende a ser baixo, no início do processo, e crescente no seu transcorrer, atingindo níveis mais elevados próximos ao seu final. Isso permite inferir que a opinião pública parece ser mais importante no início do ciclo e menos importante ao final do ciclo. No caso brasileiro, uma maior incidência de alterações no início do processo, ou maior variabilidade orçamentária, poderia confirmar esse pressuposto.

Assim, as alterações mais significativas no processo orçamentário tenderiam a ocorrer durante a apreciação da proposta orçamentária pelo Poder Legislativo. As mudanças orçamentárias pontuais parecem estar relacionadas a período de baixo crescimento econômico, durante longo tempo, ou seja, estabilidade com baixo crescimento catalisariam mudanças pontuais e episódicas (JONES; BAUMGARTNER, 2012).

Em estudo sobre os orçamentos dos estados americanos, para tentar identificar as causas das mudanças pontuais, assim entendidas aquelas mais radicais, que ocorrem esporadicamente, como relatadas no modelo do equilíbrio pontuado, pode ser constatado que o conjunto das demandas e o poder de veto governamentais aumentam a extensão na qual os orçamentos apresentam mudanças pontuais (BREUNIG; KOSKI, 2009). Perceberam, também, que governos fortes podem dominar as agendas orçamentárias, mas estão sujeitos a aumentos nos custos de informação. Dessa forma, governos fortes podem impedir alternativas legislativas, nas discussões orçamentárias, porém o bloqueio a tais 
alternativas pode resultar na indução de custos transacionais capazes de obstruir ajustes na política fiscal.

Examinando os orçamentos públicos (JONES; BAUMGARTNER; BREUNIG, 2009), no intuito de tentar definir uma lei geral empírica que lhes fosse aplicada, estudo concluiu que os orçamentos públicos são marcantemente incrementais, a maior parte do tempo, porém ocasionalmente são verificadas grandes e significativas mudanças. Essa percepção fundamenta-se no entendimento de que o orçamento é a representação quantitativa de decisões políticas coletivas tomadas em resposta a previsão de arrecadação, preferências dos tomadores de decisões e estruturas institucionais que definem incentivos para as decisões.

Desse modo, a distribuição dos resultados do orçamento é essencial para o estudo das mudanças políticas. Nesse sentido, a expectativa é de que o orçamento reflita as mudanças das prioridades governamentais e os respectivos custos transacionais. A análise dos modelos e padrões orçamentários ajuda a compreender o comportamento das variáveis orçamentárias, objeto do presente estudo, com vistas a possibilitar uma tentativa de prever determinado comportamento e seu impacto na governança do setor público.

\subsection{Etapas do processo orçamentário}

O processo orçamentário envolve etapas que se desenrolam antes e após a aprovação da lei orçamentária anual (GIACOMONI, 2010). Tal processo é um emaranhado complexo e sucessivo de momentos, no qual diversos atores atuam para assegurar o atendimento a seus interesses e dos grupos que representam. Sua existência ocorre apenas em estado dinâmico, em funcionamento, sendo também chamado de ciclo 
orçamentário, exercendo considerável influência no desempenho do Estado (SUZART, 2011).

Podem ser identificadas quatro etapas no processo orçamentário (GIACOMONI, 2010), quais sejam: a) elaboração da proposta orçamentária - PLOA; b) discussão, votação e aprovação da lei orçamentária anual - LOA; c) execução orçamentária; e d) controle de avaliação da execução orçamentária. Esse processo é dinâmico, em estado de constante movimentação e sujeito a ajustes em seu desenvolvimento. A Figura 1 representa o processo orçamentário no âmbito do Governo Federal, conforme designação de Giacomoni.

Figura 1 - Processo orçamentário

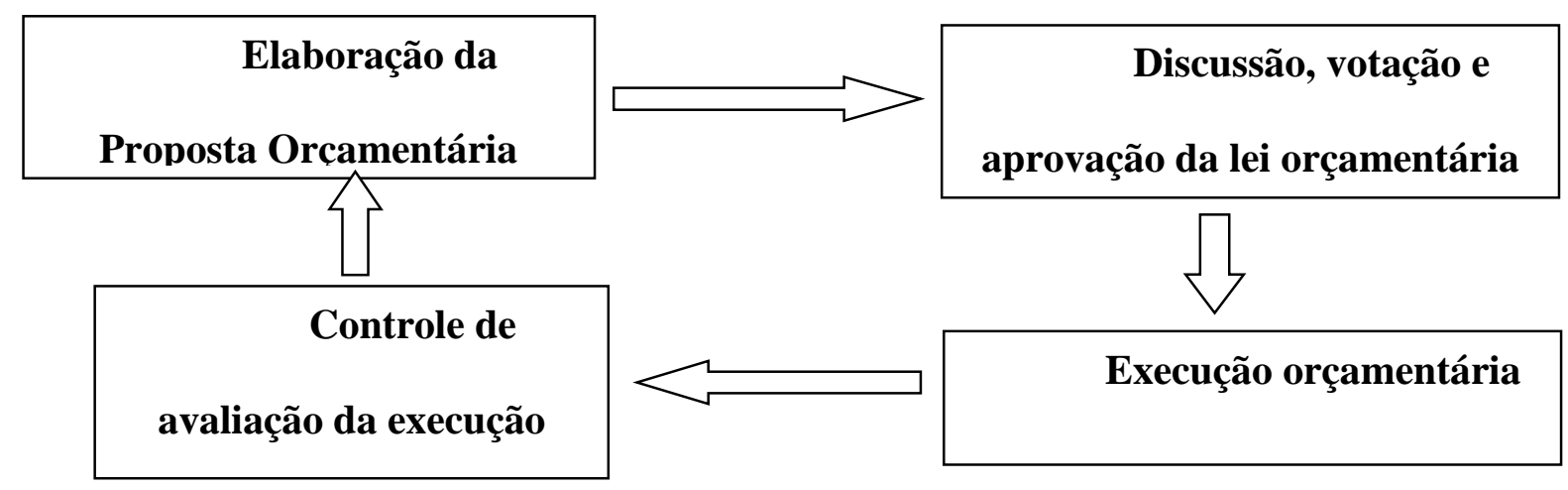

Fonte: Giacomoni (2010) 


\subsubsection{PLOA - Projeto de Lei Orçamentária Anual}

A etapa de elaboração e apresentação do PLOA é competência privativa do chefe do Poder Executivo, prevista no art. 167 da Constituição Federal. Esse processo é coordenado pela Secretaria de Orçamento Federal do Ministério do Planejamento, Orçamento e Gestão - SOF/MP (GIACOMONI, 2010). As diretrizes que orientam a elaboração das LOAs constam das leis de diretrizes orçamentárias - LDOs, aprovadas prévia e anualmente ao encaminhamento do PLOA ao Congresso Nacional (PEREIRA; MUELLER, 2002). A elaboração da PLOA segue uma orientação de cima para baixo, na qual como referência inicial é estabelecida uma meta de resultado fiscal, tendo como objetivo de assegurar a obtenção de um resultado primário superavitário.

Esse parâmetro é fixado nas LDOs, aprovadas por lei ordinária, que impõe compulsoriedade em seu cumprimento. A partir das estimativas de receitas públicas e do cálculo das necessidades de financiamento do governo central - NFGC e da identificação do montante da dívida a ser refinanciada, são definidos os recursos disponíveis para o atendimento das despesas públicas, assegurada a "reserva" para cumprimento da meta fiscal.

Dos recursos disponíveis para os gastos públicos, é realizada inicialmente a projeção dos gastos obrigatórios, tais como o pagamento de despesas com pessoal ativo e inativo e demais obrigações legais. O restante é destinado para os gastos discricionários, os quais tratam do custeio administrativo e dos investimentos, para os quais há liberdade na definição dos referenciais monetários.

A Figura 2 descreve o fluxo do processo de elaboração do PLOA. 


\section{Figura 2 - Processo de elaboração do PLOA}

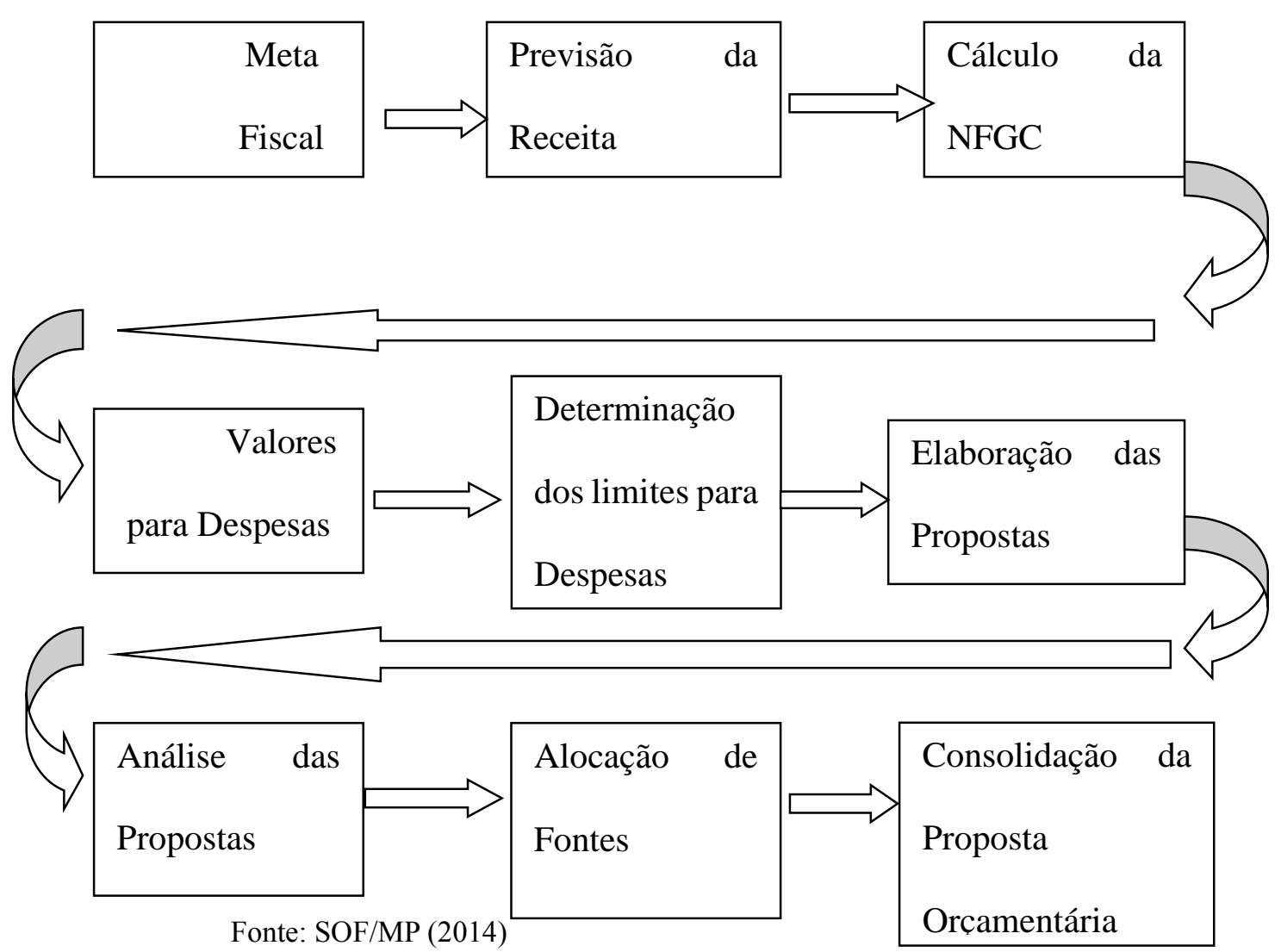

A distribuição dos referenciais monetários entre as despesas discricionárias dos órgãos da Administração Pública Federal, durante a elaboração das propostas setoriais, segue critérios técnicos e orientação política. Nesse momento, pode ser entendido que está colocada a possibilidade de diversos atores e grupos de interesse tentarem interferir na distribuição dos recursos entre as programações dos órgãos setoriais conforme seus interesses.

Um ponto importante a ser observado nessa primeira etapa do processo orçamentário é a pouca transparência dos critérios decisórios, no que diz respeito às decisões alocativas destinadas ao atendimento das despesas discricionárias. O ambiente das decisões é interno ao Poder Executivo, apesar da participação de grupos partidários interessados, refletidos pela posição de integrantes dos partidos da coalizão governante 
nos órgãos e cargos que compõem a administração pública. Como observa Suzart (2011), a ausência de transparência dos critérios pode acarretar confusão nos eleitores, enquanto um aumento dessa transparência propiciaria a estabilidade econômica e crescimento de alta qualidade.

Essa etapa termina com a submissão do PLOA ao Congresso Nacional, e, para fins da presente pesquisa, irá detalhar os valores totais atribuídos a cada unidade orçamentária da União. Com base nos critérios das pesquisas orçamentárias já referidas, serão considerados quatro formas de apuração: os gastos totais, custeio e investimento, apenas investimentos e emendas parlamentares individuais.

\subsubsection{LOA - Lei Orçamentária Anual}

A segunda etapa abrange a discussão, votação e aprovação da LOA, e está sob a responsabilidade do Poder Legislativo, cujo processo está previsto no art. 166 da Constituição Federal. Nesse ambiente de representatividade, integrado pelas mais diversas tendências e variados grupos de interesses, a disputa é intensa. Cada parlamentar busca o atendimento dos interesses que representa.

A partir da proposta encaminhada pelo Poder Executivo - PLOA, o Poder Legislativo poderá realizar as alterações que julgar pertinentes, respeitados os critérios estabelecidos na Constituição Federal para que as alterações sejam realizadas, a exemplo da obrigatoriedade da indicação da fonte compensatória e da vedação do cancelamento de dotações previstas para despesas de caráter obrigatório, como gastos com pessoal e serviços da dívida.

No entanto, no processo orçamentário federal, ao enviar o PLOA, conforme previsão nas LDOs, são reservados recursos para alterações parlamentares. Assim, cada parlamentar já tem garantido seu direito de incluir recursos, para finalidades do seu 
interesse, até determinado montante global, definido por meio de regimento interno. Esse fato assegura que, no decorrer da discussão, votação e aprovação da LOA, no Poder Legislativo, diversas alterações serão incorporadas, a partir de interesses representados pelos parlamentares.

As alterações introduzidas, pelo Poder Legislativo, ao PLOA ocorrem por emendas parlamentares, que são classificadas dos seguintes tipos: de relator, de comissão, de bancadas estaduais e regionais, e individuais, de acordo com o regimento interno da CMO. A participação, nas alterações no PLOA, pode ter sua origem em cargos políticos, como o relator, cuja definição depende de acordos políticos entre os líderes dos partidos majoritários ou de bancadas mais expressivas. Existem outros fundamentos para os acordos, como interesses comuns das comissões temáticas ou bancadas regionais, congregando parlamentares com origem em determinada região, ou das emendas individuais, baseadas em percepções pessoais.

As alterações ao longo da discussão, da votação e da aprovação da LOA decorrem de acordos e de um concurso de vontades e interesses ou ainda de vontade personalista. Sobre a importância dos atores políticos no processo orçamentário e a liberação para execução de emendas parlamentares, foi feito um levantamento e apontada a predominância da execução de emendas parlamentares incluídas nas leis orçamentárias por membros dos partidos de coalizão, principalmente, os de maior representatividade (PEREIRA; MUELLER, 2002).

O processo orçamentário, no Poder Legislativo, ocorre mediante apreciação conjunta da Câmara dos Deputados e do Senado Federal. A Comissão Mista Permanente de Orçamento - CMO é a instância na qual ocorrem as discussões e são apresentadas as propostas de alterações, ou emendas parlamentares. O fluxo do processo orçamentário, no âmbito do Poder Legislativo, observa regras constitucionais e regimentais, que 
disciplinam prazos e condições de encaminhamento e aprovação das emendas parlamentares, compatibilizados com a previsão de dispositivos constitucionais, impondo restrições às alterações no PLOA.

A Figura 3 representa o processo orçamentário legislativo:

\section{Figura 3 - Processo Orçamentário Legislativo}

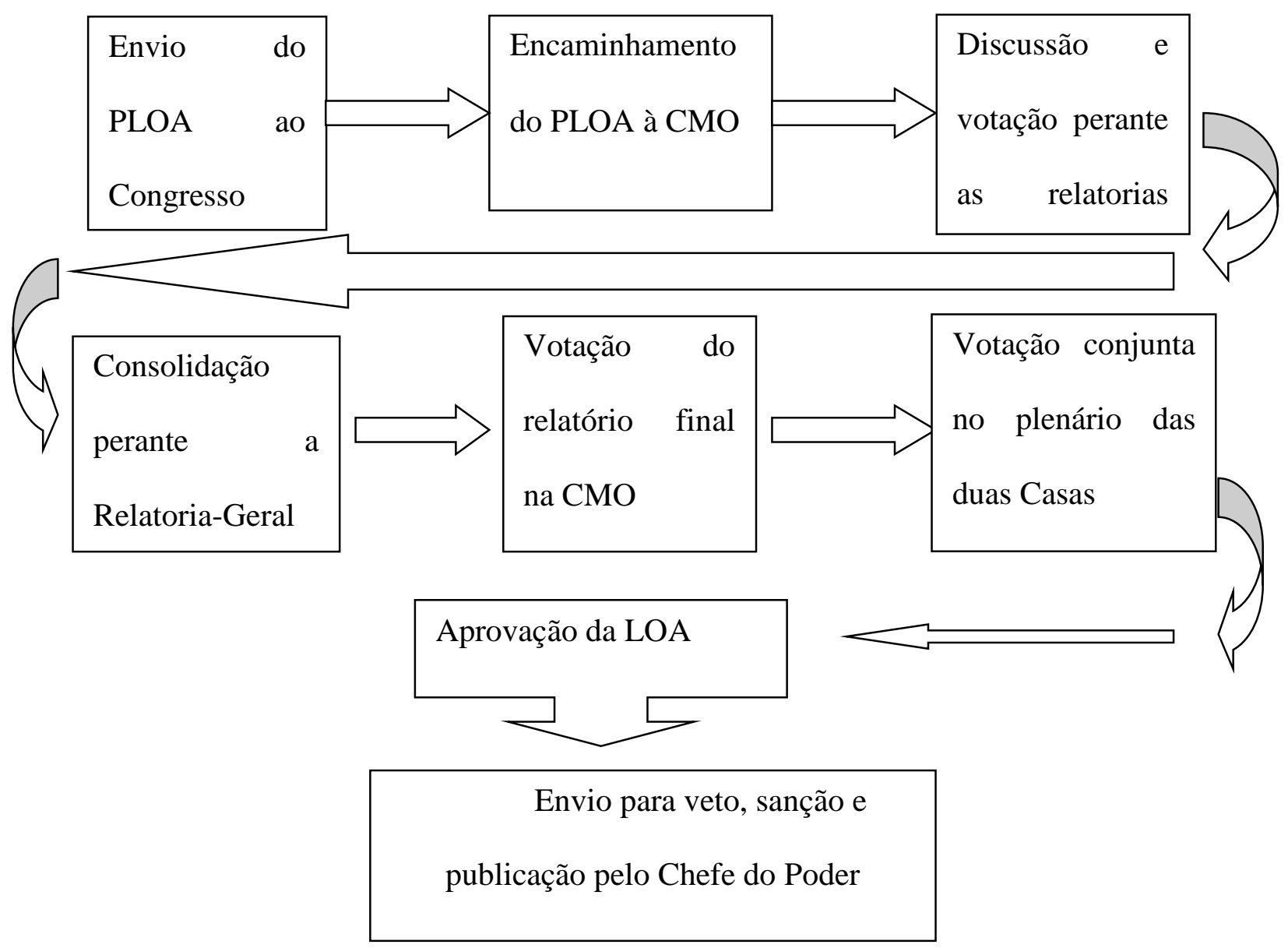

Fonte: SOF/MP (2014)

Estudo destaca que o presidencialismo brasileiro utiliza a liberação das emendas parlamentares individuais para punir ou recompensar aqueles que votam, favoravelmente ou desfavoravelmente, aos seus interesses (PEREIRA; MUELLER, 2002). Acrescentase, ainda, que as emendas parlamentares individuais representam, para seus autores, um fator importante em suas reeleições e carreiras políticas, daí a sua utilização como moeda de troca na barganha política. 
Em avaliação sobre o impacto das emendas individuais (FIGUEIREDO; LIMONGI, 2008), foi observado que, ainda que sejam de menor valor, em comparação com as emendas de relator, comissões e de bancadas; ainda assim, são cruciais para a operação da base parlamentar do Governo. O impacto global sobre o PLOA do acréscimo que as emendas parlamentares ocasionam, caso não seja identificado erro na projeção das receitas públicas representa em torno de $1 \%$ (um por cento) da receita corrente líquida RCL, de acordo com previsão nas últimas LDOs. Essa receita pública é oriunda, majoritariamente, da arrecadação de tributos deduzida das transferências compulsórias a serem realizadas para outros entes da Federação.

Em um exame sobre a gestão da execução das emendas parlamentares, para manutenção da governabilidade, no sistema de presidencialismo de coalizão brasileiro, foi concluido que o valor destinado ao seu atendimento é extremamente baixo, em comparação com os montantes totais aprovados nas LOAs (PEREIRA; MUELLER, 2002), haja vista que, majoritariamente, os recursos orçamentários visam a atender gastos obrigatórios, tais com o pagamento e refinanciamento da dívida pública, transferências constitucionais aos entes da Federação e seguridade social, além dos gastos operacionais, reduzindo, drasticamente, a possibilidade de alterações mais substanciais na LOA.

As alterações parlamentares abordam, basicamente, gastos com investimentos do setor público, cujas emendas parlamentares coletivas e individuais representam entre $18 \%$ e $25 \%$ do total de recursos alocados a investimentos (PEREIRA; MUELLER, 2002). As alocações por emendas parlamentares são condicionadas a forma e conteúdo determinados pelas decisões e resoluções da $\mathrm{CMO}$, e a aprovação das emendas depende do seu acatamento pelo relator do PLOA (FIGUEIREDO; LIMONGI, 2008).

Após a aprovação do PLOA, compete ao Presidente da República analisar a forma e o conteúdo aprovados, e, se considerar ilegal ou contrário ao interesse público, propor 
vetos, que deverão ser analisados pelo Congresso. Ao analisar o processo orçamentário americano, foi observado que, quanto mais transparente o processo de elaboração, pelo Poder Executivo, menor a ocorrência de vetos, após a aprovação pelo Congresso, e que os aumentos no orçamento foram reflexos das mudanças institucionais (DEARDEN; HUSTED, 1990).

Essa etapa, caracterizada pela participação do Congresso Nacional, encerra-se com a aprovação e sanção da Lei Orçamentária, e a variação em relação ao PLOA é tratada como variável Congresso $(\mathrm{CON})$.

\subsubsection{Autorizado e Executado}

A execução das despesas orçamentárias refere-se à efetiva aplicação dos recursos previstos na LOA, que percorre alguns estágios até sua realização. É importante o fato de a LOA ser considerada uma lei autorizativa. Dessa forma, à exceção das despesas obrigatórias, cuja execução é compulsória, a realização das demais despesas, ditas discricionárias, dependerá da "boa vontade" do gestor do orçamento, no caso os dirigentes políticos responsáveis por cada área, como os ministérios setoriais. Essa discricionariedade, na execução da LOA, alcança inclusive as alterações introduzidas pelo Poder Legislativo, reforçando sua instrumentalização como meio de barganha política.

Todos os gestores dos órgãos setoriais estão sujeitos às orientações do chefe do Poder Executivo, o Presidente da República, que estabelece limitações de empenho, caso o comportamento da receita poderá comprometer o alcance da meta de resultado fiscal prevista nas LDOs, conforme previsto da Lei de Responsabilidade Fiscal - LRF. Essas limitações à execução das despesas aprovadas nas LOAs são conhecidas como contingenciamento. 
Os contingenciamentos são estabelecidos a partir dos decretos de programação orçamentária e financeira, decorrentes das avaliações bimestrais, previstas na LRF. Assim, a execução de uma despesa, particularmente as de caráter discricionário, como os investimentos, depende de acordos, durante os momentos que precedem o início de sua execução, que são: previsibilidade orçamentária (LOA), limites de movimentação e empenho previstos nos decretos de programação orçamentária e financeira, e disposição do gestor em iniciar os procedimentos para a realização da despesa.

O caminho para viabilizar a realização de uma despesa percorre diversos estágios, os quais podem configurar a realização de acordos variados, cujas manutenções e cumprimentos apresentam determinadas condições discricionárias, haja vista a possibilidade de alguns desses acordos não se concretizarem, no sentido de não alcançarem os seus cumprimentos, materializados pelas execuções das despesas previstas. A despesa pública, obrigatoriamente, deve cumprir os três estágios da Figura 2: empenho, liquidação e pagamento.

Figura 4 - Processo de execução discricionária da despesa pública

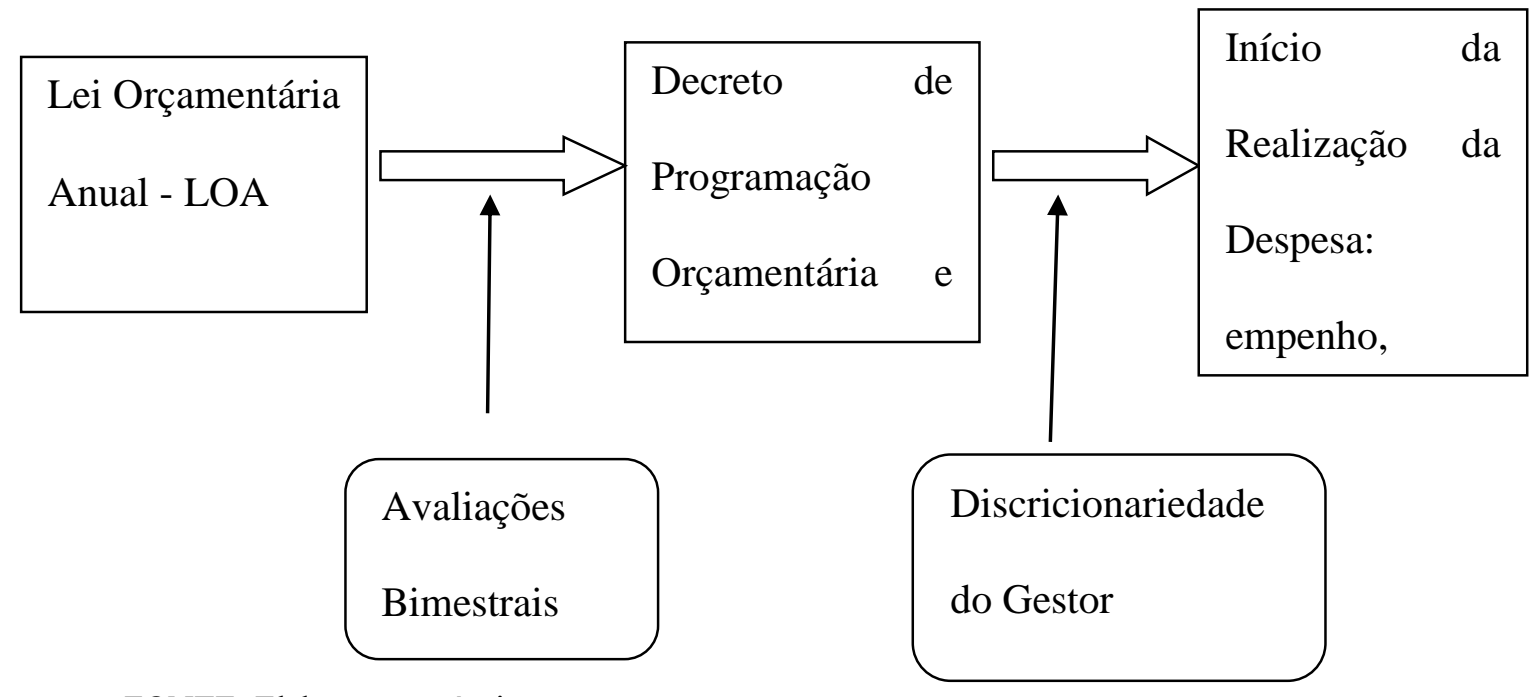

FONTE: Elaboração própria 
A falta de sincronia, entre a arrecadação fiscal e as despesas previstas, permite ao Poder Executivo agir estrategicamente, por meio do contingenciamento, na liberação de emendas, sob a justificativa da limitação de recursos, sendo as emendas parlamentares incluídas, normalmente, nos grupos passíveis de contingenciamento (PEREIRA; MUELLER, 2002). O controle de avaliação da execução orçamentária está previsto, no ciclo orçamentário, como o momento final de avaliação dos resultados alcançados, cuja percepção serve como subsidio para a elaboração da proposta orçamentária seguinte. A avaliação da execução orçamentária de tarefa busca constatar se os resultados almejados foram atingidos.

Em estudo sobre o processo decisório orçamentário em uma cidade dos Estados Unidos (FRANKLIN; RADSCHELDERS, 2004), foi observado que não são consideradas na literatura as diferenças que existem entre os valores individuais dos atores envolvidos e suas atuações quando estão sendo resolvidos os dilemas do processo decisório orçamentário. Esse estudo demonstra que os acordos previstos nos orçamentos buscam aproximar os desejos individuais dos atores, porém não constituem um reflexo idêntico às suas pretensões.

Outra situação verificada, a partir de levantamentos com servidores da área orçamentária dos Poderes Executivo e Legislativo, indica que a preponderância do Executivo no processo orçamentário pode estar terminando (GOODMAN, 2007). Isso ocorre devido, entre outros, à habilidade do Legislativo de acessar de forma independente as informações orçamentárias, à definição de agenda, separadamente do Executivo, à linguagem mais detalhada na alocação de recursos, e ao maior consenso nas estimativas das receitas públicas.

A compreensão do processo orçamentário e da sua dinâmica importa, para verificação dos momentos nos quais os acordos poderão ser alterados, mantidos ou 
sofrerem diversas interferências. O entendimento da oportunidade desses momentos é necessário para a tentativa de correlacionar as variáveis orçamentárias, permitindo inferências sobre os custos transacionais e, por conseguinte, aos reflexos na governança do setor público.

Após a aprovação da LOA podem ocorrer alterações de acordo com as conveniências e oportunidades. Assim, o valor final das autorizações orçamentárias para determinado exercício pode ser diferente do inicialmente aprovado, a partir da incorporação dos créditos adicionais, conceituadas como autorizações de despesas não computadas na LOA. Esse valor final da dotação é chamado de autorizado, que será objeto de avaliação em relação à etapa anterior. As alterações na LOA inicialmente aprovada são prerrogativas do Poder Executivo, que deverá encaminhá-las para aprovação pelo Poder Legislativo, podendo ocorrer algumas alterações já pré-autorizadas, ou seja, não dependem de nova autorização legislativa.

Essa fase está sob a gestão do Poder Executivo, e especificamente o MP, com a coordenação da SOF, é responsável pelo processo, exercendo forte domínio sobre as alterações que deverão ser encaminhadas. Posteriormente à previsão de dotação orçamentária, para que possam ser realizadas as despesas previstas na LOA, é necessário o empenho, pois nesse momento as dotações ficam comprometidas para finalidade ou gasto específico, após cumpridas todos os requisitos legais.

Os valores executados em cada exercício, além da previsão orçamentária, irão depender das autorizações para movimentação e empenho, previstas nos decretos de programação orçamentária e financeira. Eventualmente podem ocorrer limitações, os chamados contingenciamentos, impostos a partir das avaliações bimestrais, previstas no art. $9^{\circ}$ da Lei de Responsabilidade Fiscal, que porventura apontem indicação de frustração de receita em relação ao previsto na aprovação da LOA. Dessa forma, os valores 
executados podem oscilar em decorrência, entre outros fatores, das limitações de movimentação e empenho. Esse fato, objeto do presente estudo, significa que podem ocorrer variabilidades entre o valor autorizado e o efetivamente executado.

\subsubsection{Pago e Restos a Pagar}

O pagamento é o último estágio de realização da despesa pública. A responsabilidade pela sua definição é do Ministério da Fazenda, com a coordenação da Secretaria do Tesouro Nacional - STN/MF, conforme previsto na lei. Os limites financeiros oscilam conforme as disponibilidades de caixa. A despesa que tenha sua realização se iniciado em um exercício, porém não tenha sido concluída até o final, poderá ser inscrita em restos a pagar, faculdade conferida pela Lei 4.320, de 1964.

Os limites financeiros estabelecidos se destinam tanto a atender às despesas do exercício como as decorrentes de restos a pagar, competindo pelas disponibilidades financeiras. Um limite financeiro mais elástico permitirá, em tese, que os valores pagos superem os liquidados ou executados. As variabilidades entre o executado e o pago podem significar a postergação no cumprimento de obrigações já atestadas. Esse momento pode ser considerado como a fase final do cumprimento dos acordos refletidos no orçamento.

Para verificar qual a variação entre o pagamento após o início da realização das despesas, serão observadas razões, entre pago e executado e restos a pagar pagos e pagamentos de despesas do exercício.

\subsection{Ciclo político do processo orçamentário - Political Budget Cycle}


Political Budget Cycle - PBC é definido como flutuações periódicas, na política fiscal governamental, decorrentes do ciclo eleitoral (SHI; SVENSSON, 2003). Essa abordagem tenta identificar crescimento nos gastos públicos em anos pré-eleitorais, principalmente, aqueles referentes a transferências, posto que parte das variabilidades orçamentárias anuais sofreria influência dos ciclos eleitorais.

Estudando os PBCs, em estados da Alemanha Ocidental (SCHNEIDER, 2010), foi apontada a relação entre a observância de PBC e a transparência fiscal das instituições públicas, considerando que sua ocorrência é menos provável em contexto nos quais a transparência fiscal é elevada. Acrescentou, ainda, que, mesmo em situações nas quais são verificadas restrições ao crescimento de gastos em períodos pré-eleitorais, pode ocorrer a existência de $\mathrm{PBC}$, pois os responsáveis pelo gasto público buscam alternativas às "travas" eleitorais.

Na literatura, um dos achados mais robustos sobre PBC é a verificação do aumento das transferências sociais em períodos pré-eleitorais (SCHNEIDER, 2010). Essa indicação é colocada como tendência, em contextos de transparência fiscal e restrições institucionais ao crescimento dos gastos. Uma das formas mencionadas é a redução, na arrecadação de determinadas receitas, transferindo renda à população.

O PBC foi analisado (MINK; DE HAAN, 2006) nos países da Zona do Euro que já haviam adotado o euro, considerados industrializados, e sob o Pacto Regional de estabilidade que impõe o controle fiscal como compromisso entre seus integrantes, e foi encontrada fraca evidência da ocorrência de PBC na Zona do Euro; porém, quando verificados, os aumentos dos déficits orçamentários incidiram em anos eleitorais, ou seja, no ano da eleição e não no ano anterior.

Analisando países em situações distintas (STREB; LEMA; TORRENS, 2009), os casos mais incisivos de ocorrência de PBC, normalmente, foram encontrados em países 
em desenvolvimento e novas democracias. Essa afirmação toma como referência a Rússia, considerando, também, países nos quais há preponderância do Poder Executivo na determinação e execução da política fiscal. Assim, destacam os PBCs como decorrentes do excesso de discricionariedade na condução da política fiscal.

A análise do PBC nas democracias latino-americanas, incluindo estudos entre 1948 e 1970, permitiu identificar que os gastos públicos apresentaram crescimento, no ano anterior à eleição, e redução no ano posterior à realização das eleições (BARBERIA; AVELINO, 2011). Analisando o período de 1973 a 2008, foi confirmada a existência de PBC nas democracias latino-americanas, verificando a dependência depende da transição democrática dos países para sua caracterização. Ressalta-se que o PBC pode ser melhor entendida pela redução da arrecadação do que pelo aumento dos gastos. 


\section{METODOLOGIA}

O presente trabalho é uma pesquisa quantitativa, descritiva e de caráter exploratório. A fonte dos dados é secundária, a partir de informações orçamentárias coletadas de sistema oficiais, no caso o Sistema Integrado de Planejamento e Orçamento - SIOP, e o Siga Brasil, do Senado Federal. Ambos extraem dados para sua base de consulta do SIAFI - Sistema Integrado de Administração Financeira da Administração Pública Federal.

Nesse capítulo serão descritas as variáveis utilizadas e o método para identificação e análise das informações, que no caso é a análise de cluster. A aplicação da análise de cluster utilizará o programa Stata 12.

\subsection{Descrição das variáveis}

\subsubsection{Unidade Orçamentária (UO)}

Esse é o menor nível da classificação denominada institucional das leis orçamentárias anuais (MTO, 2015). Todas as programações orçamentárias estão descritas, em uma unidade orçamentária específica, que está vinculada a um órgão superior, a exemplo, dos ministérios no âmbito do Poder Executivo. Para que uma entidade possa ser "convertida" em unidade orçamentária, não há necessidade de ato legal, apenas o cadastro como unidade autônoma. Não há necessidade de a unidade orçamentária possuir personalidade jurídica, porém é possível distinguir unidades orçamentárias que integram a Administração direta e a indireta. 
As UOs estão representadas por um código de 5 (cinco) dígitos, dos quais os dois primeiros representam o órgão superior ao qual se vinculam, e os três restantes a unidade orçamentária propriamente dita, podendo indicar inclusive a sua natureza (MTO, 2015). A título de exemplo, quando os três últimos dígitos se iniciam por 1, significa que tal unidade orçamentária integra a Administração direta do órgão superior. Normalmente, quando iniciados por 9 significa tratar-se de fundos contábeis, se 2 entidades da Administração indireta, tais como empresas e autarquias, critério que vem sendo utilizado pela SOF/MP. Finalmente os órgãos que se iniciam por 7 são os chamados órgãos virtuais destinados a tratar de despesas referentes a transferências obrigatórias e despesas financeiras, designados também como operações oficiais de crédito. Dentre os códigos atribuídos às unidades orçamentárias, alguns critérios são importantes para esclarecimentos.

\section{Tabela 1 - Descrição dos códigos das unidades orçamentárias}

\begin{tabular}{l|l}
\hline Códigos & Unidades Orçamentárias \\
\hline iniciados com 0 até 1 & unidades dos Poderes Legislativo e Judiciário \\
\hline iniciados com 2 até 6 & unidades do Poder Executivo \\
\hline iniciados com 7 & $\begin{array}{l}\text { chamados órgãos virtuais, não possuem existência física, } \\
\text { estabelecidos para discriminar transferências obrigatórias a outros } \\
\text { entes federativos, despesas financeiras decorrentes da concessão de } \\
\text { financiamentos }\end{array}$ \\
\hline
\end{tabular}

Fonte: Elaboração própria a partir do MTO-2015

As mencionadas unidades classificadas como do Poder Executivo (códigos iniciando com 2 a 6) incluem o Ministério Público da União, que, apesar de não integrálo, utiliza-se dos códigos que lhe estão atribuídos. Ademais, consta do Orçamento Geral da União - OGU, para efeito de resultado, a contabilização da unidade orçamentária 90000 - Reserva de Contingência, integrada pelos recursos não apropriados nas 
programações de despesa, e contabilizados como decorrente do resultado superavitário previsto nas diretrizes das Leis de Diretrizes Orçamentárias - LDOs.

As transformações, inclusões, exclusões e cisões ocorrem em todos os exercícios, representando uma tendência crescente, seja pela necessidade ou desejo de maior autonomia dos entes públicos, seja pelos ajustes decorrentes da busca por uma maior transparência das atribuições exercidas, principalmente em face de políticas públicas prioritárias.

Ponto esclarecedor é o fato de os códigos nunca terem sido reutilizados até o presente momento, ou seja, unidades que trocaram de códigos, pelos diversos motivos já mencionados, terão o código anterior inutilizado, não podendo servir a novas unidades orçamentárias. Tal fato é positivo, tendo em consideração a impossibilidade de duas unidades orçamentárias distintas utilizarem o mesmo código, mesmo que em momentos temporais diversos.

As unidades orçamentárias consideradas nesse estudo integraram os Orçamentos Fiscal e da Seguridade Social da União, ou seja, a pesquisa não abordou as unidades do Orçamentos de Investimento das Estatais, constituído pelas empresas estatais independentes, isto é, que não dependem de recursos do Tesouro para subsistirem.

Tendo em vista a flexibilidade na criação da unidade orçamentária, verificam-se oscilações, ao longo dos exercícios, por criações e exclusões, algumas decorrentes de cisões, meras transformações ou até decorrentes de mudanças de alteração na vinculação institucional. Dessa forma, esses ajustes não implicam necessariamente em expansão da atividade governamental, mas em mera mudança de classificação e categorização.

Essa fragmentação também atende a lógica alocativa, na medida em que permite melhor acomodação dos interesses da coalizão no poder. Tal fragmentação quebra a série 
histórica de determinada unidade orçamentária, principalmente quando decorrente da mudança da classificação institucional.

\subsubsection{Ano}

O período analisado, pelo presente trabalho, abrange os exercícios de 2002 a 2012. O corte temporal, a partir de 2002, decorre da disponibilidade de dados mais confiáveis, pois, em período anterior, até mesmo devido à alteração da classificação orçamentária, de funcional-programática para a classificação funcional, diversas séries de dados foram desconsideradas ou não ajustadas, como no sistema utilizado nesta pesquisa, o Sistema Integrado de Orçamento e Planejamento - SIOP. Como no início do levantamento, o ano de 2013 ainda não havia sido encerrado, optou-se pelo limite em 2012. Como previsto na legislação, a anualidade orçamentária é coincidente com o ano civil.

\subsubsection{Tipos}

Os tipos foram considerados, conforme grupos de natureza das despesas, a partir da classificação detalhada da categoria econômica. Assim, a avaliação foi aplicada, considerando parcelas ou subgrupos, dentro de grupos mais amplos, tomando por

referência os grupos de despesas: 3 (outras despesas correntes), 4 (investimentos) e 5 (inversões financeiras), e o geral, incluindo também os demais grupos de despesas como 1 (pessoal), 2 (juros e outros encargos da dívida), 6 (amortização da dívida).

A ênfase, nos grupos 3, 4 e 5-OCK (Outras despesas correntes e capital), e apenas 4, além do total, conforme a classificação por categoria econômica, busca verificar a volatilidade dessas despesas, tendo em vista constituírem gastos em grande medida discricionários, principalmente no caso dos investimentos, dependendo de acordos entre 
os atores envolvidos nas várias etapas do processo orçamentário para a consecução dessas despesas.

A análise dos gastos do grupo 4, referente a investimentos, deve considerar que representam as despesas que estão voltadas, precipuamente, para obras, gerando uma contrapartida de acréscimo patrimonial. Esses gastos, normalmente, são aqueles que mais sofrem restrições quando é verificada a necessidade da realização do contingenciamento, que é a limitação de empenho com vistas a assegurar o alcance das metas físcais, conforme verificado em exercícios anteriores. Contudo, gastos com investimentos possuem maior visibilidade externa para a população, pois representam as grandes realizações palpáveis, o que atrai a atenção de diversos atores políticos, com vistas a maior penetração no eleitorado de forma geral (PEREIRA; MUELLER, 2002).

A abordagem sobre investimentos não considerou as diferentes categorias de prioridades, como atualmente tem-se estabelecido o Programa de Aceleração do Crescimento - PAC, o qual confere a determinados investimentos, constantes do seu rol, menores restrições em suas execuções.

A base Outras Despesas Correntes e de Capital - OCK permitirá verificar se as variabilidades concentram-se em grupos específicos, ou podem ser consideradas como aplicáveis a grupos mais amplos, pois boa parte das despesas referente ao grupo 3 tratam de gastos com a manutenção administrativa e serviços regulares, os quais, apesar de sua discricionariedade, impõem a recorrência com vistas à manutenção dos serviços regulares. Tal fato de forma semelhante poderá ser verificado, quando abordado o conjunto de todas as despesas do setor público, incluindo os gastos com pessoal e pagamento de serviços da dívida. Vale lembrar que as despesas com pessoal e serviços da dívida são de caraterística compulsória, sendo, dessa forma, sua execução obrigatória, após a verificação do fato gerador, conforme definido na LRF. 
As emendas individuais constituem um grupo para avaliação da variabilidade orçamentária. Esses valores são decorrentes das alterações que, individualmente, cada parlamentar, seja deputado ou senador, tem direito a propor durante a apreciação do PLOA. As regras e os montantes aos quais cada parlamentar faz juz são disciplinados, por meio de regulamento interno, e são de livre alocação conforme o desejo de cada parlamentar. Figueiredo e Limongi (2005) consideram que a execução das emendas parlamentares individuais são utilizados como moeda de troca para concretizar acordos entre o legislativo e executivo com vistas a assegurar a governabilidade.

A inclusão de dotações à lei orçamentária, por meio de emendas individuais, não assegura suas execuções, pois, para a realização, irão depender de gestões, no tocante à administração financeira e orçamentária sob a responsabilidade do chefe de cada Poder, e, de forma preponderante, do chefe do Poder Executivo. Os parlamentares autores das emendas individuais podem alterar anualmente a destinação de suas proposições de acordo com suas conveniências e, também, para as instituições as quais perceberem maior possibilidade de êxito, na consecução de suas proposições, não existindo o compromisso de assegurar a continuidade de obras anteriormente iniciadas, mediante recursos destinados por suas emendas individuais. As emendas individuais são utilizados como estratégia eleitoral (FIGUEIREDO; LIMONGI, 2005), permitindo que ao viabilizar sua execução, esta constitua em importante ponto na reeleição dos parlamentares.

Analisando o escopo dos tipos considerados nesse estudo, com relação a expectativa de variabilidade orçamentária, é proposta na tabela 2 essa percepção:

Tabela 2 - Expectativa de variabilidade conforme tipos orçamentários

\begin{tabular}{l|l|l}
\hline Tipos & Grupos de despesa & Variabilidade Orçamentária prevista \\
\hline OCK & 3,4 e 5 & $<$ geral e $>$ investimentos \\
\hline Geral & $1,2,3,4,5$ e 6 & $<$ demais \\
\hline
\end{tabular}




\begin{tabular}{l|l|l}
\hline Investimentos & 4 & <emendas individuais e > OCK \\
\hline Emendas individuais & Todos & > demais \\
\hline
\end{tabular}

Fonte: Elaboração própria

\subsubsection{Etapa}

Representam os momentos, no processo orçamentário, ocorridos de forma sequencial. Nesse processo foram identificados os seguintes momentos: Projeto de Lei Orçamentária - PLOA, Dotação Inicial ou Lei aprovada, Dotação autorizada ou atual LOA + créditos, Executado correspondente ao empenhado ou liquidado, Pago no exercício, Restos a Pagar Pagos. A seguir, estão as descrições das etapas, os prazos dos seus transcursos e os principais atores envolvidos:

Tabela 3- Prazos e atores principais das etapas orçamentárias

\begin{tabular}{l|l|l}
\hline Etapa & Prazos & Atores \\
\hline PLOA & $\begin{array}{l}\text { Até o dia 31 de agosto do ano } \\
\text { anterior }\end{array}$ & $\begin{array}{l}\text { Poder Executivo, com } \\
\text { coordenação da SOF/MP }\end{array}$ \\
\hline Lei (Dotação Inicial) & $\begin{array}{l}2^{\circ} \text { período da sessão legislativa } \\
\text { do ano anterior }\left(1^{\circ} \text { de setembro a }\right. \\
22 \text { de dezembro) }\end{array}$ & Poder Legislativo \\
\hline $\begin{array}{l}\text { Autorizado (Dotação Inicial + } \\
\text { créditos adicionais) }\end{array}$ & $\begin{array}{l}\text { No decorrer do exercício da } \\
\text { vigência da LOA }\end{array}$ & $\begin{array}{l}\text { Poder Executivo, com } \\
\text { coordenação da SOF/MP. }\end{array}$ \\
\hline Executado & $\begin{array}{l}\text { No decorrer do exercício da } \\
\text { vigência da LOA }\end{array}$ & $\begin{array}{l}\text { Poder Executivo, com } \\
\text { coordenação da SOF/MP }\end{array}$ \\
\hline Pago & $\begin{array}{l}\text { No decorrer do exercício da } \\
\text { vigência da LOA }\end{array}$ & $\begin{array}{l}\text { Poder Executivo, com } \\
\text { coordenação da STN/MF }\end{array}$ \\
\hline Restos a Pagar Inscritos & $\begin{array}{l}\text { Logo após o término do } \\
\text { exercício de vigência da LOA }\end{array}$ & $\begin{array}{l}\text { Poder Executivo, com } \\
\text { coordenação da STN/MF }\end{array}$ \\
\hline Restos a Pagar Pagos & $\begin{array}{l}\text { Exercício seguinte à vigência da } \\
\text { LOA }\end{array}$ & $\begin{array}{l}\text { Poder Executivo, com } \\
\text { coordenação da STN/MF }\end{array}$ \\
\hline
\end{tabular}

Fonte: Elaboração própria.

Como as variabilidades serão analisadas considerando os momentos, segue uma descrição dos principais fatores que influenciam cada uma das etapas: 


\section{Quadro 4 - Descrição das etapas orçamentárias}

\begin{tabular}{|c|c|}
\hline Etapa & Principais Fatores \\
\hline PLOA & $\begin{array}{l}\text { As discussões são travadas no Congresso Nacional, com prerrogativa } \\
\text { de inserção de emendas a todos os parlamentares, que buscam por } \\
\text { meio da alocação de recursos garantir o atendimento as demandas } \\
\text { que possam conferir visibilidade a sua atuação. Os poderes se } \\
\text { colocam de forma mais acentuada nos relatores geral e setoriais do } \\
\text { PLOA, e no presidente da Comissão Mista de Orçamento - CMO. }\end{array}$ \\
\hline Lei & $\begin{array}{l}\text { As alterações podem acrescentar recursos às dotações a partir do } \\
\text { inicialmente previsto. As alterações abordadas são apenas aquelas } \\
\text { que importam em acréscimos, não sendo computados os } \\
\text { remanejamentos, pois não alteram o total. Nesse momento todo } \\
\text { encaminhamento de créditos adicionais é coordenado pelo MP por } \\
\text { meio da SOF. As solicitações de alterações devem ser aprovadas } \\
\text { pelo Congresso Nacional que não poderá alterar os valores totais. } \\
\text { Assim, o ator mais preponderante nesse estágio é o MP/SOF. }\end{array}$ \\
\hline Autorizado & $\begin{array}{l}\text { Após a aprovação da LOA a execução depende das autorizações de } \\
\text { gasto, que dependem da publicação dos atos de programação } \\
\text { orçamentária e financeira. Essas programações devem seguir o } \\
\text { apurado nas avaliações bimestrais, que poderão apontar a } \\
\text { necessidade de estabelecer limitações de movimentação e empenho, } \\
\text { que restringem a execução das despesas autorizadas na LOA aos } \\
\text { limites estabelecidos. A gestão desses limitações para a fase inicial } \\
\text { das despesas, que é o empenho, é responsabilidade do MP/SOF, e se } \\
\text { constitui em mais um estágio que deve ser percorrido para viabilizar } \\
\text { a execução de despesas. }\end{array}$ \\
\hline Executado & $\begin{array}{l}\text { O empenho permite que a despesa tenha sua execução iniciada. } \\
\text { Porém após o seu início e ao término é feito o pagamento, o qual } \\
\text { dependerá dos limites financeiros, também fixados a partir das } \\
\text { programações financeiras, que não garantem necessariamente que } \\
\text { todas as despesas já empenhadas poderão ser pagas até o final do } \\
\text { exercício. O limite de pagamento ou financeiro, estabelecido } \\
\text { conforme as disponibilidades de caixa, são fixadas pelo MF, com a } \\
\text { coordenação da STN. O limite de pagamento significa que após o } \\
\text { seu início, dentro dos limites de movimentação e empenho, } \\
\text { dependerá dos limites de pagamento para a sua conclusão. Nem } \\
\text { sempre os limites de movimentação e empenho e de pagamento } \\
\text { andam casados. }\end{array}$ \\
\hline Pago & $\begin{array}{l}\text { Os valores pagos referem-se às despesas que após seu início no } \\
\text { exercício (empenho) poderão ser concluídas no mesmo exercício. } \\
\text { Ponto importante é o fato de que o limite financeiro para pagamentos } \\
\text { no exercício destina-se tanto a despesas empenhadas no exercício } \\
\text { como decorrente de exercícios anteriores (restos a pagar). Assim, } \\
\text { existe uma competição entre despesas empenhadas no exercício e } \\
\text { decorrente de restos a pagar quanto a disponibilidade financeira para } \\
\text { que os compromissos sejam finalizados. Valores pagos inferiores aos } \\
\text { empenhados significa que as despesas não concluídas irão integrar } \\
\text { os restos a pagar no exercício subsequente. }\end{array}$ \\
\hline Restos a Pagar Pagos & $\begin{array}{l}\text { A semelhança do ocorrido na fase entre o executado e pago, o } \\
\text { pagamento dos restos a pagar inscritos depende do limite financeiro } \\
\text { definido pelo MF/STN. Caso os restos a pagar inscritos não venham } \\
\text { a ser pagos no prazo de sua validade, que normalmente é de dois } \\
\text { anos, seu cumprimento poderá ser pago posteriormente à conta de } \\
\text { despesas de exercícios anteriores, mas dependerá de dotação } \\
\text { orçamentária ou por via judicial. Qualquer prorrogação no } \\
\text { pagamento significa que o recebimento das despesas realizadas irá } \\
\text { apresentar um atraso sensível. }\end{array}$ \\
\hline
\end{tabular}

FONTE: Elaboração própria, a partir da legislação do processo orçamentário 
Assim, as etapas serão consideradas como os momentos entre os marcos do processo orçamentário denominados:

Congresso = LOA / PLOA. Representa as mudanças introduzidas pelo Congresso Nacional, com sanção do Presidente da República.

SOF1 = Autorizado / LOA. Identifica as variações decorrentes dos créditos adicionais editados ao longo do exercício e que alteraram o perfil das autorizações de gastos.

SOF2 = Executado / Autorizado. Qualifica as autorizações de gastos empregadas ao longo do exercício.

STN1 = Pago / Autorizado. Expressa as variações de agenda relacionadas aos acordos adimplidos de maneira imediata em relação às autorizações utilizadas.

STN2 = Restos a pagar pagos / Pago. Indica a relação entre o adimplemento de acordos diferidos e os solvidos no exercício

\subsection{Análise de clusters}

Para identificação dos grupos de unidades orçamentárias que apresentam padrões de comportamento similar, conforme os tipos de despesa e as etapas orçamentárias, foi adotada a análise de clusters como método de análise e avaliação dos pressupostos da presente pesquisa. A análise de clusters refere-se ao processo de encontrar grupos de pontos, em uma base de dados, que de alguma forma estão juntos (JANERT, 2011).

Ainda de acordo com Janert (2011), a análise de clusters é um método exploratório para descobrir estruturas em um conjunto de dados. No entanto, a definição não é suficiente, pois devem os clusters terem suas separações bem identificadas, importando que, em um conjunto de dados, não basta determinados pontos estarem mais próximos de 
uns do que de outros. Assim, clusters são regiões contíguas de alta incidência de pontos separada por regiões de baixa densidade de pontos.

Os métodos de análises de clusters permitem diferentes medidas de distâncias, entre os pontos ou dados, para determinar as semelhanças entre essas observações. Os clusters podem ter diferentes formas e formatos, existindo diversos métodos de análise de clusters que servem para problemas e abordagens específicos, conforme os bancos de dados e os propósitos das análises. No intuito de encontrar a melhor descrição dos clusters relacionados às variabilidades orçamentárias, decidiu-se utilizar alguns métodos para comparar os seus resultados. Os métodos propostos a serem utilizados foram os clusters hierarquizados singlelinkage, averagelinkage, completelinkage e wardslinkage. Seguem as suas características. A utilização dos clusters median e centroid foi excluída, por não apresentarem dendogramas de distribuição hierárquica dadas as inversões (EVERITT; LANDAU; LEESE; STAHL, 2011).

\subsubsection{Singlelinkage}

Os clusters são determinados pelas observações mais próximas entre dois grupos. Os clusters single possuem tendência a produzir clusters não balanceados, especialmente com base de dados grande, e não leva em consideração a estrutura dos clusters (EVERITT; LANDAU; LEESE; STAHL, 2011). Também mencionado como o vizinho mais perto (nearest neighbour).

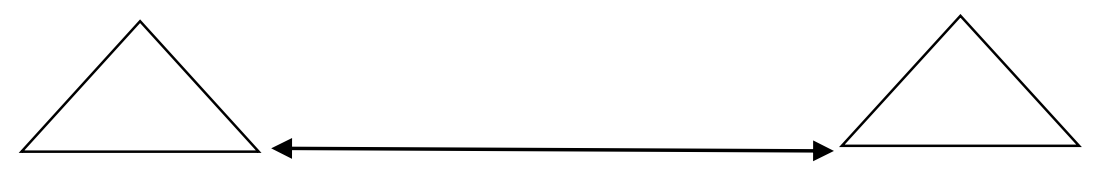




\section{Figura 5: distância entre clusters - singlelinkage}

Fonte: Everitt et al (2011)

\subsubsection{Averagelinkage}

A distância entre os grupos é medida pela média de cada um deles. É intermediário entre o single e o complete, pois assim como o single trata da mínima distância entre pares de objetos, e o complete a máxima distância, o average trata a distância pela média. Todavia, difere deles, por considerar os relacionamentos entre todos os pontos. O average tende a juntar clusters com pequena variância, levando em consideração sua estrutura e são relativamente robustos os agrupamentos identificados (EVERITT; LANDAU; LEESE; STAHL, 2011).
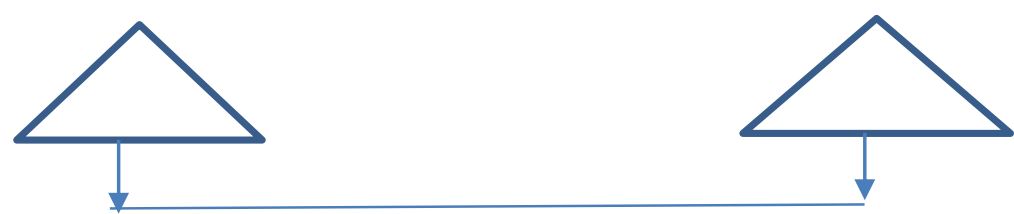

Figura 6: distância entre os clusters - Averagelinkage.

Fonte: Everitt et al (2011)

\subsubsection{Completelinkage}

A proximidade entre dois grupos é determinada pelos pontos mais distantes entre esses grupos. Conhecido como o vizinho mais distante (furthest neighbour), tende a produzir clusters compactos com diâmetros equivalentes, e não leva em consideração a estrutura dos clusters (EVERITT; LANDAU; LEESE; STAHL, 2011).

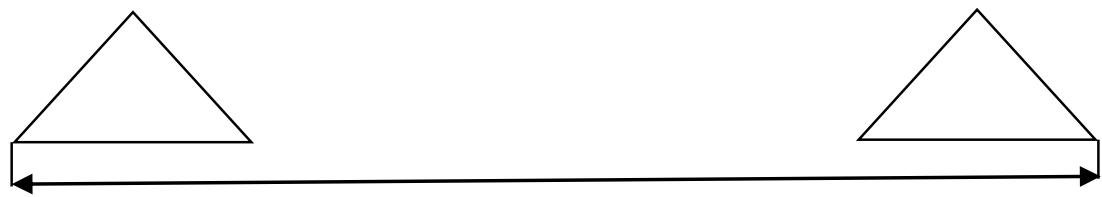




\section{Figura 7: distância entre clusters - completelinkage}

Fonte: Everitt et al (2011)

\subsubsection{Wardslinkage}

Refere-se à aplicação do método de Ward, que mede a distância entre dois clusters em termos de redução da coerência, quando há a combinação de dois clusters. A coerência, nesse caso, considera a junção de dois clusters próximos e de dois distantes. São sensíveis aos outliers e tendem a encontrar clusters do mesmo tamanho e esféricos.

\subsection{Hipóteses}

No intuito da verificação dos pressupostos da pesquisa, foram formuladas algumas hipóteses no intuito de servirem como instrumento para avaliação dos pressupostos teóricos e abordando situações com diferentes graus de variação dentro dos grupos considerados no presente estudo. As hipóteses propostas consideram do grau de variabilidade orçamentária entre os grupos que a integram

3.3.1 Hipótese 1 - tipos: Emendas individuais > grupo investimentos > grupo outros custeios e capital > grupo despesas totais

Algumas análises (FIGUEIREDO; LIMONGI, 2008) trataram do aspecto volátil das emendas parlamentares, particularmente das emendas individuais que oscilam conforme o desejo discricionário de cada parlamentar, não existindo restrições a livre alocação desses recursos. De forma semelhante, foi observado o comportamento dos gastos com investimentos, de característica não compulsória, como dependente 
estritamente da vontade do executor da política em cada área setorial. Assim, pode-se depreender a partir desses estudos (FIGUEIREDO; LIMONGI, 2008) que o grau de execução de ambos os grupos de despesa (emendas individuais e investimentos) é altamente discricionário, porém as decisões que envolvem as emendas individuais estão mais espalhadas dentro de critérios personalísticos, ocorrendo maior oscilação de acordo com os ajustes decorrentes da gestão do presidencialismo de coalizão.

Quanto aos outros grupos de despesa considerados, o grupo de outras despesas correntes e capital (OCK), apesar de grande parte discricionário, apresenta um grau considerável de gastos obrigatórios como benefícios assistenciais e previdenciários, representado uma mescla de faculdade e obrigação na execução da despesa pública. As despesas totais, integradas majoritariamente por despesas com pessoal e pagamentos dos serviços da dívida, ambos compulsórios em sua execução, apresenta a expectativa de uma menor variabilidade orçamentária, haja vista estarem constituídas majoritariamente por gastos obrigatórios, porém incluem todos os grupos anteriores.

Assim, para a formação da Hipótese 1 é considerado que o grau de variação tende a ser maior quanto maior a discricionariedade do grupo de despesa. Além da confirmação da proposição, a verificação dessa hipótese permitirá compreender se determinadas inferências são aplicadas ao orçamento como um todo, ou há formas diferenciadas conforme as categorias de despesas.

\subsubsection{Hipótese 2 - ano: anos pares > anos ímpares}

A hipótese da variabilidade dos anos pares superior aos anos ímpares decorre do Political Budget Cycle (SHI; SVENSSON, 2003). Assim, em anos eleitorais, as oscilações orçamentárias decorrentes do ciclo eleitoral, e, por conseguinte, dos interesses políticos, seriam maiores. Como as eleições ocorrem sempre em anos pares e há 
interferência do governo federal nos níveis subnacionais, supõe-se nesses exercícios (anos pares) uma maior variabilidade em relações aos anos ímpares.

3.3.3 Hipótese 3 - tipo unidade orçamentária: administração indireta > administração direta> fundos contábeis

As unidades orçamentárias podem ser identificadas quanto a sua natureza. $\mathrm{O}$ Decreto-lei no 200 , de 1967, foi um marco no estabelecimento da descentralização na Administração Pública, conferindo a algumas entidades responsáveis por determinadas atribuições maior flexibilidade para o desempenho de suas competências, conforme o interesse público, e ampliando as instituições que passaram a integrar a sua Administração indireta.

Considerando as instituições sob ótica da flexibilidade, supõe-se que as entidades da Administração indireta, como as empresas estatais e autarquias, são mais propensas a ajustes no decorrer do processo, o que pode ser entendido com mais sujeitas a variabilidade orçamentária. Tendo em vista o fato de os fundos serem constituídos basicamente de recursos vinculadas, são esperadas menores alterações e variações ao longo de sua execução, face a definição de sua destinação integrar a natureza de sua criação.

3.3.4 Hipótese 4 - etapas: congresso > sof $1>\operatorname{sof} 2>\operatorname{stn} 1>\operatorname{stn} 2$

Nesse grupo observa-se a sequência do processo orçamentário, no qual acreditase que o grau de variabilidade decresce a partir da redução dos atores e da consolidação dos acordos. Assim, considera-se que os custos transacionais mais elevados encontrar-seiam no início do processo, na discussão perante o Poder Legislativo, até mesmo por se 
tratar de um momento mais aberto e sujeito a interferências. Acrescente-se que as maiores oscilações nos acordos decorrentes do presidencialismo de coalizão estariam sendo observadas nesse momento inicial.

\section{4 - Base de dados}

São 14.550 observações dos valores históricos atribuídos a cada unidade orçamentária, relativos a projeto de lei, lei, autorizado, executado, pago e restos a pagar pagos. Cada valor corresponde ao percentual de participação relativa atribuída à unidade, por tipo, etapa e ano, no período de 2002 a 2012. Assim, a variação examinada (ve) entre as respectivas etapas do devido processo orçamentário é dada pela expressão ve $=$ $\left(\right.$ participação relativa $\left._{\text {uo,tipo,etapa,ano }}\right) /\left(\right.$ participação relativa $\left.a_{\text {uo,tipo,etapa-1,ano }}\right)$ - 1. Para evitar divisões por zero, os valores históricos correspondentes a zero receberam o valor 0,01 , a menor unidade monetária. 


\section{DESCRIÇÃO E ANÁLISE DOS DADOS}

\subsection{Observações por unidade orçamentária, tipo, etapa e ano}

As unidades orçamentárias representam a entidades responsáveis pela aplicação de recursos públicos, podendo tratar-se de unidades com personalidade jurídica ou não. O quantitativo de unidades orçamentárias ao longo dos exercícios apresentou tendência de crescimento. A tendência de crescimento pode decorrer, dentre outros fatores, da criação de fundos, com a expectativa de assegurar recursos específicos para determinadas finalidades. Também se busca maior autonomia, além de a criação de certas entidades, a partir de cisões, conferir maior transparência de atuação. Para determinadas entidades, a identificação por meio de uma unidade orçamentária permite condições de reivindicar maiores recursos para sua programação, e independência na definição da aplicação desses recursos.

\section{Figura 8-Quantidade de unidades orçamentárias}

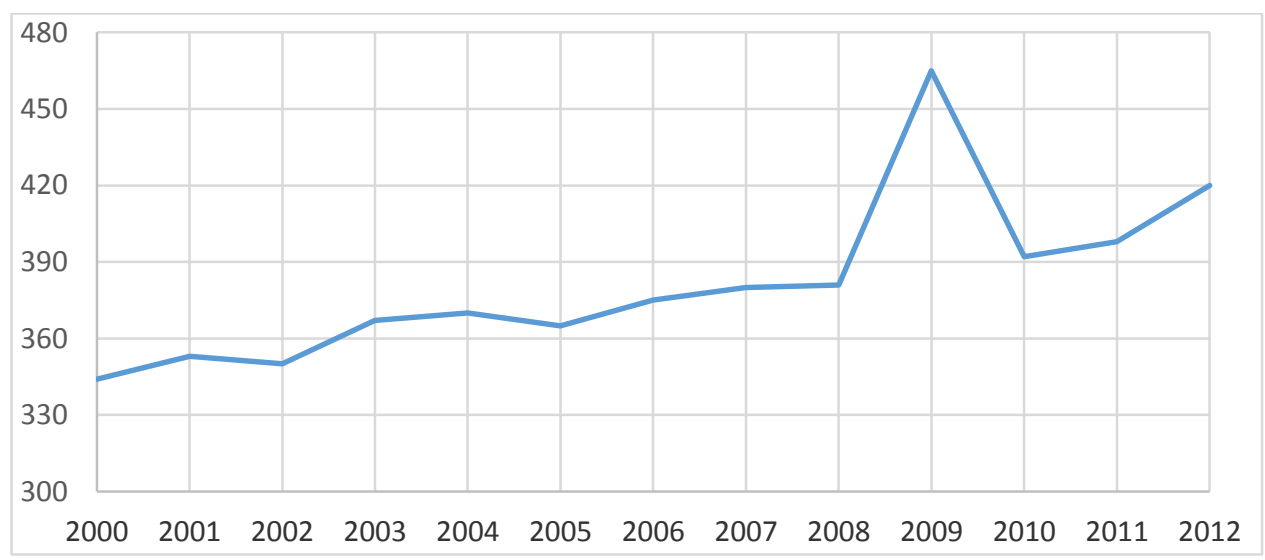

Fonte: Elaboração própria. 
Tabela 5 - distribuição das observações por ano

\begin{tabular}{|c|r|r|r|}
\hline ano & frequência & \multicolumn{1}{|l|}{ percentual } & \multicolumn{1}{l|}{ cumulativo } \\
\hline $\mathbf{2 0 0 2}$ & 1.130 & 7,77 & 7,77 \\
\hline $\mathbf{2 0 0 3}$ & 1.165 & 8,01 & 15,77 \\
\hline $\mathbf{2 0 0 4}$ & 1.216 & 8,36 & 24,13 \\
\hline $\mathbf{2 0 0 5}$ & 1.193 & 8,20 & 32,33 \\
\hline $\mathbf{2 0 0 6}$ & 1.243 & 8,54 & 40,87 \\
\hline $\mathbf{2 0 0 7}$ & 1.256 & 8,63 & 49,51 \\
\hline $\mathbf{2 0 0 8}$ & 1.272 & 8,74 & 58,25 \\
\hline $\mathbf{2 0 0 9}$ & 1.474 & 10,13 & 68,38 \\
\hline $\mathbf{2 0 1 0}$ & 1.578 & 10,85 & 79,22 \\
\hline $\mathbf{2 0 1 1}$ & 1.487 & 10,22 & 89,44 \\
\hline $\mathbf{2 0 1 2}$ & 1.536 & 10,56 & 100,00 \\
\hline Total & $\mathbf{1 4 . 5 5 0}$ & $\mathbf{1 0 0 , 0 0}$ & \\
\hline
\end{tabular}

Fonte: Elaboração própria

A alteração mais acentuada, em 2009, decorreu da mudança de código de algumas unidades orçamentárias do Ministério da Educação. Naquele ano, as atividades de uma mesma unidade orçamentária foram contabilizadas sob dois códigos distintos.

Essas unidades podem ser agregadas em Administração direta, Administração indireta, fundos contábeis e reserva de contingência, cuja distribuição está na Tabela 6.

Tabela 6 - distribuição das observações por espécie de unidade orçamentária

\begin{tabular}{|l|r|r|r|}
\hline unidade orçamentária & frequência & \multicolumn{1}{|c|}{$\%$} & \% cumulativo \\
\hline Adminis tração indireta & 8.176 & 56,19 & 56,19 \\
\hline Administração direta & 4.692 & 32,25 & 88,44 \\
\hline Fundos & 1.672 & 11,49 & 99,93 \\
\hline Reserva de Contingência & 10 & 0,07 & 100,00 \\
\hline Total & $\mathbf{1 4 . 5 5 0}$ & $\mathbf{1 0 0 , 0 0}$ & \\
\hline
\end{tabular}

Fonte: Elaboração própria 
Considerando a divisão por poderes, o estudo distingue as unidades orçamentárias que constituem os chamados órgãos virtuais, geridos pelo Executivo e estabelecidos com a finalidade de detalhar transferências obrigatórias e despesas financeiras (Tabela 7).

Tabela 7- Distribuição das unidades orçamentárias por Poder de Estado

\begin{tabular}{|l|r|r|r|}
\hline Poder & frequência & \multicolumn{1}{|c|}{$\%$} & \% cumulativo \\
\hline Executivo & 11.389 & 78,27 & 78,27 \\
\hline Judiciário & 2.305 & 15,84 & 94,12 \\
\hline Órgãos virtuais & 566 & 3,89 & 98,01 \\
\hline Legislativo & 280 & 1,92 & 99,93 \\
\hline Reserva de Contingência & 10 & 0,07 & 100,00 \\
\hline Total & $\mathbf{1 4 . 5 5 0}$ & $\mathbf{1 , 9 9}$ & \\
\hline
\end{tabular}

Fonte: Elaboração própria

Por tipo de análise, as observações estão distribuídas na forma da Tabela 8, que evidencia o reduzido número de unidades orçamentárias objeto de emendas parlamentares.

Tabela 8 - distribuição das observações por tipo

\begin{tabular}{|l|r|r|r|}
\hline totais & 4.580 & 31,48 & 31,48 \\
\hline ock & 4.361 & 29,97 & 61,45 \\
\hline inves timentos & 3.983 & 27,37 & 88,82 \\
\hline emendas & 1.626 & 11,18 & 100,00 \\
\hline total & $\mathbf{1 4 . 5 5 0}$ & $\mathbf{1 0 0 , 0 0}$ & \\
\hline & & & \\
\hline
\end{tabular}

Fonte: Elaboração própria

\subsection{Geração dos Clusters}


Foram utilizados para verificação da constituição de grupos, conforme a variabilidade orçamentária, os seguintes tipos de cluster: single, complete, average, e Ward. O propósito da utilização desses tipos de clusters é verificar no primeiro momento o comportamento a partir de uma análise conjunta desses clusters, evitando uma predominância de um tipo em uma abordagem inicial. Para a descrição posterior dos padrões orçamentários deverá ser escolhido aquele que apresentou-se de forma mais equilibrada entre os quatro tipos inicialmente aplicados.

\subsection{1 $1^{\mathrm{a}}$ etapa da geração dos clusters}

A primeira geração dos clusters apresentou raiz majoritária, com a quase totalidade das observações. A partir dessa verificação, foi adotada como estratégia analítica a percepção de geração de novas rodadas dos clusters single, complete, average e Ward, a partir das raízes principais. Assim, foi definida a marcação da raiz, a partir do número de grupos anterior à situação na qual a divisão ocorreu fora da raiz principal.

Esse procedimento analítico possibilitou a obtenção de uma visão das camadas orçamentárias para posterior descrição dos padrões verificados. Assim, os pontos identificados fora da raiz principal foram excluídos, mediante sucessivas rodadas de exclusões da raiz principal. O objetivo é a geração de tantas rodadas quantas necessárias até chegar o momento em que a raiz principal apresente número de observações insignificante em relação ao inicialmente considerado.

Essa estratégica metodológica analítica permite visualizar os pontos mais fora da curva, e distantes dos padrões hegemônicos identificados no orçamento. Assim, utilizouse essa análise para identificar quais tipos, instituições e etapas apresentaram maior variabilidade comparativamente. Os gráficos exemplificam a aplicação desse critério. 
Figura 9 - dendogramas por grupos para marcação das rodadas
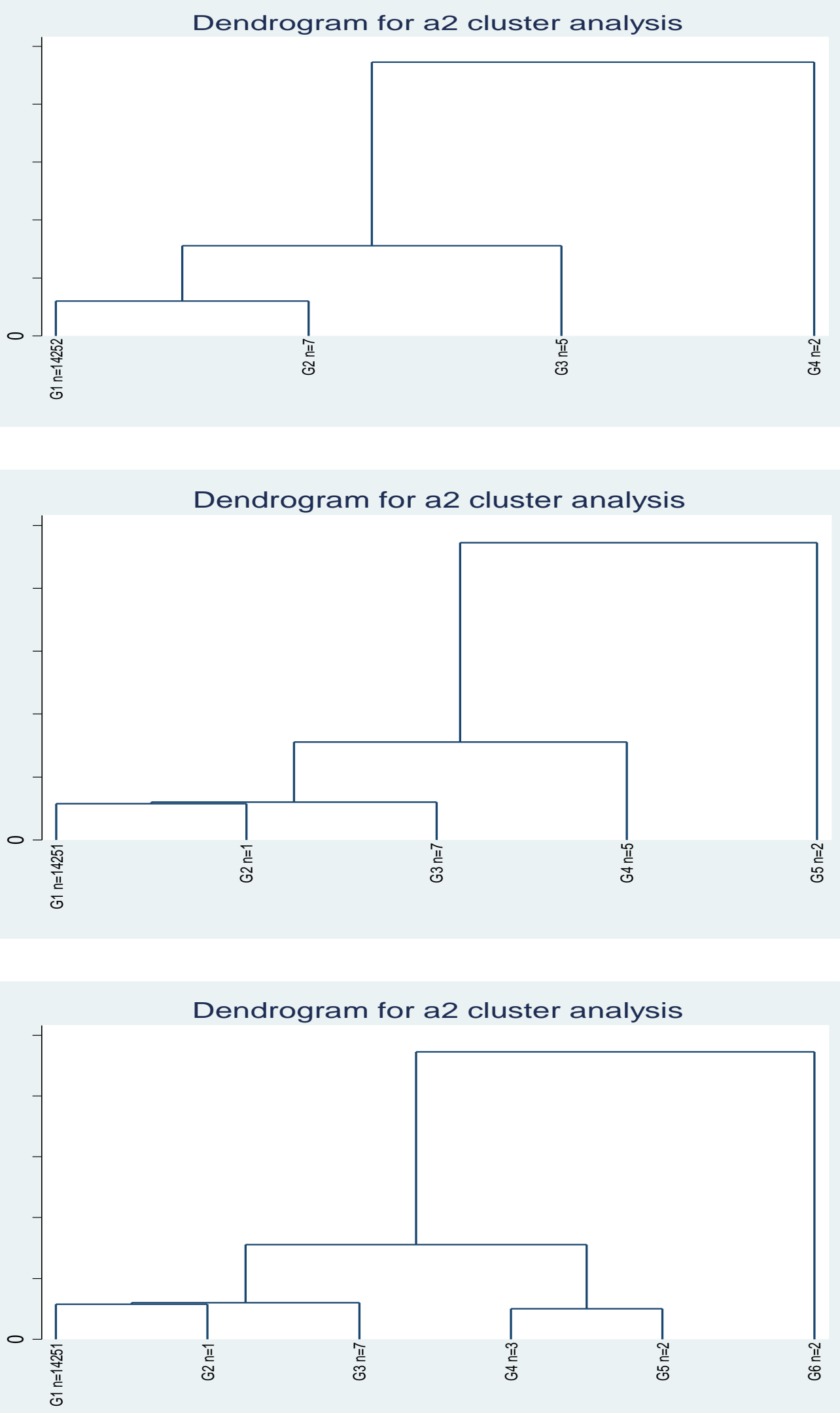

Fonte: Elaboração própria 
A partir da distribuição em 6 grupos, a divisão ocorre fora da raiz principal, sendo que anteriormente todos os grupos tinham se formado a partir dessa raiz majoritária. Por conseguinte, a divisão em grupos ocorre, no momento em que a última ocorrência da divisão ainda era observada na principal raiz, com marcação desse grupo majoritário. O primeiro grupo (G1) assinalado, quando da divisão em 5 grupos, seguiu para a próxima rodada. Nesse caso, do cluster (average), seria um total de 14.251 observações.

Contudo, tal procedimento foi aplicado a todos os clusters nos quais foi possível a visualização dos dendogramas (single, complete, average e Ward), sendo que em cada rodada eram descartadas as observações identificadas a partir do critério destacado. Os comportamentos dos clusters não eram regulares, quanto ao número de observações descartadas e número de raízes para verificação da primeira divisão fora da raiz principal. A tabela ilustra os resultados, a partir da metodologia aplicada.

Tabela 9 - Observações por rodada

\begin{tabular}{|l|l|l|l|}
\hline Rodada & quantidade de observações & observações excluídas & \% \\
\hline 1 & 14.550 & 284 & 1,95 \\
\hline 2 & 14.266 & 332 & 2,33 \\
\hline 3 & 13.934 & 54 & 0,39 \\
\hline 4 & 13.880 & 186 & 1,34 \\
\hline 5 & 13.694 & 224 & 1,64 \\
\hline 6 & 13.470 & 368 & 2,73 \\
\hline 7 & 13.102 & 248 & 1,89 \\
\hline 8 & 12.854 & 30 & 0,23 \\
\hline 9 & 12.824 & 45 & 0,35 \\
\hline 10 & 12.779 & 5 & 0,04 \\
\hline 11 & 12.774 & 35 & 0,27 \\
\hline $12^{\mathbf{o}}$ & 12.739 & 913 & 7,17 \\
\hline 13 & 11.826 & 1.567 & 13,25 \\
\hline 14 & 10.259 & 1.057 & 10,30 \\
\hline 15 & 9.202 & 2.573 & 27,96 \\
\hline 16 & 6.629 & 2.836 & 42,78 \\
\hline 17 & 3.793 & 1.814 & 47,82 \\
\hline 18 & 1.979 & 1.943 & 98,18 \\
\hline 19 & 36 & & \\
\hline
\end{tabular}

Fonte: Elaboração própria 
Observa-se que até a $12^{\mathrm{a}}$ rodada os descartes foram inferiores a $3 \%$, sendo na maior parte das rodadas inferior a $2 \%$. Tal fato sugere que, aparentemente, até a Rodada 12, os descartes eram, basicamente, outliers, pontos esparsos fora da variação comum da maioria das situações verificadas no orçamento público federal. A figura 10 ilustra o número de observações, em cada rodada, pelas barras, e o número de observações descartadas, pela linha.

\section{Figura 10 - Observações x rodadas de clusters}

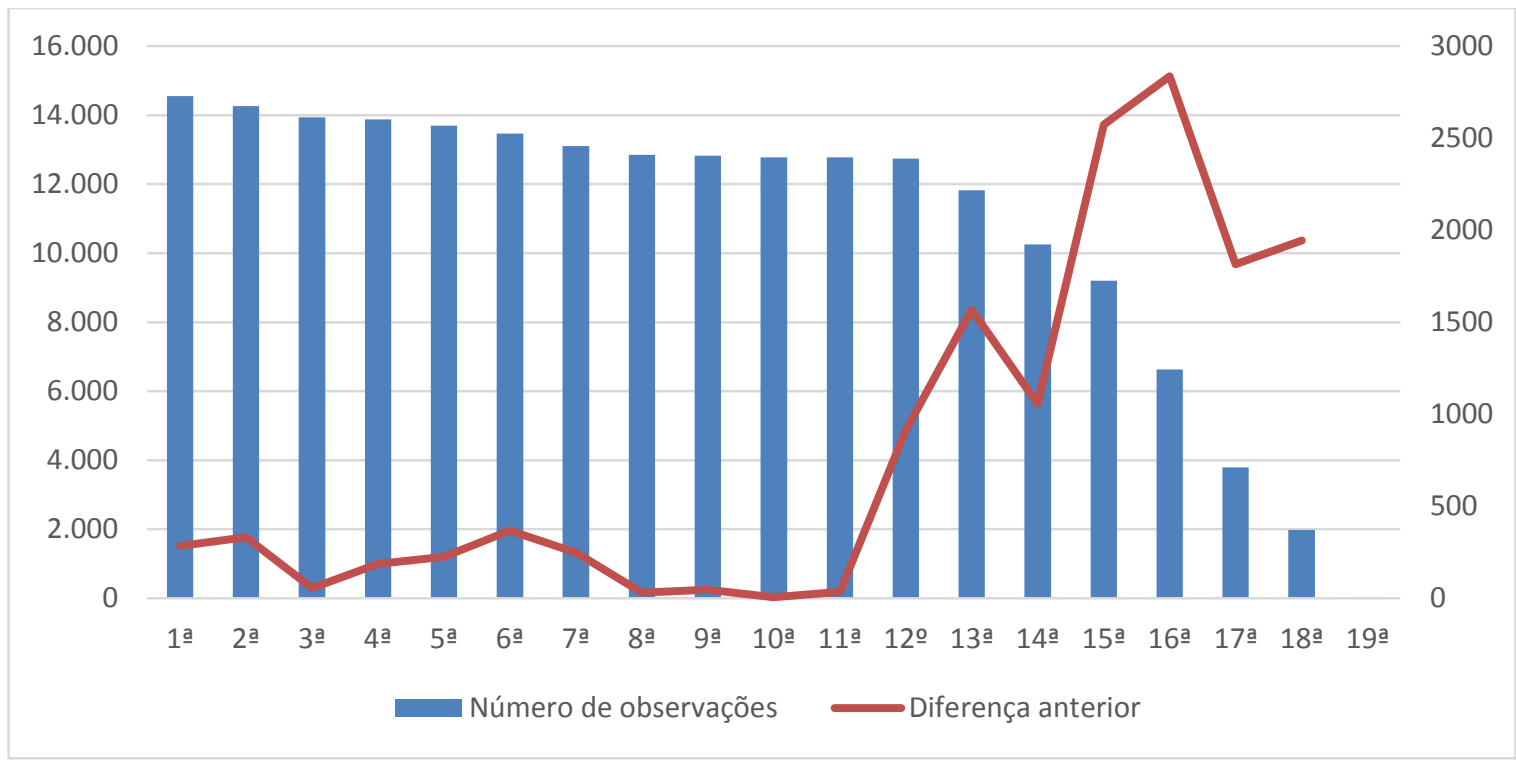

Fonte: Elaboração própria

A representação gráfica permite identificar que a variabilidade do orçamento público ocorre em camadas, com pontos fora da curva. Essa análise do comportamento da variabilidade orçamentária sugere diferentes padrões, descrevendo o que podem vir a ser consideradas leis empíricas do orçamento federal brasileiro, na linha de autores como Wildavsky (1966) e o incrementalismo, e Jones (2009) e o equilíbrio pontuado. O ponto de corte da mudança mais acentuada nas exclusões ocorreu na $12^{\mathrm{a}}$ rodada, que será utilizada na referência para análise das variabilidades entre os grupos de despesa. 


\subsubsection{Tipo}

O comportamento das exclusões, conforme os tipos de despesas, não se apresentou de forma uniforme, destacando-se que a maior parte dos outliers ocorreram no grupo das emendas parlamentares individuais, e de forma bem mais acentuada $(48,40 \%)$. Posteriormente, o grupo dos gastos com investimentos apresentou maior exclusão percentual $(9,82 \%)$, seguido dos gastos que incluem todos os grupos de despesa (7,36\%), e finalmente outros gastos de custeio e de capital - OCK $(6,79 \%)$.

Tabela 10 - exclusões por tipo de despesa e rodada (acumulativo)

\begin{tabular}{|l|r|r|r|r|r|}
\hline \multicolumn{1}{|c|}{ Tipos/rodadas } & \multicolumn{1}{c|}{ OCK } & \multicolumn{1}{c|}{ Investimentos } & \multicolumn{1}{c|}{ Todos } & \multicolumn{1}{c|}{ Emendas } & \multicolumn{1}{l|}{ Totais } \\
\hline 1 & 258 & 0 & 24 & 284 \\
\hline 2 & 262 & 257 & 76 & 21 & 616 \\
\hline 3 & 268 & 264 & 85 & 53 & 670 \\
\hline 4 & 276 & 321 & 167 & 92 & 856 \\
\hline 5 & 285 & 335 & 180 & 280 & 1080 \\
\hline 6 & 288 & 348 & 261 & 551 & 1448 \\
\hline 7 & 288 & 358 & 266 & 784 & 1696 \\
\hline 8 & 289 & 363 & 289 & 785 & 1726 \\
\hline 9 & 291 & 364 & 331 & 785 & 1771 \\
\hline 10 & 291 & 365 & 334 & 786 & 1776 \\
\hline 11 & 296 & 391 & 337 & 787 & 1811 \\
\hline $12^{\circ}$ & 901 & 684 & 345 & 794 & 2724 \\
\hline 13 & 1816 & 1265 & 393 & 817 & 4291 \\
\hline 14 & 2366 & 1669 & 476 & 837 & 5348 \\
\hline 15 & 3400 & 2651 & 958 & 912 & 7921 \\
\hline 16 & 3959 & 3518 & 2126 & 1154 & 10757 \\
\hline 17 & 4195 & 3640 & 3540 & 1196 & 12571 \\
\hline
\end{tabular}

Fonte: Elaboração própria

O gráfico das exclusões por tipos de despesa permite visualizar que após a $12^{\mathrm{a}}$ rodada, as exclusões de OCK e investimentos passam a ocorrer mais acentuadamente, e após a $16^{\mathrm{a}}$ rodada os gastos envolvendo todos os grupos de despesa entram em trajetória ascendente. 


\section{Figura 11 - exclusões por tipo de despesa e por rodada}

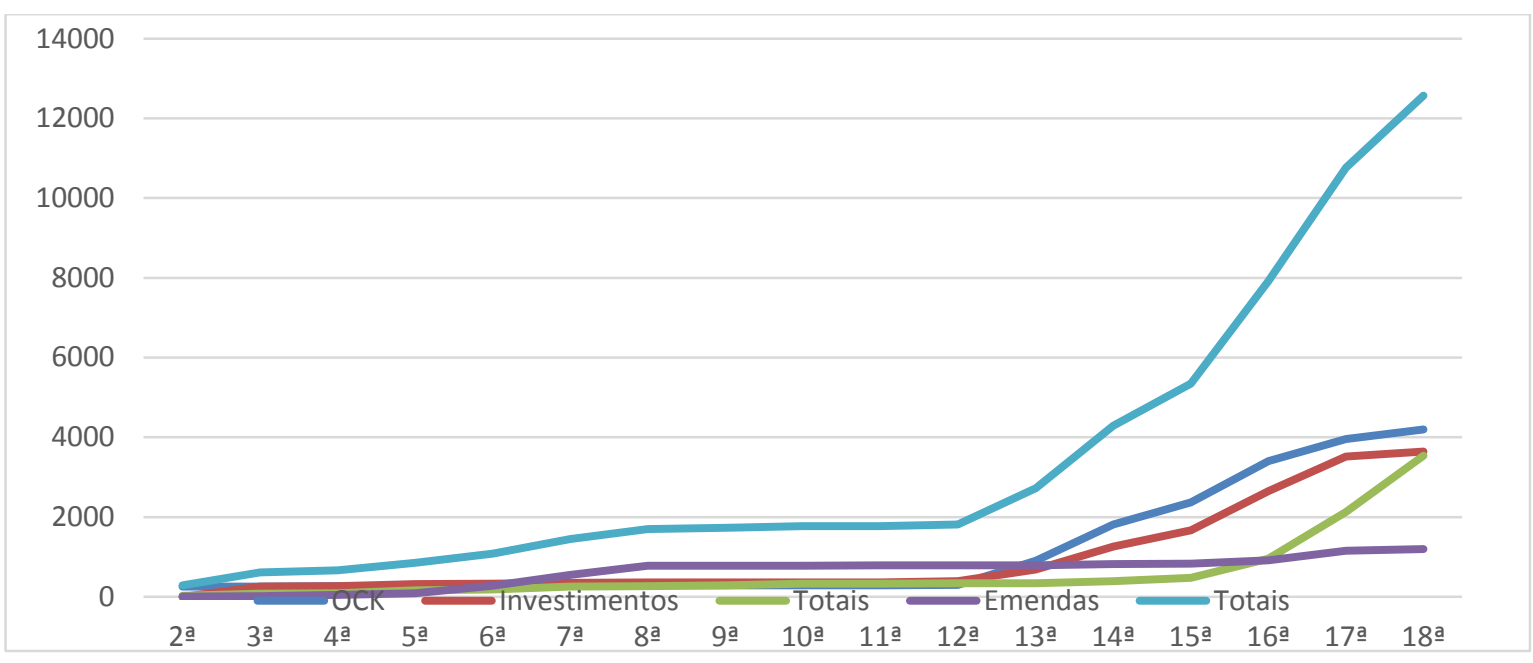

Fonte: Elaboração própria

Consideradas as exclusões ocorridas, até a $12^{\mathrm{a}}$ rodada, sua incidência foi verificada, mais acentuadamente, nos gastos referente a emendas parlamentares individuais, conforme expresso na tabela 11. Esses achados estão alinhados com parte da Hipótese 1, que considerava a variabilidade na seguinte ordem: emendas > investimentos $>$ OCK > gastos totais.

Tabela 11 - exclusões por tipo e percentual até $12^{\mathrm{a}}$ rodada

\begin{tabular}{crrrrr}
\hline \multicolumn{1}{c}{ Tipos } & Emendas & Investimentos & Todos & OCK & TOTAL \\
\hline Observações & 1.626 & 3.983 & 4.580 & 4.361 & 14.550 \\
Exclusões & 787 & 391 & 337 & 296 & 1811 \\
\hline \% & $\mathbf{4 8 , 4 0}$ & $\mathbf{9 , 8 2}$ & $\mathbf{7 , 3 6}$ & $\mathbf{6 , 7 9}$ & $\mathbf{1 2 , 4 5}$ \\
\hline
\end{tabular}

Fonte: Autor

Os apontamentos confirmam que as emendas possuem maior variabilidade, e que, sequencialmente, o grupo de investimentos seria aquele com maior variação percentual, seguido dos gastos totais e por último o grupo de OCK, ficando descrito da seguinte forma: emendas $>$ investimentos $>$ gastos totais $>$ OCK

Esse indicativo aponta na direção que os gastos totais, quando comparados com OCK, que incluem despesas com pessoal e serviço da dívida, não apresentam uma rigidez 
irretocável, apesar de tratar-se de gastos compulsórios, demonstrando que ocorrem ajustes no decorrer do exercício.

\subsubsection{Ano}

A evolução das observações ao longo dos exercícios é coerente com o aumento do número de unidades orçamentárias, decorrendo de cisões e criações de novas instituições, até classificações para melhor identificação das despesas, como o caso dos órgãos virtuais.

A tabela 12 demonstra que as exclusões até a $12^{\mathrm{a}}$ rodada foram percentualmente maiores nos anos de 2009 em diante, com um pico em 2010, demonstrando uma maior incidência dos pontos fora da curva nesse período. Nos anos anteriores as exclusões ficaram abaixo da média. Chama a atenção o fato de 2010 ser um ano eleitoral, em que se elegeu a Presidenta Dilma Rousseff.

Tabela 12 - Observações e exclusões por ano e na $12^{\mathrm{a}}$ rodada.

Fonte: Elaboração própria

\begin{tabular}{|c|c|c|c|}
\hline Ano & Observações & Até $12^{\mathrm{a}}$ rodada & $\%$ \\
\hline 2002 & 1.130 & 99 & 8,76 \\
\hline 2003 & 1.165 & 130 & 11,16 \\
\hline 2004 & 1.216 & 87 & 7,15 \\
\hline 2005 & 1.193 & 63 & 5,28 \\
\hline 2006 & 1.243 & 80 & 6,44 \\
\hline 2007 & 1.256 & 81 & 6,45 \\
\hline 2008 & 1.272 & 122 & 9,59 \\
\hline 2009 & 1.474 & 237 & 16,08 \\
\hline 2010 & 1.578 & 388 & 24,59 \\
\hline 2011 & 1.487 & 281 & 18,9 \\
\hline 2012 & 1.536 & 243 & 15,82 \\
\hline Total & 14.550 & 1811 & 12,45 \\
\hline
\end{tabular}

A Figura 11 ilustra a distribuição por ano e rodada, cuja maior participação percentual nas primeiras rodadas ocorreu, no exercício de 2010; sendo que após a $12^{\mathrm{a}}$ a 
participação aproxima-se da equivalência entre os exercícios. Compreendendo que as primeiras rodadas representam a identificação dos pontos mais fora da curva, merece atenção a análise de fatos que ocorreram no ano de 2010, como sugestão de futuro estudo.

\section{Figura 12 - Exclusões por ano e rodada}

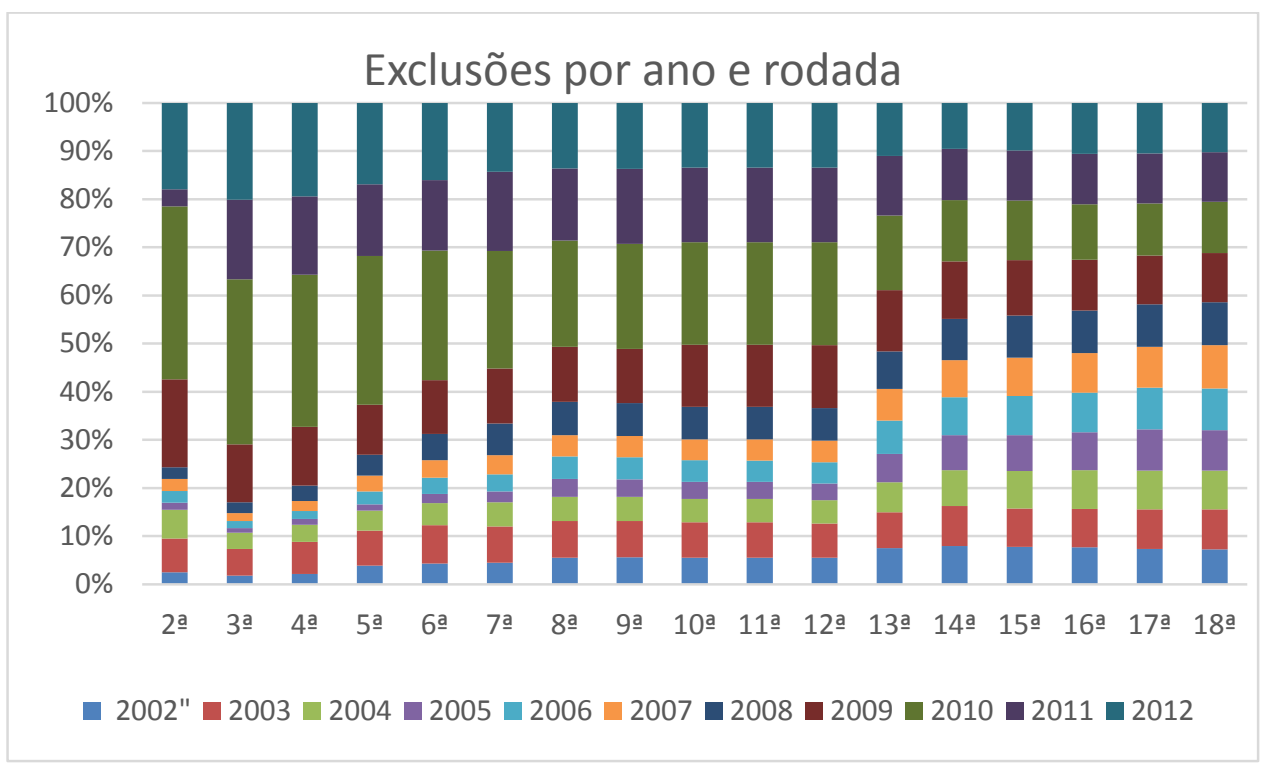

Fonte: Elaboração própria

A Hipótese 2, considerada a partir do $P B C$, afirma que as variações em anos eleitorais são superiores a anos não eleitorais. Nesse sentido a suposição é que a variação em anos pares, coincidentes com a data da realização de eleições ora federais e estaduais, ora municipais, deveriam ser superiores aos anos ímpares, nos quais não há eleições gerais previstas. Todavia, os resultados não indicam tal fato como uma situação regular e previsível; pois, apenas no exercício de 2010 ocorreu uma maior verificação de variação. Considerando que a expectativa de maior impacto pudesse ter sua ocorrência, nas eleições federais e estaduais, nos anos de 2002, 2006 e 2010, a maior contundência para reforçar a afirmação do PBC só foi encontrada no período da transição do governo Lula para o governo Dilma. 
Fato identificado é o maior número de casos, após 2009. Aos olhos do presidencialismo de coalizão (ABRANCHES, 1988), a partir daí, o orçamento público aparentemente passou a ser um instrumento mais presente e efetivo para assegurar a maioria das coligações governamentais.

\subsubsection{Unidade Orçamentária}

A avaliação de acordo com o tipo institucional, demonstrou que, as unidades orçamentárias pertencentes a Administração indireta, tais como autarquias, empresas estatais e fundações, apresentaram o maior percentual de observações desviantes em relação ao aparente padrão observado. Na tabela 13 estão descritos os percentuais de exclusão de cada tipo de unidade orçamentária até a $12^{\mathrm{a}}$ rodada, referência nesse estudo.

Tabela 13 - exclusões por tipo de unidade orçamentária e rodada

\begin{tabular}{|c|c|c|c|c|c|}
\hline unidade orçamentária & $\begin{array}{l}\text { Administração } \\
\text { direta }\end{array}$ & $\begin{array}{l}\text { Administração } \\
\text { indireta }\end{array}$ & Fundos & $\begin{array}{c}\text { Reserva de } \\
\text { Contingência }\end{array}$ & Total \\
\hline Observações & 4.692 & 8.176 & 1.672 & 10 & 14.550 \\
\hline Exclusões até $12 \mathrm{a}$ rodada & 347 & 1.222 & 242 & - & 1.811 \\
\hline$\%$ & 7,40 & 14,95 & 14,47 & 0,00 & 12,45 \\
\hline
\end{tabular}

Fonte: Elaboração própria a partir da descrição dos dados das unidades orçamentárias e Stata 12.

Chama a atenção o fato de os fundos apresentarem um comportamento desviante, assumindo patamar de variação próximo ao das entidades da Administração indireta, haja vista serem unidades orçamentárias constituídas por recursos vinculados, o que levaria a supor menor discricionariedade das aplicações, e, assim, comportamento mais homogêneo.

Semelhantemente a outras classificações, a partir da $12^{\mathrm{a}}$ rodada, as variabilidades apresentam-se mais uniformemente distribuídas entre os tipos de unidades orçamentárias. 


\section{Figura 13 - observações por tipo de unidade orçamentária e rodada}

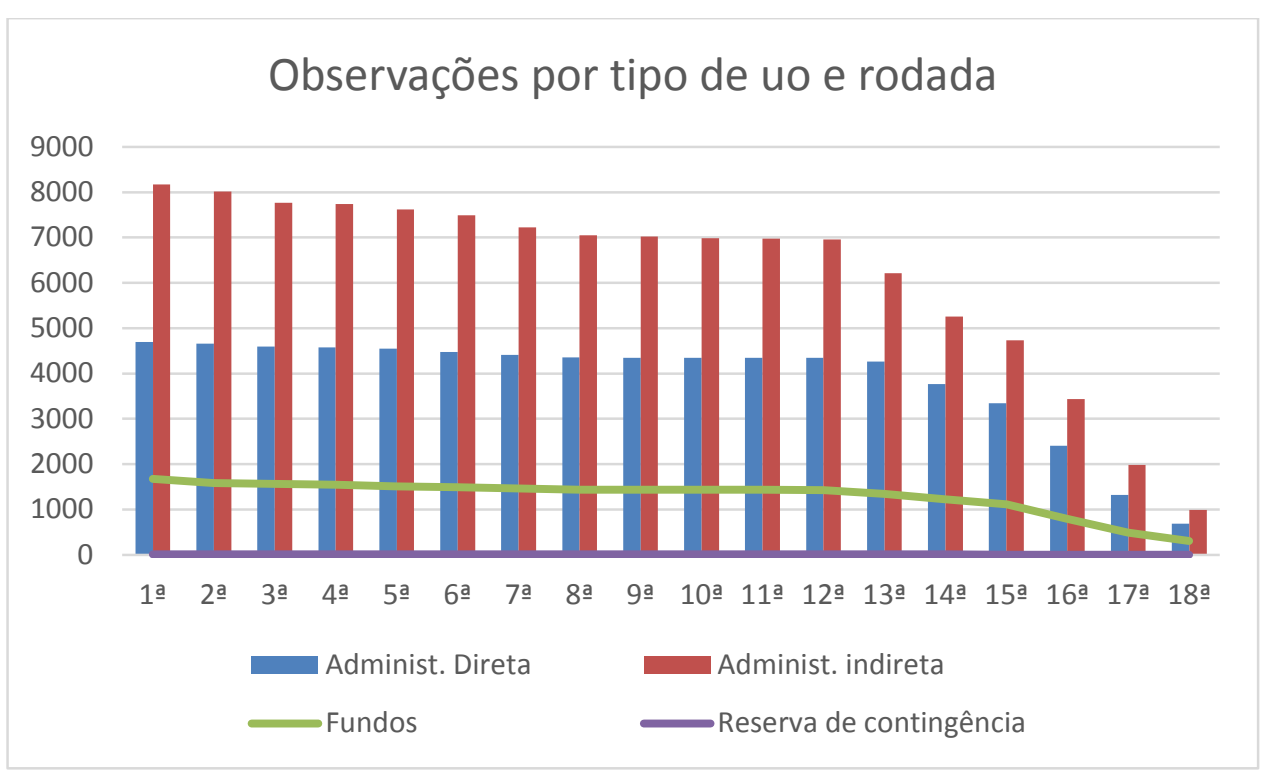

Fonte: Elaboração própria a partir do Stata 12

A Hipótese 4 tinha como pressuposto a expectativa de que as variabilidades seguiriam no sentido direto à flexibilidade das instituições, dado pela natureza jurídica das relações: administração indireta > administração direta> fundos contábeis. A partir dos dados obtidos, contudo, as entidades da Administração indireta são aquelas com maior variabilidade percentual, seguidas dos fundos contábeis e por último da Administração direta. Assim, a relação foi administração indireta > fundos contábeis > administração direta.

Para permitir melhor visualização da variabilidade das variações, foram gerados gráficos twoways sem e com stn2. 


\section{Figura 14 - observações por etapa e unidade orçamentária, sem e com stn2}
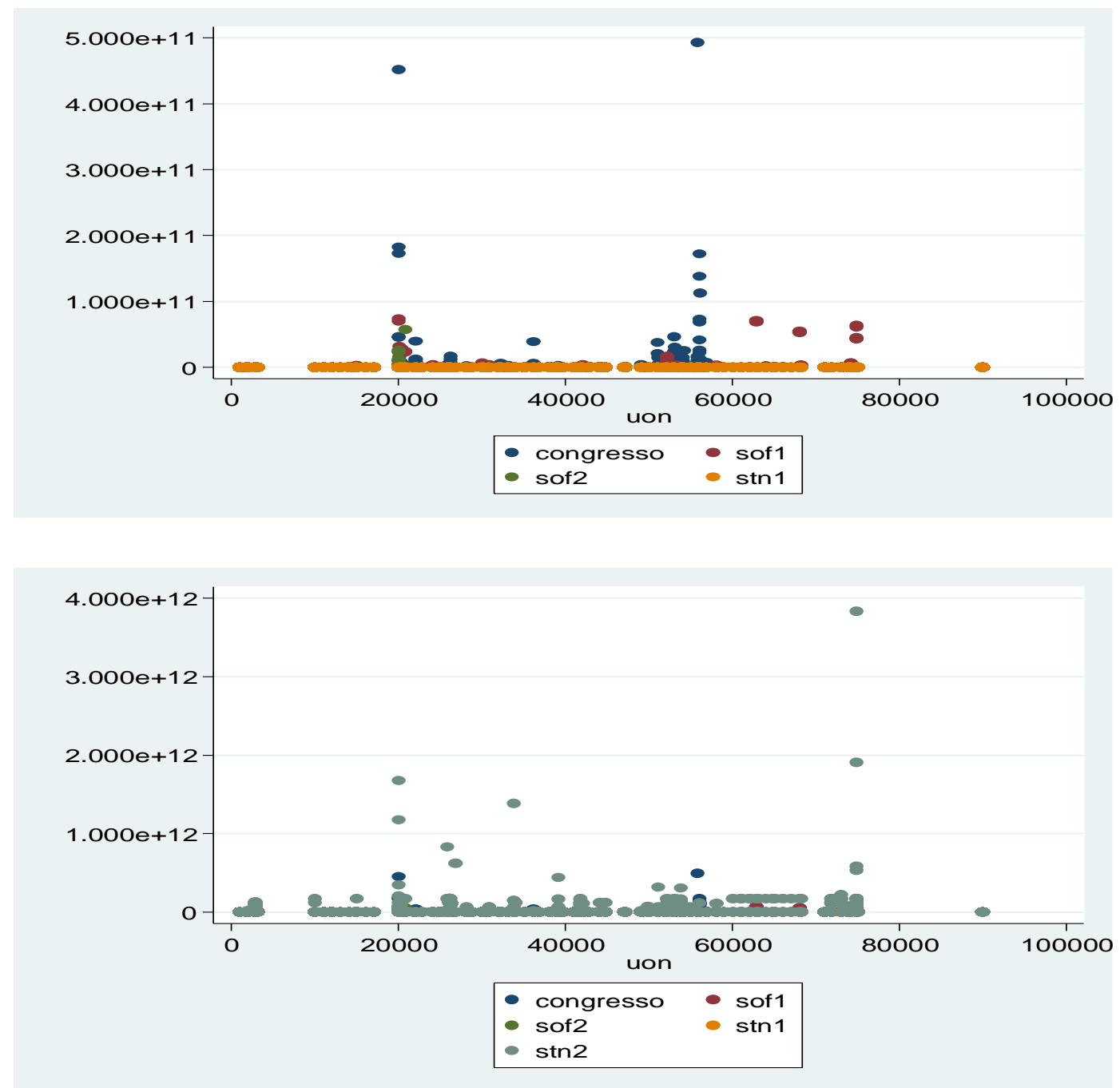

Fonte: Elaboração própria a partir de dados do Stata 12.

O momento stn2 apresenta observações com graus de variabilidade bem superiores às etapas anteriores, de forma que, quando visto em conjunto, encobre as variabilidades nas outras etapas. As observações destoantes concentraram-se no momento stn2, indicando que o maior grau de reformulação das agendas previstas e dos acordos realizados ocorre nessa fase. Em seguida, o Congresso aparece de forma destacada, o que confirma a percepção de que diversos acordos com vários atores envolvidos estão sendo desenhados nessa etapa. 
Cabe ao Congresso dispor sobre todas as matérias de competência da União, o que justifica as variabilidades entre os exercícios. Além disso, o processo legislativo é amplamente documentado e aberto, com exposição das justificações e responsabilidades pelas mudanças. Depois, as etapas sofl, sof2 e $\operatorname{stn} 1$ apresentam tendência decrescente de variação nessa ordem. Os gráficos a seguir demonstram os outliers conforme destacado a partir da visão geral, envolvendo todas as rodadas dos clusters. Após a $12^{\mathrm{a}}$ rodada a tendência de variabilidade segue na mesma sequência, porém em escala bem mais reduzida.

Figura 15 - observações por etapa e unidade orçamentária, após a $12^{\mathrm{a}}$ rodada, sem e com stn2
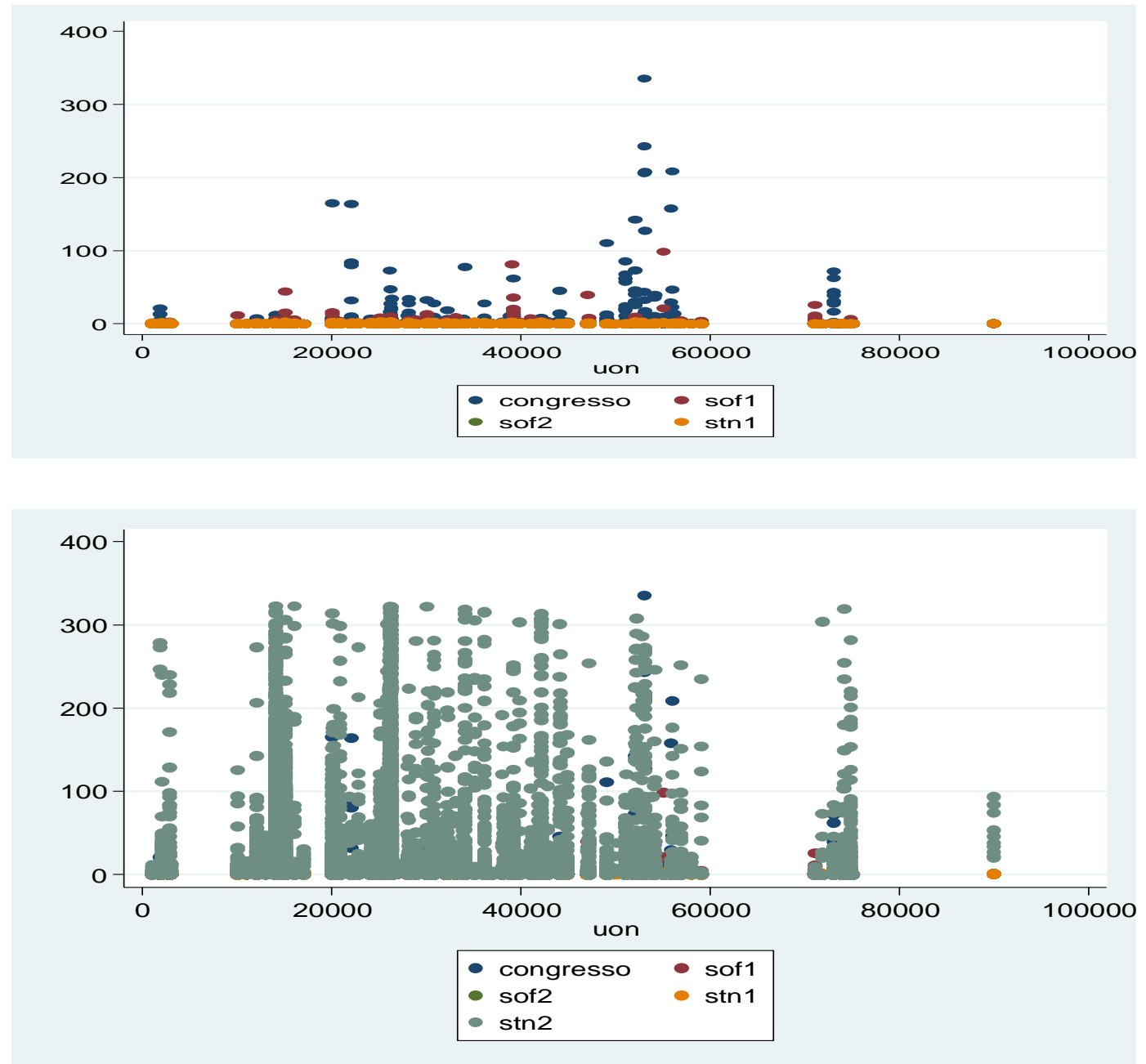

Fonte: Elaboração própria a partir de dados do Stata 12. 
As variabilidades identificadas nas etapas mencionadas se concentraram em determinadas unidades orçamentárias. A Presidência da República (20000) concentra diversas secretarias especiais, inclusive as transitórias, que, ao longo do tempo, transformaram-se em ministérios, e órgãos que, notadamente, recebem maior emendamento, pelo Congresso Nacional, como Turismo (53000), Integração Nacional (54000) e Cidades (56000)

Os gráficos de etapa por tipo reforçam a preponderância da volatilidade verificada em $\operatorname{stn} 2$, apontando uma aparente situação conflituosa nas decisões sobre o pagamento dos restos a pagar. As maiores diferenças do padrão homogêneo foram verificadas nos gastos que envolvem todos os grupos de despesas, deixando transparecer a mudança de agenda na relação entre pagamentos do exercício e de exercícios anteriores nos gastos de pessoal e serviços da dívida, itens não incluídos nos tipos anteriores.

\section{Figura 16 - observações por etapa e tipo sem e com stn2}

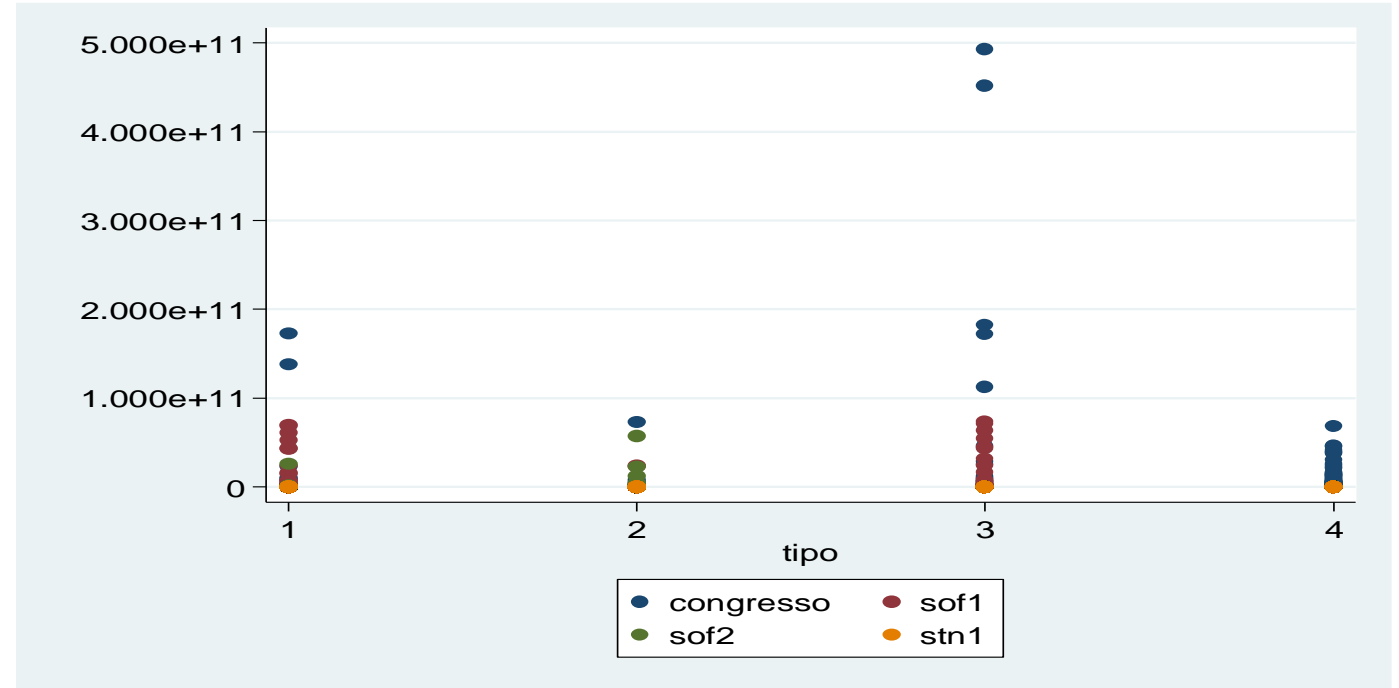




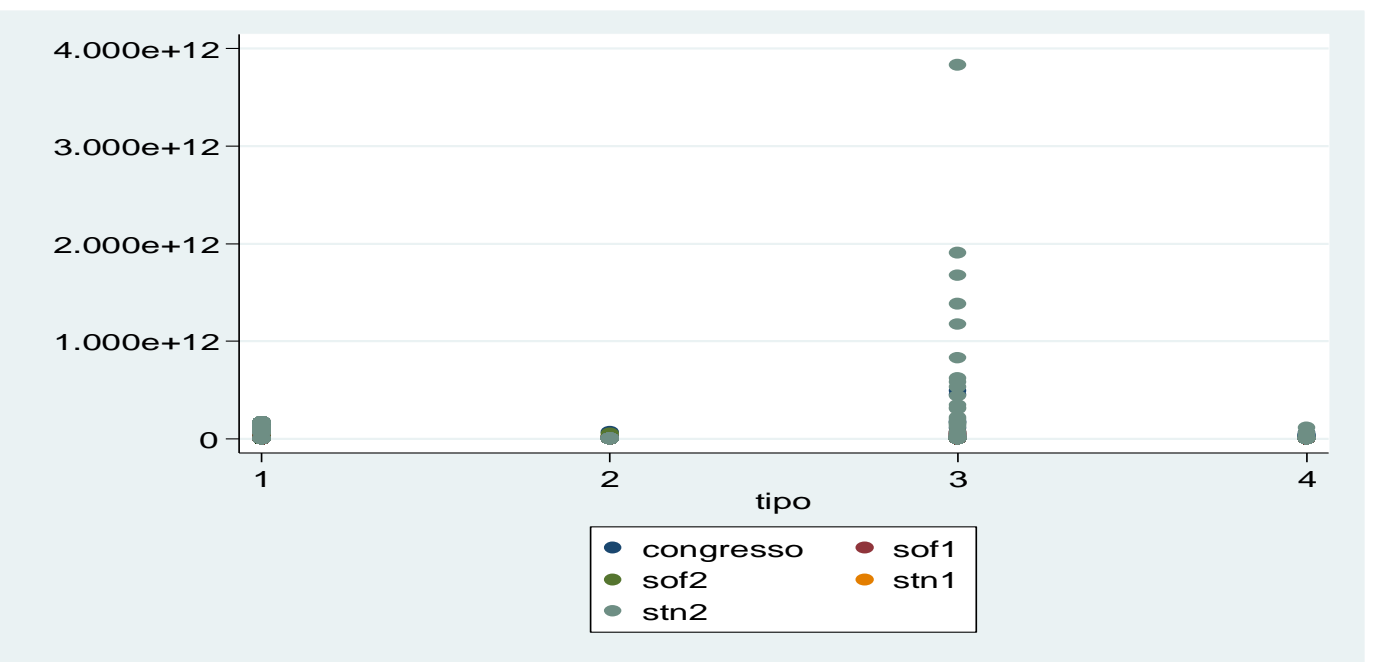

Fonte: Elaboração própria a partir de dados do Stata 12.

Dessa forma, os achados indicam de forma diferenciada à hipótese 4, que considerava que as variabilidades iriam se reduzindo ao longo do processo orçamentário, em uma relação na qual: congresso $>\operatorname{sof} 1>\operatorname{sof} 2>\operatorname{stn} 1>\operatorname{stn} 2$; enquanto a relação encontrada aponta a seguinte relação de variabilidade entre as etapas: stn $2>$ congresso $>$ sof $1>\operatorname{sof} 2>\operatorname{stn} 1$.

Essa relação vai ao encontro da indicação de Giacomoni (2010), que considera a importância do Congresso Nacional de participar também da elaboração do cronograma de desembolso financeiro. Os resultados apontam a necessidade de melhor conhecimento e descrição dos fatos que envolvem a geração e pagamento dos restos a pagar, pois, aparentemente, a consolidação e a decisão do efetivo cumprimento de acordos ocorrem, nesse momento, considerando-se todos os critérios de gasto do governo federal. 


\section{Figura 17 - observações por etapa e ano sem e com stn2}
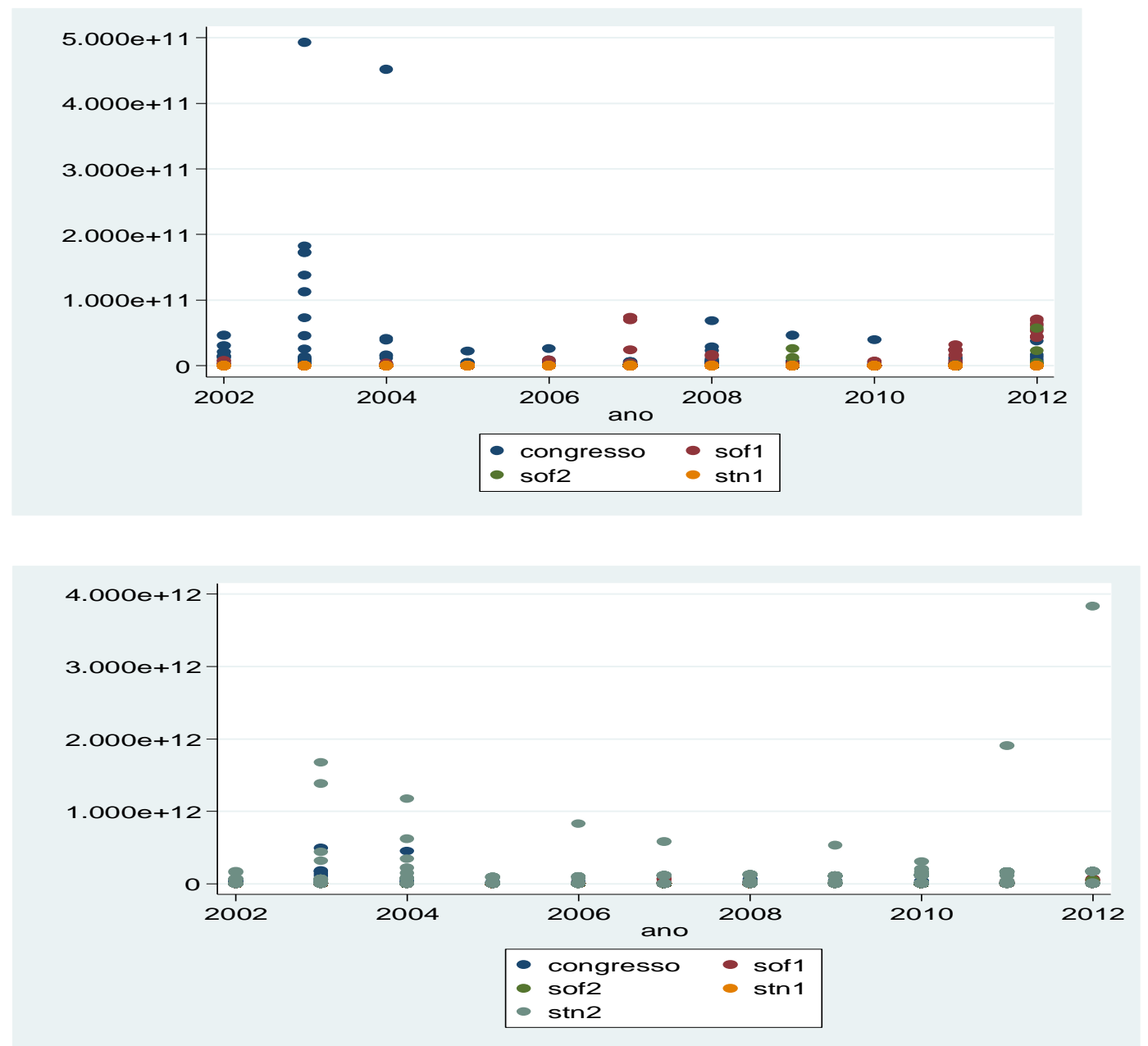

Fonte: Elaboração própria a partir de dados do Stata 12

Quando feita a comparação das variações a partir da combinação de etapa e ano, há a confirmação de que a etapa stn2 é aquela de maior volatilidade; porém destaca-se as diferenças no momento congresso principalmente no ano de 2003, o primeiro do governo Lula, situação que é ajustada no ano anterior a sua vigência, ou seja, os acordos realizados em 2002 na elaboração do PLOA pelo Congresso Nacional se refletem no exercício de 2003. 
4.2.5 Resultados da geração dos clusters

A Tabela 14 apresenta breve resumo da verificação das hipóteses apresentadas e as constatações a partir da análise de clusters.

Tabela 14 - verificação das hipóteses

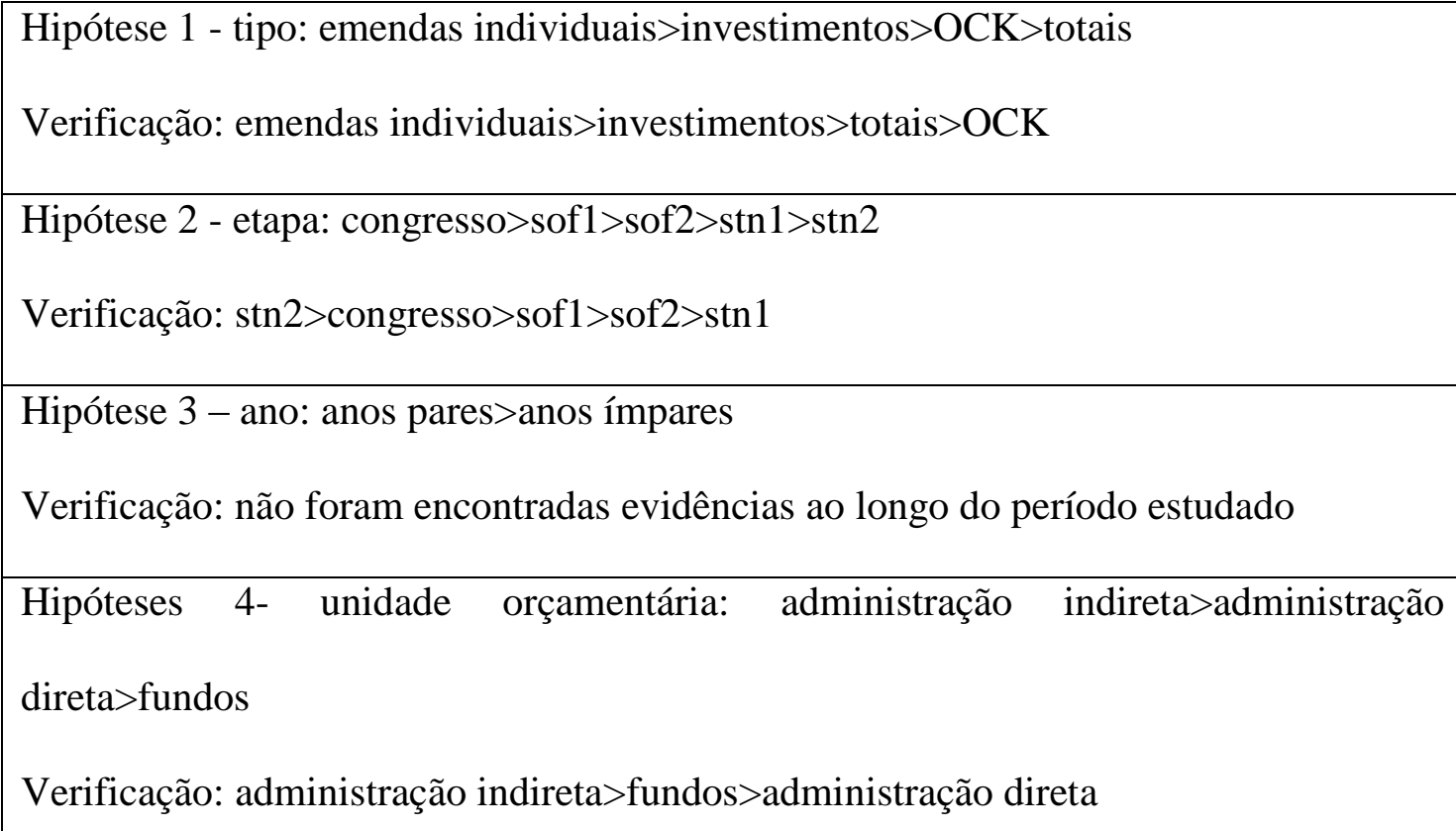

Fonte: Elaboração própria a partir dos resultados encontrados

A verificação das hipóteses formuladas pode ajudar a construir uma base para futuramente definir uma lei geral empírica do orçamento (JONES; BAUMGARTNER; BREUNIG, 2009). Nesse propósito, alguns indicativos podem ser sugeridos a partir das constatações em suas verificações.

Os grupos de despesas não apresentam comportamento idêntico, sendo que os referentes a emendas parlamentares e investimentos sofrem maiores interferências em suas execuções, o que aparentemente está alinhado com achados que apontam o uso de despesas referentes a tais gastos na gestão da governança (FIGUEIREDO; LIMONGI, 2008, PEREIRA; MUELLER, 2002). 
Entre as etapas, destaca-se o comportamento volátil durante o pagamento dos restos a pagar, sendo que as etapas anteriores apresentaram uma previsibilidade quando tratados seus comportamentos em relação as etapas anteriores e posteriores. A necessidade de uma maior participação dos atores envolvidos na elaboração do orçamento (Poder Legislativo) para definição da programação financeira (GIACOMONI, 2010) demonstra-se como fator, talvez, de ajuste em relação à programação inicialmente aprovada. Essa percepção quando avaliada sob a perspectiva da relação entre os atores envolvidos, e particularmente em consideração à teoria do Principal-Agente indica uma dominação do Poder Executivo no processo (FORRESTER, 2002).

A falta de evidência ou fatos que comprovassem a existência de PBC é uma verificação que transparece de forma contrária a literatura que identifica a sua existência (SHI; SVENSSON, 2002) e também, como característica de países em desenvolvimento (STREB; LEMA; TORRENS, 2003). Assim, pode-se sugerir que o orçamento não tem sido um instrumento patente de gestão dos pleitos eleitorais, pelo menos, o seu custo é insignificante frente aos gastos analisados em agregados. Talvez os custos para gestão da governança, incluindo interesses eleitorais seja baixo (PEREIRA; MUELLER, 2002).

O crescimento da Administração indireta, a partir da edição do Decreto-Lei n⿳⺈ 200, de 1967, dotou a Administração Pública de entidades cuja maior flexibilidade pode ser confirmada ou até mesmo incorrer em uma maior variabilidade orçamentária. 


\section{PADRÕES DE VARIABILIDADE}

\section{1 cluster average}

Para a identificação dos padrões de comportamento orçamentário, quanto à variabilidade orçamentária, entre os tipos de despesas e as etapas do processo orçamentário, decidiu-se a geração a partir de um tipo de cluster que fosse representativo e apropriado ao contexto orçamentário e as observações consideradas nesse estudo. A partir dos resultados dos clusters utilizados na fase anterior, que tratou da descrição dos dados e da verificação de algumas hipóteses, a pesquisa verificou critérios que apontam para o tipo de cluster mais desejável ou indicado para verificação das variabilidades orçamentárias.

\section{Figura 18 - exclusões por cluster e rodada}

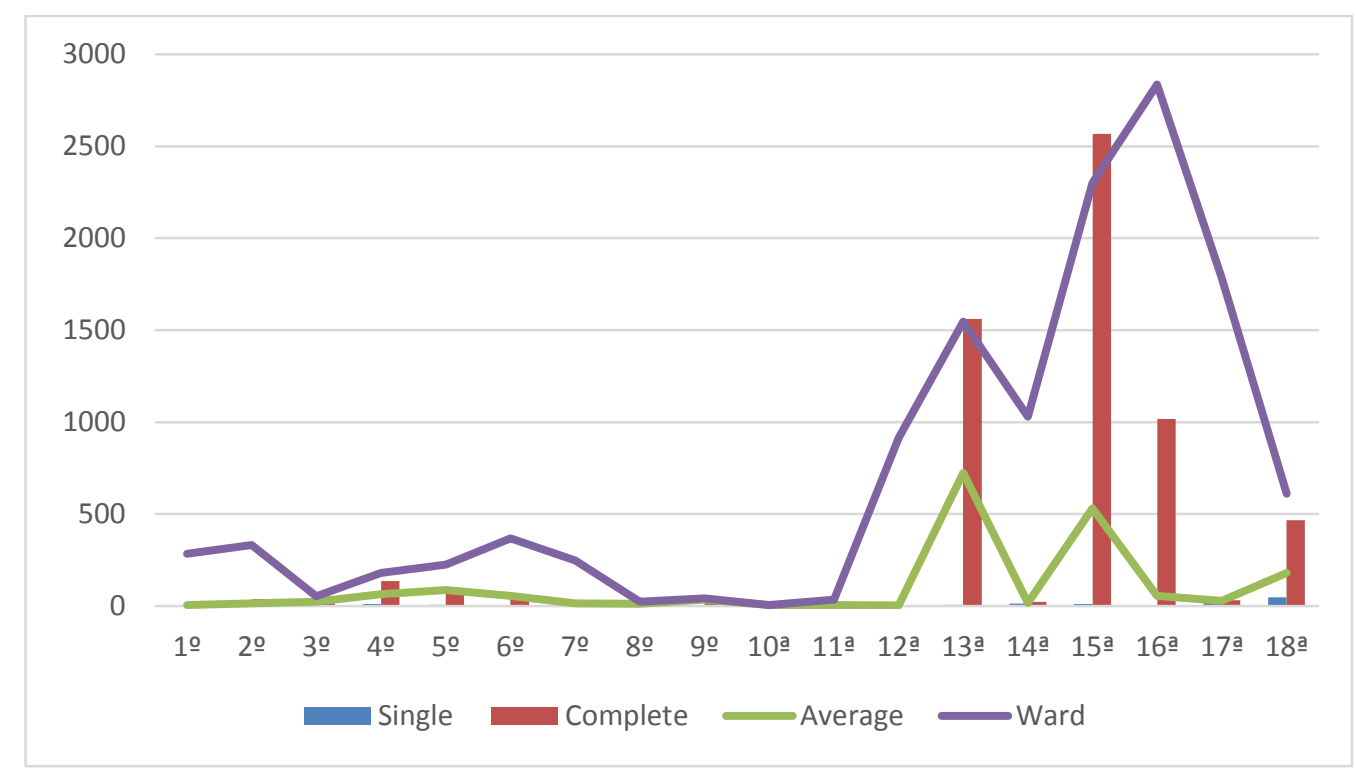

Fonte: Elaboração própria a partir de dados do Stata 12.

Durante a etapa realizada para a descrição dos dados, na qual foram utilizados os clusters single, complete, average e Ward conjuntamente com as exclusões de outliers a 
cada rodada, os clusters apresentaram comportamento diferenciado. Comparando o desempenho dos clusters, o Ward foi aquele que apresentou os maiores números de exclusão por rodada, cabendo ao single a posição daquele que menos observações excluiu nesses mesmos períodos. Dessa forma, o complete e o average apresentaram comportamentos intermediários.

Resumindo os tipos de clusters complete e average (EVERITT; LANDAU; LEESE, 2011), foi elencado entre as suas características, que o complete apresenta a tendência a formar clusters compactos com diâmetros equivalentes, sem levar em consideração as estruturas dos dados. Enquanto isso, o average tende a clusters com pequenas variações e com divisões relativamente robustos, assim como leva em consideração a estrutura dos dados.

Dentre as características citadas, foi considerado mais adequado para verificação de padrões de variabilidades orçamentárias em informações segmentadas o average. A tendência a evitar divisões insignificantes foi um ponto a mais a se considerar em favor dessa decisão, devido a tendência de juntar clusters com pequenas variações.

Para a descrição dos padrões de variabilidade orçamentária, decidiu-se, então, utilizar o cluster average, com sua formação após a $12^{\mathrm{a}}$ rodada, haja vista este ponto ser o divisor no detalhamento das rodadas utilizadas na etapa anterior desse estudo, como aquele momento no qual as exclusões passaram a ser mais significativas. Compreende-se que até este momento provavelmente estava ocorrendo apenas a retirada dos outliers, cuja ocorrência tem explicação em grande parte dos casos verificados devido a alterações na classificação ou mudança de vinculação institucional. Ademais, a equiparação da posição relativa média dos pontos, em lugar da sua otimização, parece mais coerente com a teoria incrementalista subjacente à abordagem orçamentária (PADGETT, 1980; BARCELOS, 2008). 
Para identificação dos padrões, para posterior descrição, foi gerada uma árvore do cluster average, com a configuração da $12^{\mathrm{a}}$ rodada, no número de 100 grupos, o máximo permitido pelo programa. O resultado apresentado foi uma distribuição na qual quase $75 \%$ das observações concentravam-se em três padrões majoritários. Desse modo, a distribuição das observações seguiu os seguintes padrões.

\section{Tabela 15 - Distribuição dos padrões}

\begin{tabular}{r|r|r|r}
\hline \multicolumn{1}{c|}{ Padrões } & Quantidade de observações & \multicolumn{1}{c|}{$\%$} & \% acumulado \\
\hline 3 & 8.367 & 57,51 & 57,51 \\
\hline 1 & 1.401 & 9,63 & 67,14 \\
\hline 8 & 773 & 5,31 & 72,45 \\
\hline outros & 4.009 & 27,55 & 100,00 \\
\hline total & $\mathbf{1 4 . 5 5 0}$ & $\mathbf{1 0 0 , 0 0}$ & \\
\hline
\end{tabular}

Fonte: Elaboração própria

Segue a trajetória das distribuições por tipos.

\section{Tabela 16 - Trajetória das distribuições}

\begin{tabular}{|c|c|c|c|c|c|c|c|c|c|c|c|c|c|c|c|}
\hline & $\mathbf{A}$ & & & $\begin{array}{c}\text { B } \\
\text { (r12) }\end{array}$ & & & $\mathbf{C}$ & & & & $\% \mathrm{C} / \mathrm{A}$ & & D & & \\
\hline tipo & $\mathbf{N}$ & $\%$ & $\% c$. & $\mathbf{N}$ & $\%$ & $\% c$. & tipo & $\mathbf{N}$ & $\%$ & $\% c$. & $\%$ & tipo & $\mathbf{N}$ & $\%$ & Cum. \\
\hline totais & 4.580 & 31 & 31 & 4.243 & 33 & 33 & totais & 4.213 & 40 & 40 & 92 & ock & 1.666 & 42 & 42 \\
\hline ock & 4.361 & 30 & 61 & 4.065 & 32 & 65 & investimentos & 2.833 & 27 & 67 & 71 & investimentos & 1.150 & 29 & 70 \\
\hline investimentos & 3.983 & 27 & 89 & 3.592 & 28 & 93 & ock & 2.695 & 26 & 92 & 62 & emendas & 826 & 21 & 91 \\
\hline emendas & 1.626 & 11 & 100 & 839 & 7 & 100 & emendas & 800 & 8 & 100 & 49 & totais & 367 & 9 & 100 \\
\hline Total & 14.550 & 100 & & 12.739 & 100 & & Total & 10.541 & 100 & & & Total & 4.009 & 100 & \\
\hline
\end{tabular}

Fonte: Elaboração própria

\subsection{Padrão 3}

Para melhor visualização e compreensão dos padrões, haja vista que os exercícios não apresentam no período abordado interferência que possa caracterizar padrões diferenciados, está exposta a seguir a distribuição considerando as etapas por tipo de 
despesa. Com relação ao comportamento verificado durante a apreciação legislativa, os grupos possuem padrão idêntico, à exceção daquele envolvendo os gastos totais. A diferença sof1, que retrata a reprogramação após a aprovação da LOA, caracteriza a ocorrência de ajustes ao longo do exercício, sendo as emendas as que sofrem uma menor readequação.

\section{Figura 19 - Padrão 3 por tipo e etapa}

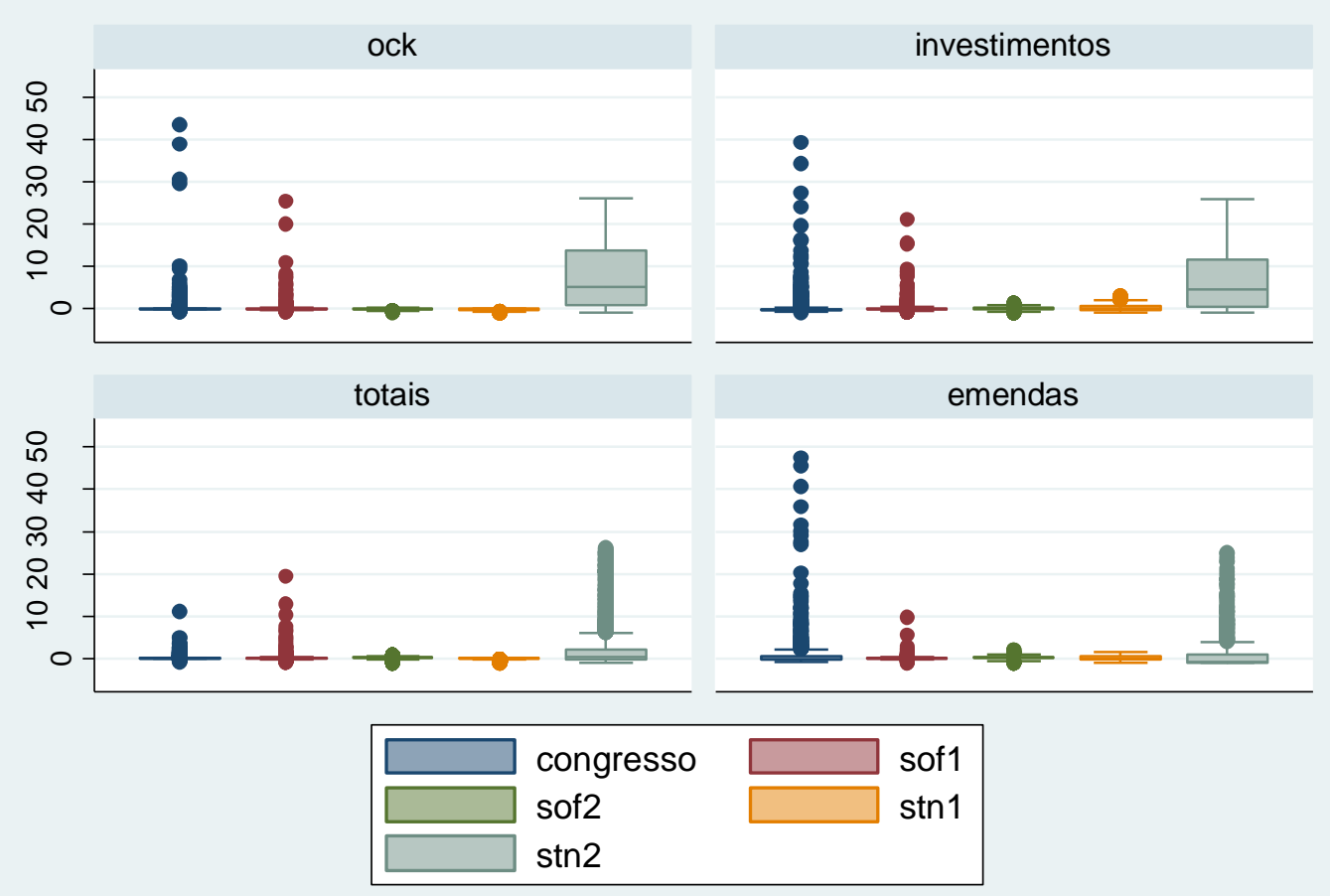

Graphs by tipo

Fonte: Elaboração própria a partir do Stata 12.

O padrão 3 representou $66 \%$ das observações totais do cluster average na $12^{\mathrm{a}}$ rodada e $58 \%$ de todas as observações. As variabilidades verificadas no momento Congresso podem demonstram que as preferências dos parlamentares e critérios de decisão estão mudando de forma dinâmica, representando tentativa de encontrar pontos de maior impacto e visibilidade perante os eleitores. Não há fidelidade recorrente com determinado setor, 
As reprogramações são uma indicação clara observada após a aprovação da LOA, e pode significar os ajustes daqueles que perderam durante a apreciação legislativa ou mesmo não tiveram todas as suas demandas atendidas, deixando claro que parte do orçamento após sua aprovação passa por essa reprogramação. A programação orçamentária, que trata do estabelecimento de limites de movimentação e empenho, também chamado de contingenciamento, e a financeira do exercício corrente não apresentaram grandes variações, o que demonstra que essas etapas tem um comportamento bem previsível.

O grande ponto conflituoso e altamente volátil são os pagamentos dos restos a pagar, caracterizando como uma arena na qual parece ocorrer conflito de interesse para assegurar o cumprimento final dos acordos tempestivamente. As unidades orçamentárias com maior número de ocorrência no padrão 3 foram: EMBRAPA, MCTI, Universidade Federal do Paraná, MJ, MPF, FNS, MMA, e os três Comandos Militares. 


\section{Figura 20; padrão 3 por tipo, poder e etapa}

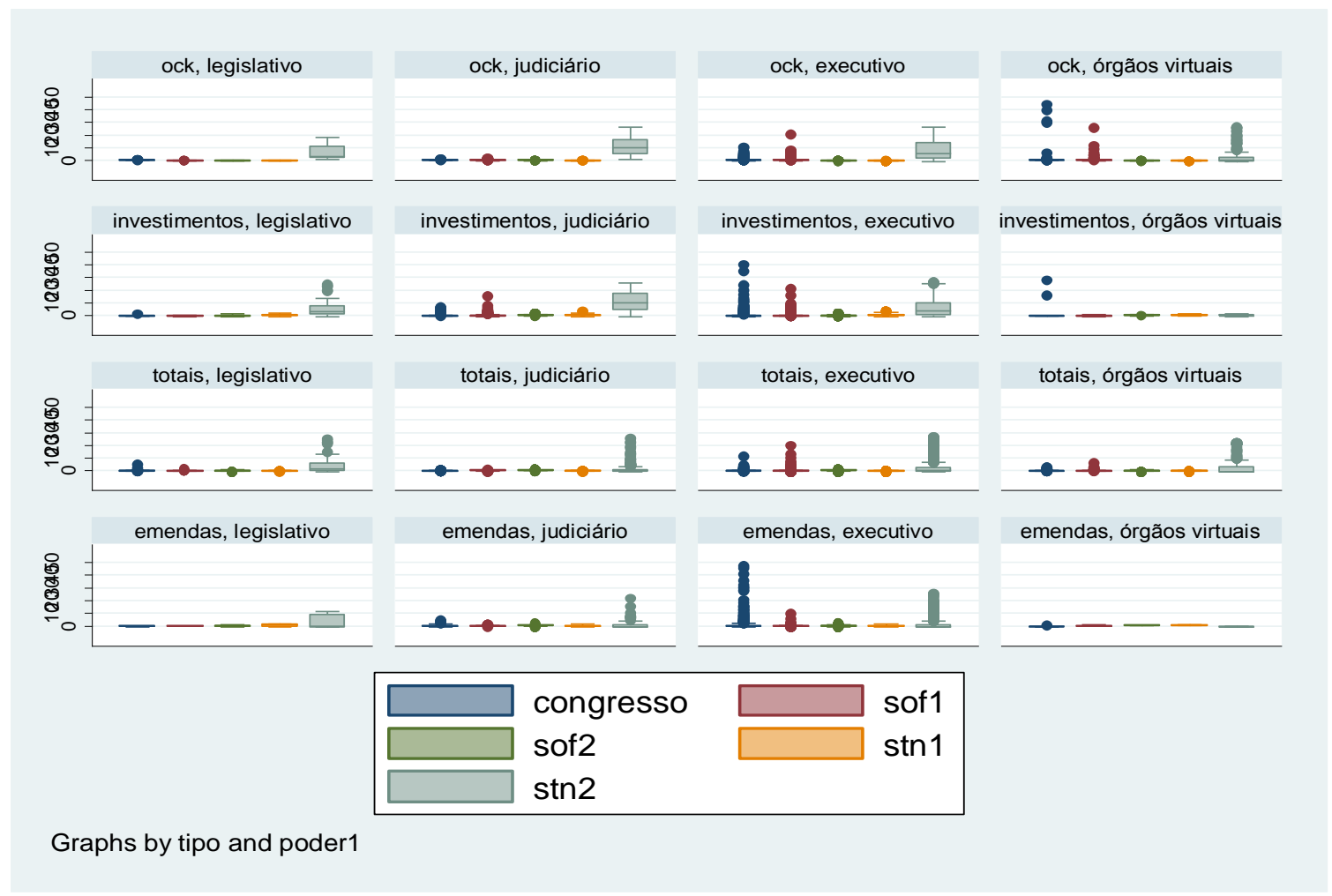

Fonte: Elaboração própria a partir de dados do Stata 12

O comportamento dos gastos correntes e com investimentos dos órgãos virtuais e investimentos e emendas parlamentares individuais, em relação às unidades orçamentárias do Executivo, segue padrão de uma etapa inicial de apreciação pelo Congresso Nacional, que apresenta maior variabilidade, seguida de variações menos intensas decorrentes de créditos adicionais. Há redução da instabilidade das agendas na execução e no pago, mas ela recrudesce com intensidade no pagamento dos restos a pagar.

Se as variabilidades orçamentárias demonstram incertezas, os momentos mais críticos na concretização dos acordos com sustentação no orçamento público federal ocorrem, nesse grupo, pela ordem, durante a apreciação legislativa, o pagamento dos restos a pagar e a reprogramação das agendas efetuada mediante créditos adicionais.

As emendas do Congresso em órgãos virtuais, referente a despesas financeiras e transferências vinculadas, são atribuídas às transferências para Estados e municípios, o 
que merece atenção em pesquisas subsequentes. Quanto à abordagem institucional por Poder, o Executivo sofre variações em todos os tipos e etapas. No Poder Judiciário, somente os gastos com investimentos apresentam variabilidades. No Poder Legislativo, não são verificadas variações significativas em comparação com os demais órgãos. Em todas as situações a gestão dos restos a pagar demonstra-se instável, e sujeita a diversas variabilidades.

\section{Figura 21: padrão 3 por etapa e ano}

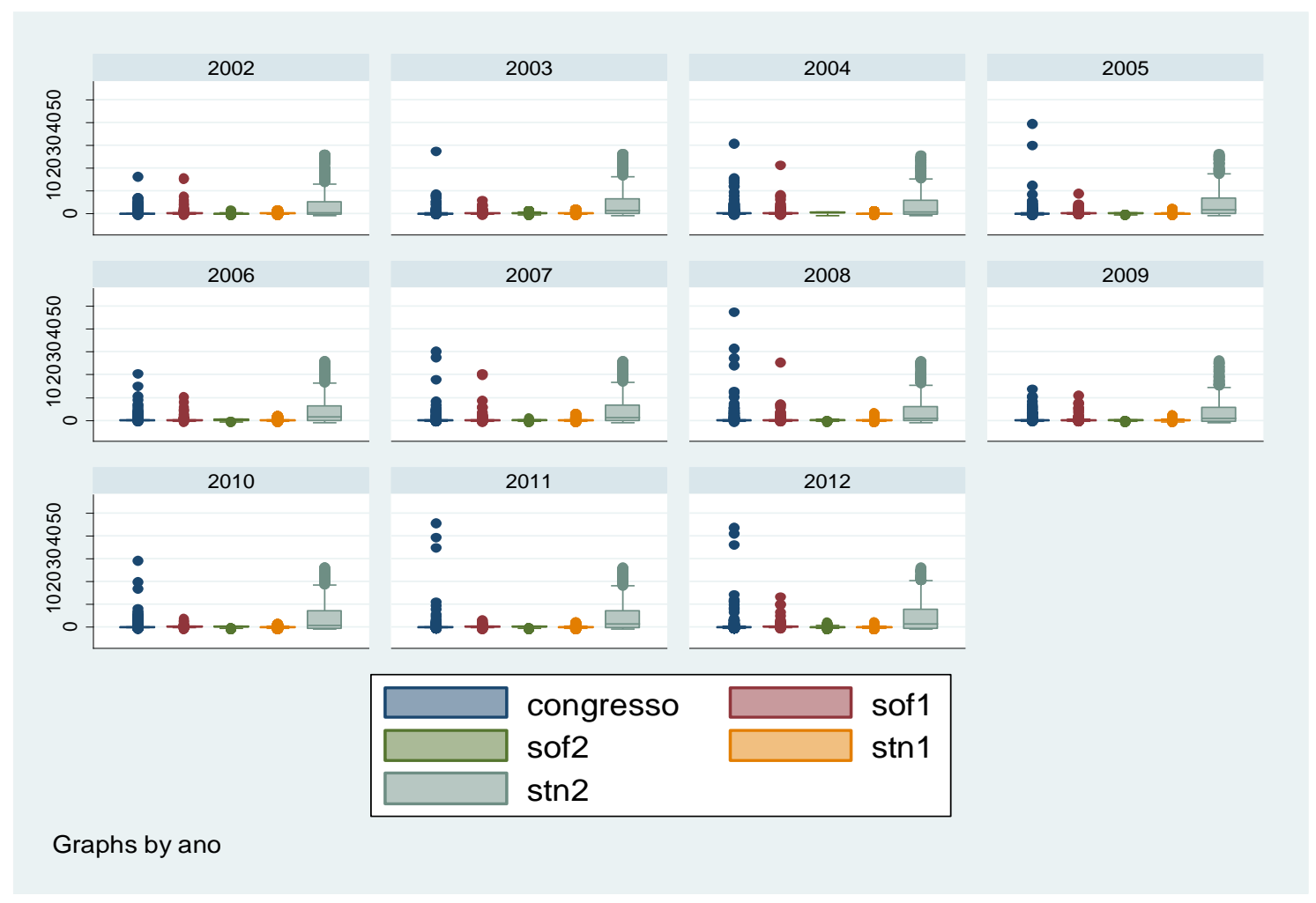

Fonte: Elaboração própria a partir de dados do Stata 12

As variações ao longo dos exercícios não demonstram aparentemente a existência de ciclos eleitorais ou mudança nos padrões entre as etapas do processo orçamentário. 


\subsection{Padrão 1}

O Padrão 1 representou 11,0 \% das observações, na Rodada 12, e 10\% de todas as observações. Os gráficos a seguir demonstram suas características. As variabilidades no padrão 1 são ligeiramente inferiores do que o padrão 3, e sofrem oscilações de agenda nos pagamentos dos restos a pagar. As principais unidades orçamentárias com maior número de observações nesse padrão são: DNPM e algumas unidades do Poder Judiciário integrantes principalmente da Justiça eleitoral.

\section{Figura 22: padrão 1 por tipo e etapa}

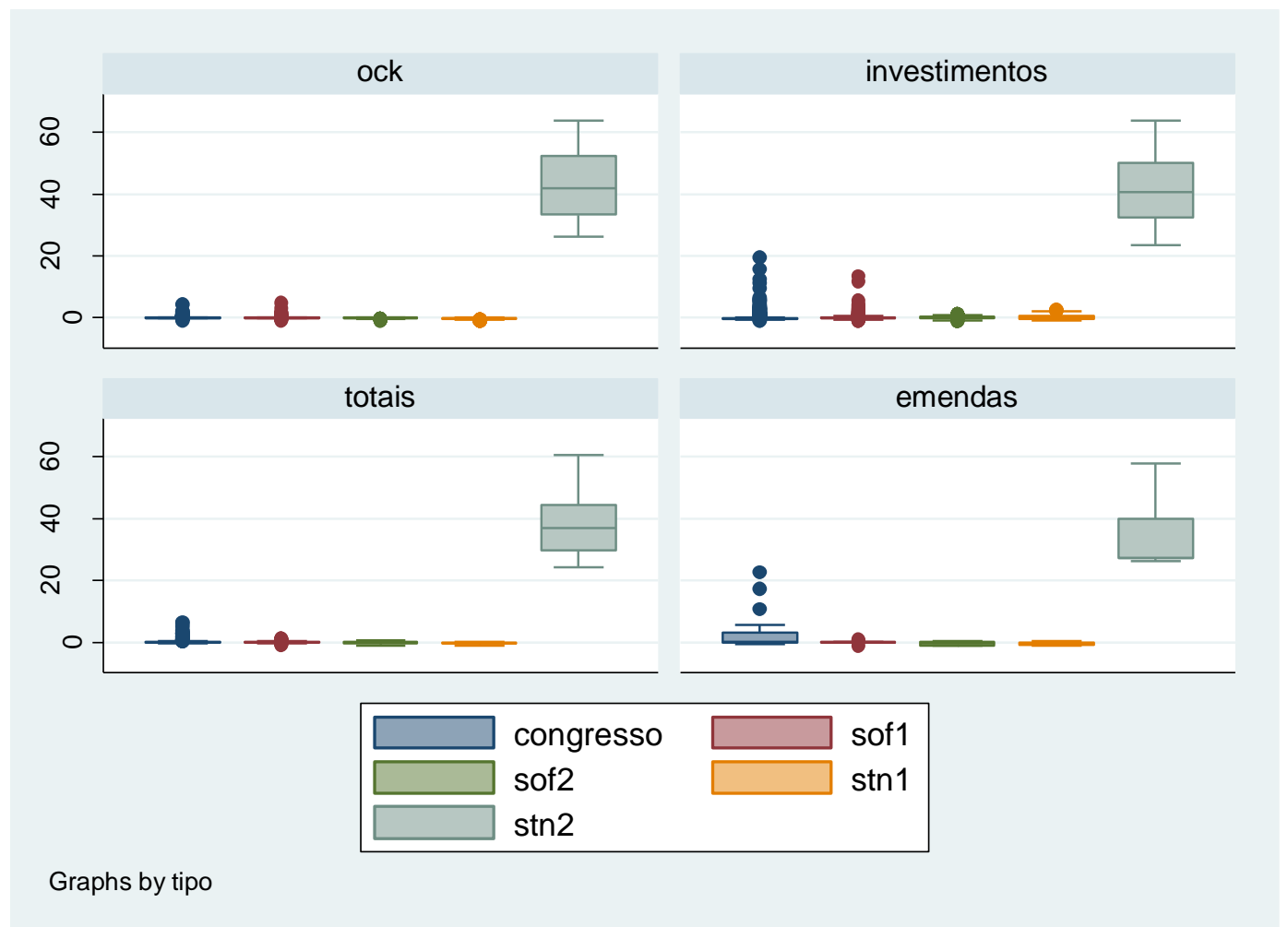

Fonte: Elaboração própria a partir do Stata 12.

As variabilidades nesse padrão são bem mais reduzidas, com algum destaque para os investimentos no Poder Executivo e no Poder Judiciário, bem como as emendas em unidades orçamentárias do Executivo. Como a interferência legislativa é pequena, as reprogramações são de menores monta, e praticamente só no grupo de investimentos. As 
programações objeto de emendas parlamentares individuais apresentam poucas reprogramações.

Figura 23: padrão 1 por etapa e tipos de uo e despesa

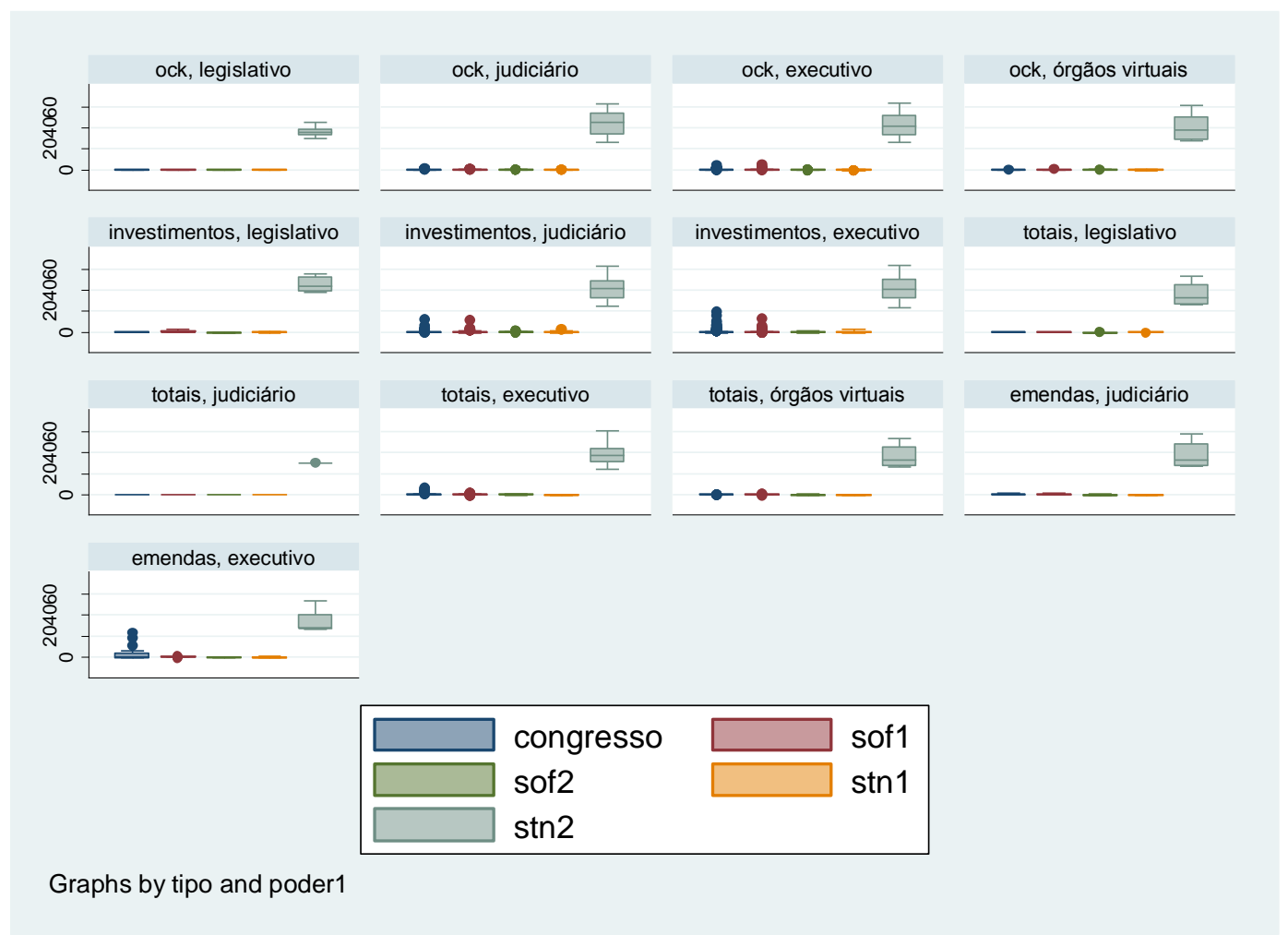

Fonte: Elaboração própria a partir do Stata 12.

A variabilidade entre os exercícios é um pouco menor do que no padrão, tendendo a sofrer menores alterações no processo orçamentário e a cada ano. Este padrão é relativamente próximo do padrão 3, o principal descrito anteriormente. Também não há evidência de interferência do ciclo eleitoral na caracterização do padrão. 


\section{Figura 24: padrão 1 por etapa e ano}

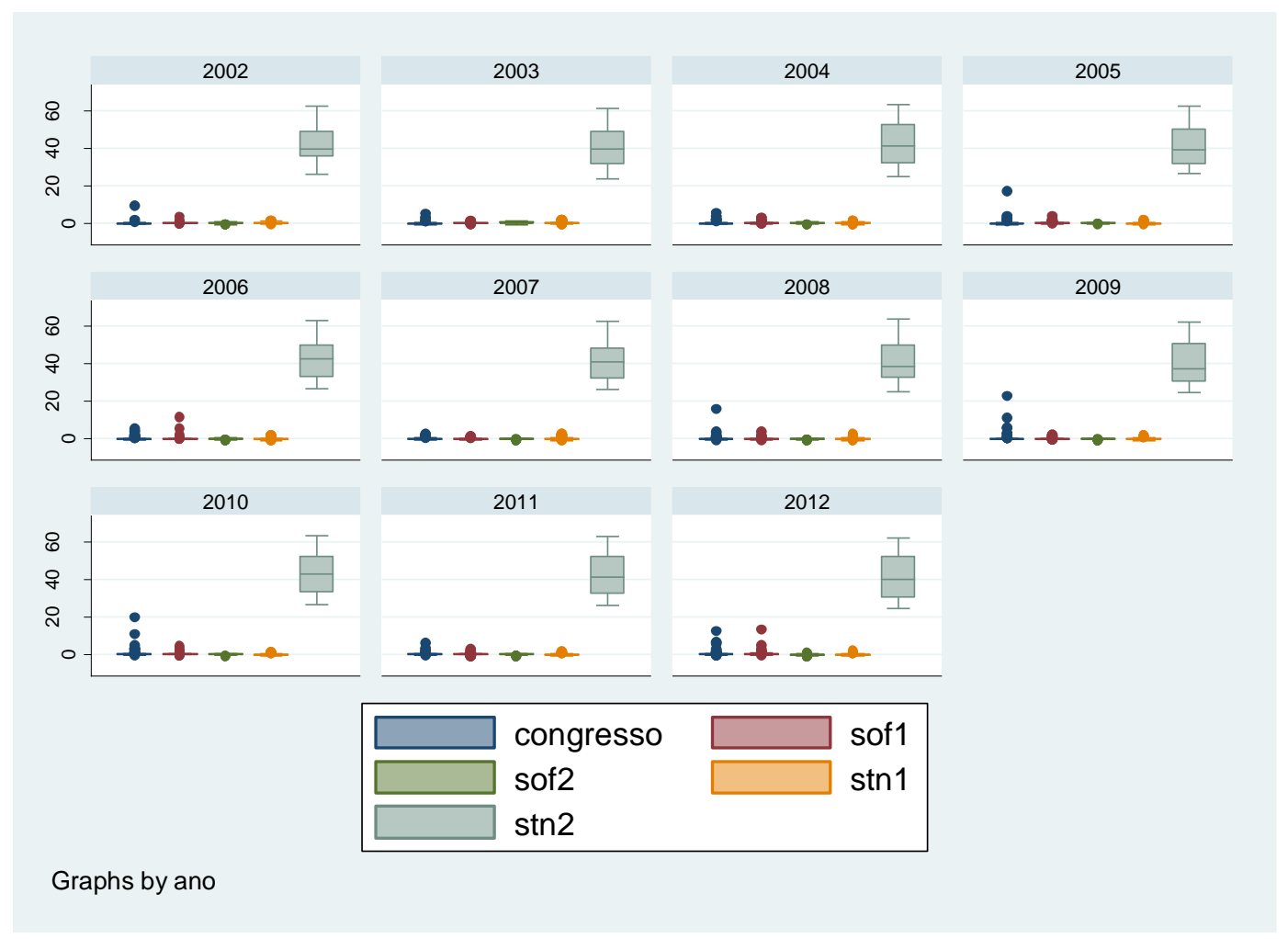

Fonte: Elaboração própria a partir do Stata 12.

\subsection{Padrão 8}

O padrão 8 corresponde a 6,0\% das observações relativas à Rodada 12 e 5\% do total de observações. No dendograma, sua medida de dissimilaridade é pouco superior à existente entre os Padrões 1 e 3. Nesse padrão as variações não estão associadas a percepção de ocorrência mais acentuada em determinado exercício, com exceção da clara dissonância dos restos a pagar pagos, cujo grau de mudança de agenda é ainda mais saliente do que nos padrões anteriores. Desse modo, o Padrão 8 apresenta variabilidade em nível aparente inferior e as principais unidades orçamentárias com maior número de ocorrência são as integrantes da estrutura da Justiça do Trabalho. 


\section{Figura 25:padrão 8 por tipo e etapa}

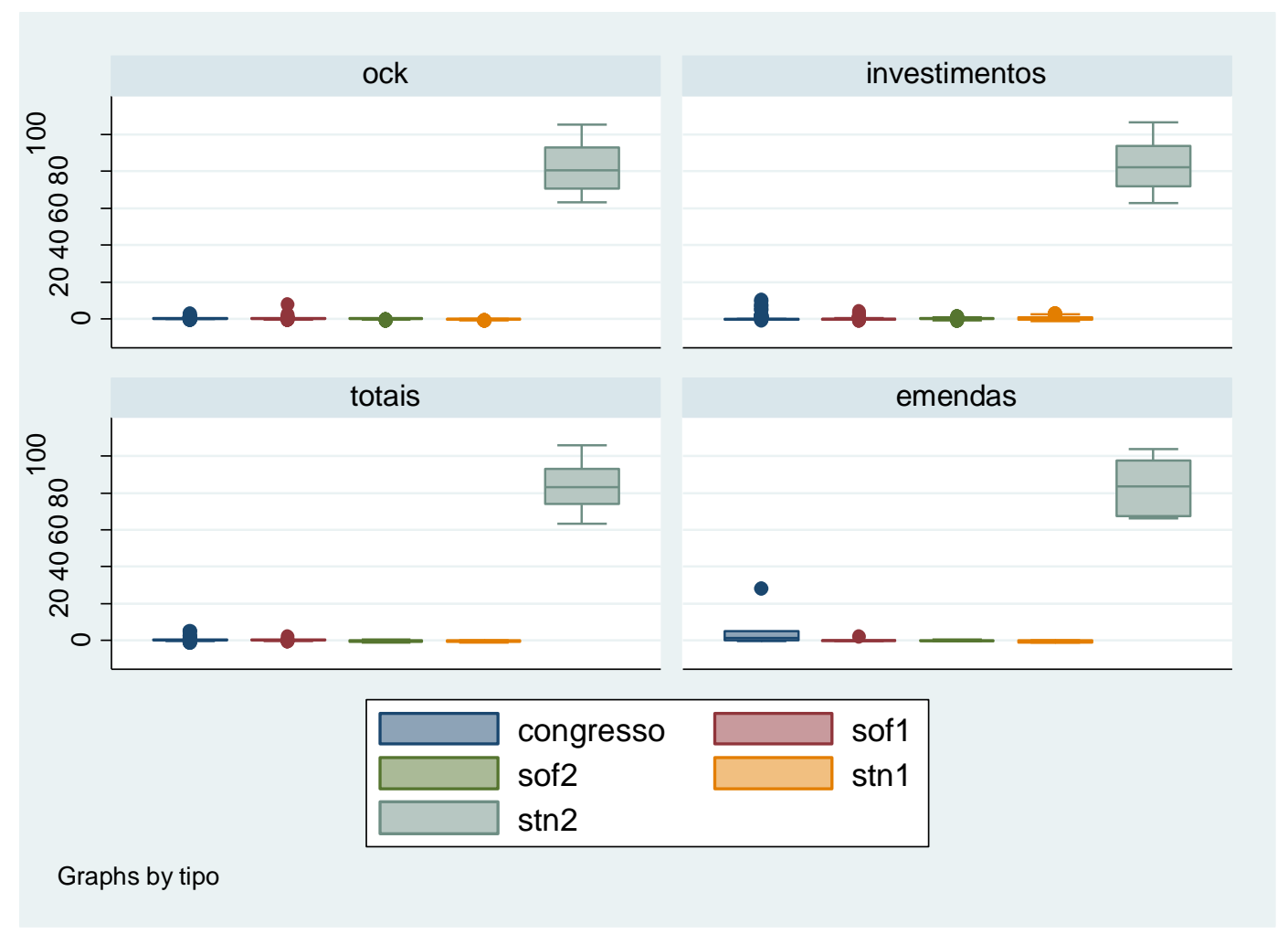

Fonte: Elaboração própria a partir do Stata 12

No Padrão 8, os gastos do executivo em ock tem uma maior preocupação com sua reprogramação. Os investimentos nesse padrão também são objeto de atenção durante o período de apreciação legislativa. Os comportamentos de determinado grupo de despesa, como por exemplo investimentos, não pode ser considerado como semelhante nos demais grupos estudados. Os padrões dos restos a pagar pagos é mais destoante que os anteriores analisados. Porém, aparentemente existem semelhanças, como a existência de reprogramação após variações verificadas durante a apreciação legislativa. 
Figura 26: padrão 8 por etapa, tipo de unidade orçamentária e despesa.

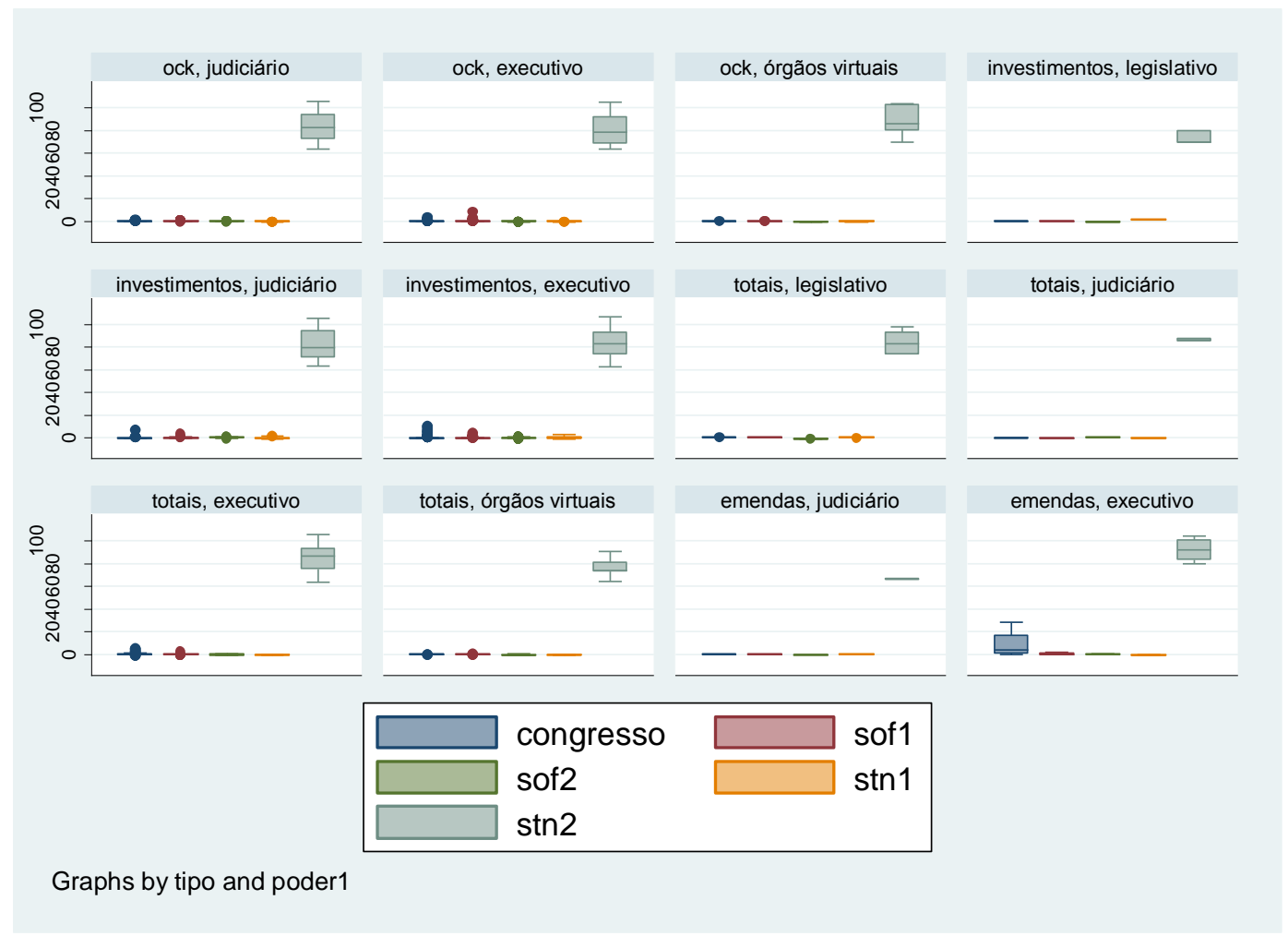

Fonte: Elaboração própria a partir do Stata 12.

A diferença de escala dos restos a pagar oblitera qualquer percepção de variação regular associada aos ciclos eleitorais.

\section{Figura 27: padrão 8 por etapa e ano}

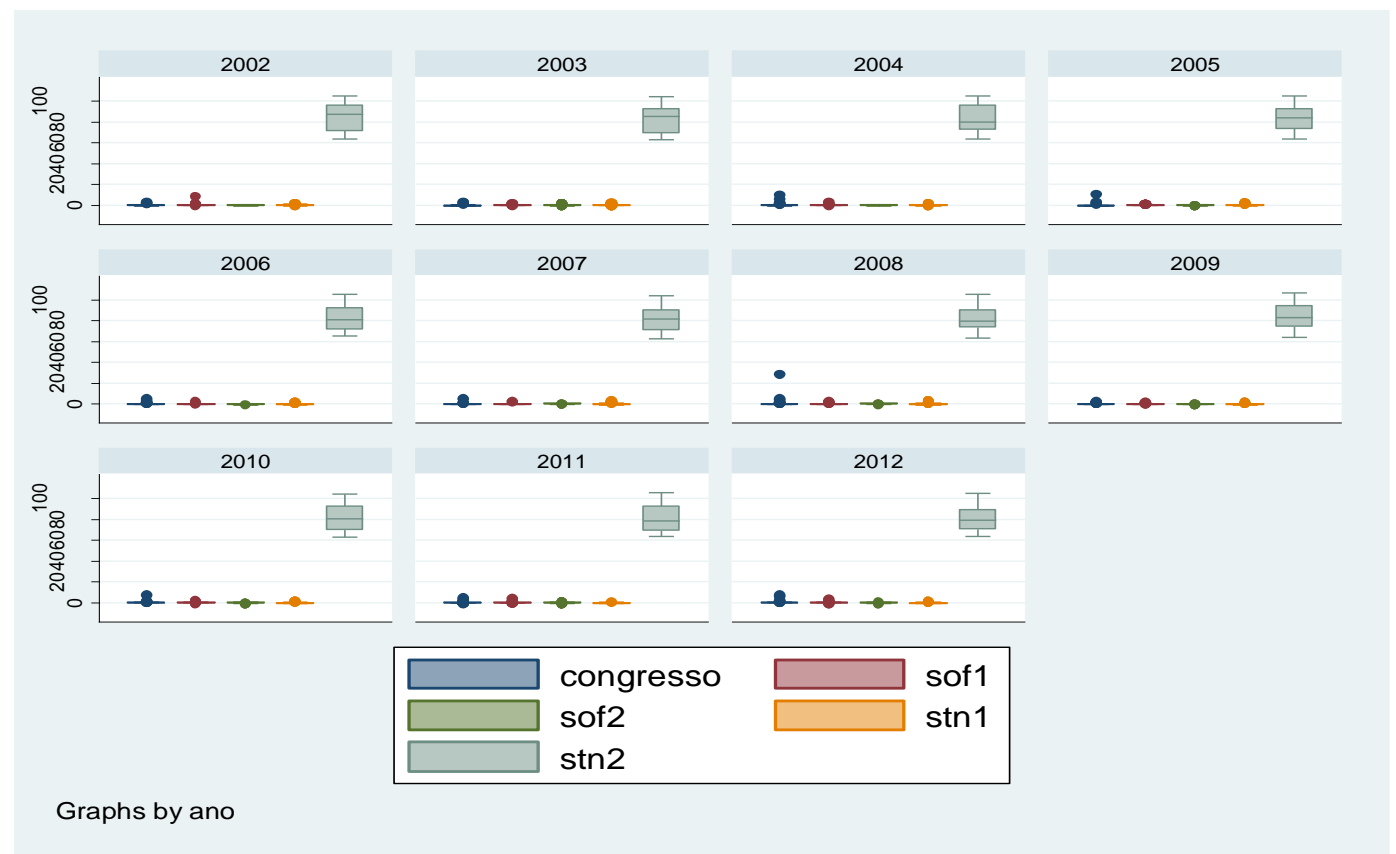




\section{CONCLUSÃO}

Esta pesquisa demonstrou que o orçamento é uma rica fonte de informação para melhor compreensão do processo político e demais situações que lhe dizem respeito. Dessa forma, as variabilidades orçamentárias representadas pelas variações percentuais tanto dos recursos destinados entre as unidades orçamentárias como nas diversas etapas desde a elaboração do PLOA, até o pagamento final da despesa executada e dos restos a pagar, podem revelar formas de comportamento dos atores políticos.

O estudo do orçamento público por meio da análise de cluster mostrou-se uma metodologia analítica promissora, pois sua aplicação permitiu identificar determinadas situações que confirmam a literatura e outras, que aparentemente apontam em outras direções, sugerindo novos campos de estudo. Dessa forma, suas possibilidades são inúmeras e em um assunto como o orçamento público, no qual as informações são de grande monta, diversificadas e segmentadas, a análise de cluster é uma ferramenta que não pode ser prescindida com vistas a um bom entendimento do processo orçamentário.

O orçamento público quantifica as decisões políticas (JONES; BAUMGARTNER; BREUNIG, 2009), e a descrição dos padrões permite compreender parte da gestão política do orçamento. O entendimento do que as informações revelam possibilitará compreender sua relação com outros campos do setor público, tal como a melhoria da governabilidade e a prevenção de riscos regulatórios.

A aplicação dos clusters aos dados orçamentários entre o período de 2002 a 2012, considerando suas etapas, instituições e grupos de despesas demonstrou, como se vê, que 
o orçamento praticamente segue um padrão hegemônico, o que permite inferir que a grande maioria das ações e instituições integrantes do orçamento seguem um padrão similar e previsível. Note-se que, do ponto de vista teórico, cabe a descrição do orçamento a partir de uma lei empírica ou modelo (JONES; BAUMGARTNER; BREUNIG, 2009; DAVIS; JONES; WILDAVSKY, 1966), considerando a existência de um padrão hegemônico.

Na descrição desse padrão hegemônico foi possível identificar subgrupos, apesar de as diferenças não serem tão expressivas, com padrões distintos entre os órgãos dos Poderes Executivo, Legislativo e Judiciário, nos quais as maiores oscilações ocorreram nas instituições que integram o Poder Executivo.

Dentre as percepções da descrição específica do padrão predominante, não foi possível identificar que o presidencialismo de coalizão implica em um tratamento diferenciado com relação às despesas decorrentes de emendas parlamentares individuais. A rigor o tratamento é semelhante ao de outras formas de apuração dos gastos públicos, podendo significar um custo inexpressivo a manutenção da base de apoio político por meio dessas emendas (PEREIRA; MUELLER, 2002). Porém, quando avaliado no grupo total sem exclusões, é verificada a caracterização do presidencialismo de coalizão por meio da maior variabilidade das emendas parlamentares.

Vale destacar que a partir da Lei de Diretrizes Orçamentárias para 2014, foi previsto um tratamento diferenciado tornando obrigatória a execução das emendas parlamentares individuais. Tal mecanismo apenas revela que o grau de reprogramação das escolhas públicas, efetuado pelo Executivo, no pagamento dos restos a pagar é um fator de desestabilização da previsibilidade orçamentária. 
A variabilidade verificada na etapa que envolve o pagamento dos restos a pagar constituiu-se em achado mais destacado desta pesquisa, demonstrando ser uma situação merecedora de maiores estudos com vistas a melhor descrição e entendimento das relações e decisões ocorridas neste momento, que aparentemente revelam uma revisão de todo o processo decisório. Assim, parece que esse momento constitui-se em uma arena política de definição da execução de políticas públicas, retirando o caráter preponderante das oscilações antes identificadas durante a apreciação legislativa (FIGUEIREDO; LIMONGI, 2008).

Nesse quesito, considerando as variabilidades orçamentárias como indicador demonstrativo do toma lá dá cá da política (LASWELL, 1936), e entendendo que as oscilações maiores podem ser decorrentes das instabilidades dos acordos com reflexo no orçamento; os anos mais recentes deste estudo, de 2009 até 2012, podem ser uma demonstração de que o orçamento tem sido um meio mais utilizado na gestão e constituição das coalizões de governo. Porém, é importante destacar a necessidade de uma melhor descrição do contexto sócioeconômico para compreensão dessas variabilidades.

A explicação das ocorrências das variabilidades orçamentárias pela teoria do Principal-Agente encontra alguns pontos como a preponderância do Poder Executivo no processo orçamentário (FORRESTER; 2002), denominada dominância do Executivo; e particularmente, as alterações verificadas no final, durante o pagamento dos restos a pagar, situação destacada dos achados, demonstra que os agentes ao final fazem determinações que podem não coincidir ou não levar em conta os desejos e interesses dos principais. Assim, os achados corroboram a sugestão de Giacomoni (2010), de que a 
programação financeira também incorpore a governança democrática e inclusiva e seja submetida ao crivo legislativo.

A utilização dos clusters não encontrou qualquer evidência do Political Budget Cycle $-P B C$, haja vista padrões de variação terem sido identificados como uniformes ao longo do tempo, não indicando comportamento diferenciado em períodos eleitorais, pelo menos dentro dos grupos de despesas abordados por este trabalho, segundo os critérios observados, inclusive em país como o Brasil, ao qual teria propensão maior (STREB; LEMA; TORRENS, 2003). Quanto a estudos sobre a influência do ciclo eleitoral, na política orçamentária, cabem outros estudos de clusters, mas com diferentes critérios, talvez abordando as modalidades de aplicação, que trata das transferências inter e intragovernamentais e a diferenciação entre gastos primários e financeiros.

O comportamento das dotações orçamentárias ao longo do tempo, dos diversos tipos e momentos do processo orçamentário aponta no caminho de certa previsibilidade e estabilidade temporal, não confirmando ou identificando nesse período situações abruptas, que poderia demonstrar a aplicabilidade do modelo do equilíbrio pontuado (JONES; BAUMGARTNER, 2012), com exceção dos já mencionados restos a pagar.

Aparentemente o modelo que melhor descreve o orçamento brasileiro no período da pesquisa é o incrementalismo (DAVIS; JONES; WILDAVSKY, 1966), tendo em vista sua estabilidade. Aparentemente o orçamento se comporta de forma incremental a maior parte do tempo. Cabe destacar que o período abordado, entre os exercícios de 2002 a 2012, pode ter sido insuficiente para detecção de pontos ocasionais e abruptos, como preconizado pelo equilíbrio pontuado, fato este que pode ser considerado uma limitação ao presente estudo. 
O modelo de julgamento serial (PADGETT, 1980), coerente com as decisões em sequências de etapas adotadas, ajuda a explicar parte do comportamento do processo orçamentário brasileiro. Assim, diante de situações para decisões dos valores a serem previstos para os programas governamentais, e face à impossibilidade oportuna de implementação de determinadas decisões, tem-se a opção de realizar ajustes pequenos, por meio de acréscimos e reduções, até que surjam condições para sua viabilização.

O padrão predominante demonstrou que entre os grupos de despesa do orçamento, considerados neste estudo, outras despesas correntes e de capital, investimentos, totais e emendas parlamentares individuais, não foi possível generalizar um comportamento como aderente a outro grupo, apesar de os padrões identificados terem sido próximos, à exceção do referente às despesas totais, cuja variação foi menor do que os demais, fato este justificado por esse grupo incluir os gastos majoritários dos orçamentos públicos federais, muitos deles obrigatórios, como pagamento de despesas de pessoal e serviços da dívida.

As diferenças comportamentais entre os tipos de unidades orçamentárias, tendo sido apontada que as entidades da Administração indireta tem maior variabilidade que aquelas integrantes da Administração direta, podem significar que a flexibilidade das instituições públicas é uma característica propícia a implementação de novas políticas, pois as variabilidades indicam maior mutação nos acordos estabelecidos, superando as fricções institucionais.

A possibilidade de identificar grupos institucionais e descrever seus padrões de comportamento orçamentário pode constituir-se em um instrumento importante para futuras pesquisas com vistas a sua correlação com estudos sobre a governança (BERSCH; PRAÇA; TAYLOR, 2013). Nesse sentido, a identificação de correlações pode colaborar 
em atividades para maior prevenção de riscos regulatórios, permitindo ações corretivas para redução dos impactos indesejáveis.

Entre as sugestões de novas pesquisas no tema, cabe mencionar o pressuposto de que há um conjunto elevado de observações destoantes e que, sob critérios diferentes de identificação e tratamento dessas observações, os resultados seriam também alterados, o que nesse estudo pode ter sido considerado uma limitação. Vale ainda considerar uma análise por clusters não hierárquicos como alternativa metodológica a ser explorada. Por fim, a ausência de estudos similares anteriores, outra limitação nesse estudo, aponta para o amplo espaço de análise e reflexão dos resultados, com a identificação de padrões que incorporem outras classificações orçamentárias e aprofundem o conhecimento das suas especificidades, posto que o principal achado da pesquisa sugere que a discricionariedade executiva de pagamento dos restos a pagar transforma o orçamento público em uma peça que não pode ser considerada um instrumento de planejamento. 


\section{REFERÊNCIAS}

ABRANCHES, S. H. H Presidencialismo de Coalizão: O Dilema Institucional Brasileiro. Revista de Ciências Sociais. Rio de Janeiro, v. 31, n. 1, p. 5-34, 1988.

ALVES, M. F. C.; SODRÉ, A C. A. Transferências Intergovernamentais Voluntárias: Relação entre Emendas Parlamentares e Corrupção Municipal no Brasil. $2^{\circ}$ Concurso de Monografias da Controladoria Geral da União. 2007.

BALASSONE, F.; GIORDANO, R. Budgets Deficits and Coalitions Governments. Public Choice. v. 106, n. 3/4, pp. 327-349, 2001.

BARBERIA, L. G.; AVELINO, G. Do Political Budget Cycles Differ in Latin Democracies? Economia. p. 101-145, Spring, 2011

BARCELOS, C. L. K. Quinze Anos sem Aaron Wildavsky: Recordando Lições Valiosas. ENCONTRO DE ADMINISTRAÇÃO PÚBLICA E GOVERNANÇA - ANPAD. Salvador-BA. 2008.

BAUMGARTER, F.R.; BREUNIG, C.; GREEN-PEDERSEN, C.; JONES, B. N.; MORTENSEN, P. B.; NUYTEMANS, M.; WALGRAVE, S. Punctuated Equilibrium in Comparative Perspective. American Journal of Political Science. v. 53, n. 3, p. 603620, Jul. 2009.

BERRY, W. D. The Confusing Case of Budgetary Incrementalism: Too Many Meanings for a Single Concept. The Journal of Politics. v. 52, n. 1, p. 167-196, Feb. 1990.

BERSCH, K.; PRAÇA, S. \& TAYLOR, M. M. State Capacity and Bureaucratic Autonomy Within National States: Mapping the Archipelago of Excellence in Brasil. In: THE LATIN AMERICAN STUDIES ASSOCIATION CONFERENCE. Washington D.C., 2013.

State Capacity, Bureaucratic Politicization, and Governance Outcomes. In: ANNUAL MEETING OF THE AMERICAN POLITICAL SCIENCE ASSOCIATION. Chicago, Illinois, Augusto 29-September 1, 2013.

BORGE, L.; FALCH, T.; TOVMO, P. Public Sector Efficiency: The Roles of Political and Budgetary Institutions, Fiscal Capacity, and Democratic Participation. Public Choice. v. 136, n. 3/4, p. 475-495, 2008.

BRASIL. Constituição da República Federativa do Brasil, de 5 de outubro de 1988. Disponível em: < http://www.planalto.gov.br/ccivil_03/Leis/LCP/Lcp101.htm>. Acesso em: 30 mai. 2013

Lei Complementar n. 101, de 4 de maio de 2000. Disponível em: <http://www.planalto.gov.br/ccivil_03/Constituicao/Constituiçao.htm>. Acesso em: 30 mai. 2013.

Lei n. 4.320, de 17 de março de 1964. Disponível em: <http://www.planalto.gov.br/ccivil_03/Constituicao/Constituiçao.htm>. Acesso em: 30 mai. 2013. 
Decreto-Lei n. 200, de 25 de fevereiro de 1967. Disponível em: <http://www.planalto.gov.br/ccivil_03/Constituicao/Constituiçao.htm>. Acesso em: 30 mai. 2013.

Ministério do Planejamento, Orçamento e Gestão. Manual Técnico de Orçamento. Versão 2015 - MTO-2015. Brasília, 2015 Disponível em: < www.portalsof.planejamento.gov.br/bib/MTO>. Acesso em: 13 abr. 2014

BREUNIG, C.; KOSKI, C. Punctuated Budgets and Governor's Institutional Powers. American Politics Research. v. 37, n. 6, p. 1116-1138, Nov. 2009.

CARROLL, R.; COX, G. W. Shadowing Ministers: Monitoring Partners in Coalition Governments. Comparative Political Studies, v. 45, n. 2, p. 220-236, 2012.

COSTA, G. P. C. L.; FREIRE, F. S.; GARTNER, I. R.; CLEMETE, A. As Escolhas Públicas Orçamentárias Federais no PPA 2008-2011: uma Análise da Perspectiva do Modelo Principal-Agente. Revista de Administração Pública, v. 47, n. 5, p. 1089-1116, 2013.

DAVIS, A. D.; DEMPSTER, M. A. H.; WILDAVSKY, A. A Theory of the Budgetary Process. The American Political Science Review. Vol. LX, noํㅜ 3, 1966.

. Towards a Predictive Theory of Government Expenditure: US Domestic Appropriations. British Journal of Political Science, v. 4, n.4, p. 419-452, Oct. 1974.

DEARDEN, J. A.; HUSTED, T. A. (1990). Executive Budget Proposal, Executive Veto, Legislative Override and Uncertainty: A Comparative Analysis of the Budgetary Process. Public Choice, v. 65, no 1, pp. 1-19.

EISENHARDT K. M. Agency Theory: An Assessment and Review. The Academy of Management Review, v. 14, n. 1, p. 57-74, 1989.

EVERITT, B. S.; LANDAU, S.; LEESE, M.; STAHL, D. Cluster Analysis. John Wiley and Sons, Ltd.,Publication. 5a ed., 2011.

FABRIZIO, S.; MODY, A.; CORSETTI, G.; TEMPLE, J.R.W. Can Budget Institutions Counteract Political Indiscipline? Economic Policy, v. 21, n. 48, p. 689-739, Oct. 2006.

FIGUEIREDO, A. C.; LIMONGI, F. Política Orçamentária no Presidencialismo de Coalizão.. $1^{\mathrm{a}}$ ed. Rio de Janeiro: Editora FGV, 2008. 182p.

Processo Orçamentário e Comportamento Legislativo: Emendas Individuais, Apoio ao Executivo e Programas de Governo. Revista de Ciências Sociais, v.48, n. 4, pp. 737-776 Rio de Janeiro, 2005.

FORRESTER, J. The Principal-Agent Model and Budget Theory in The Public Sector, editores: Aman Khan e W. Bartley Hildreth. Quorum Books, London, 2002.

FRANKLIN, A. L.; RAADSCHELDERS, J. C. N. Ethics in Local Government Budgeting: Is There a Gap Between Theory and Practice?. Public Administration Quartely, v. 27, n. 3/4, p. 456-490, 2004.

FUKUYAMA, F. “What is Governance?” Governance 26(3): 347-68.

GIACOMONI, J. Orçamento Público. 15ª ed. São Paulo: Ed. Atlas, 2010. 368p.

GOODMAN, D. Determinants of Perceived Gubernatorial Budgetary Influence Among State Executive Budget Analysts and Legislative Fiscal Analyst. Political Research Quartely, v. 60, n. 1, p. 43-54, 2007. 
GRAU, E. R. A Ordem Econômica na Constituição de 1988. 15a ed. São Paulo: Malheiros Editores, 2010, 383 p.

HIX, S.; NOURY, A.; ROLAND, G. Voting Patterns and Alliance Formation in the European Parliament. Philosophical Transactions: Biological Sciences, v. 364, n. 1518, p. 821-831, 2009.

HOPE, K. R. Capacity Development for Good Governance in Developing Societies: Lessons from the Field. Development in Practice, v. 19, n. 1, p. 79-86, Feb. 2009.

HYDE, A. C. The Development of Budgeting and Budget Theory: The Threads of Budget Reform.” In A.C. Hyde (ed.), Government Budgeting: Theory, Process, Politics. Pacific Grove, CA: Brooks/Cole Publishing, 1992: 1-6.

JANERT, P. K. Data Analysis with Open Source Tools. $1^{\text {a }}$ ed. Ed. O’Reilly, 2011, 509p.

JENSEN, M. C.; MECKLING, W. H. Theory of the Firm: Managerial Behavior, Agency Costs and Ownership Structure. Journal of Financial Economics, v. 3, n.4, p. 305-360, 1976.

JONES, B.D. Bounded Rationality. Annual Review of Political Science, n.2, pp. $297-$ 321, 1999.

JONES, B. D.; BAUMGARTNER, F. R. From There to Here: Punctuated Equilibrium to the General Punctuation Thesis to a Theory of Government Information Processing. The Policy Studies Journal, v. 40, n. 1, p. 1-19, 2012.

JONES, B. D.; BAUMGARTNER, F. R.; BREUNIG, C.; WLEZIEN, C.; SOROKA, S.; FOUCALT, M.; FRANÇOIS, A; GREEN-PEDERSEN C.; KOSKI, C. JOHN, P.; MORTENSEN, P. B.; VARONE, F.; WALGRAVE, S.. A General Empirical Law of Public Budgets: A Comparative Analysis. American Journal of Political Science, v. 53, n. 4, p. 855-873, Oct. 2009.

JONES, B.D. Bounded Rationality and Political Science: Lessons from Public Administration and Public Policy. Journal of Public Administration Research and Theory: J-Part, v. 13, n. 4, pp. 395-412, Oct. 2003.

LAGONA, F.; PADOVANO, F. A Nonlinear Principal Component Analysis of the Relationship between Budget Rules and Fiscal Performance in the European Union. Public Choice, v. 30, n. 3/4, p. 401-436, Mar. 2007.

LASSWELL, H. Politics: Who Gets What, When, How. New York: McGraw-Hill, 1936.

LAVAlle, A. G.; HOUTZAGER, P. P.; CASTELlO, G. Democracia, Pluralização da Representação e Sociedade Civil. Lua Nova, São Paulo: 67: 49-103, 2006.

LELOUP, L. T. Budget Theory for a New Century in Budget Theory in The Public Sector, editores: Aman Khan e W. Bartley Hildreth. Quorum Books, London, 2002.

LERUTH, L.; PAUL, E. A Principal-Agent Theory Approach to Public Expenditure Management Systems in Developing Countries. International Monetary Fund Working Paper, v.204, n.6, 2006.

MINK, M.; DE HAAN, J. Are There Political Budget Cycles in The Euro Area? European Union Politics, v. 7, n. 2, p. 191-211, 2006.

PADGETT, J. F. Bounded Rationality en Budgetary Research. The American Political Science Review, v. 74, n.2, p. 354-372, Jun. 1980. . 
PEDERIVA, J. H.; LUSTOSA, P. R. B. Créditos Extraordinários e Medidas Provisórias no Brasil: uma Análise Sistêmica. Revista de Administração ContemporâneaEletrônica, v. 1, n.2, p. 97-113, 2007.

PEREIRA, C.; MUELER, B. The Cost of Governing: Strategic Behavior of the President and Legislators in Brazil's Budgetary Process. Comparative Political Studies, v. 37, n. 7, p. 781-815, Sep. 2004.

Comportamento Estratégico em Presidencialismo de Coalizão: As Relações entre Executivo e Legislativo na Elaboração do Orçamento Brasileiro. Revista de Ciências Sociais, Rio de Janeiro, v. 45, n. 2, p. 265-301, 2002.

REPETTO, R. Punctuated Equilibrium and the Dinamycs of the U. S. Environmental Policy. The Quartely Review of Biology, v. 82, n. 3, p. 298, Sep. 2007.

ROBINSON, S. E.; CAVER, F.; MEIER, K. J.; O’TOOLE JR, L. J. Explaining Policy Punctuations: Bureaucratization and Budget Change. American Journal of Political Science, v. 51, n. 1, p. 140-150, Jan. 2007.

ROBINSON, S.; CAVER, F. Punctuated Equilibrium and Congressional Budgeting. Political Research Quartely, v. 59, n. 1, pp. 161-166, Jan. 2006.

RUBIN, I. Aaron Wildavsky and The Demise of Incrementalism. Public Administraciona Review, v. 49, n. 1, pp. 78-81, 1989.

SCHNEIDER, C. Fighting With One Hand Tied Behind The Back:Political Budget Cycles in The West German States. Public Choice, v. 142, p. 125-150, 2010.

SCHICK, A. The Federal Budget: Politics, Policy, Process. The Brookings Institution. Washington.D.C. Revised Edition, 2000.

SECCHI, L. Modelos Organizacionais e Reformas na Administração Pública. Revista de Administração Pública, Rio de Janeiro, v. 43, n. 2, p. 347-369, 2009.

SHI, M.; SVENSSON, J. Political Budget Cycles: A Review of Recent Developments. Nordic Journal of Political Economy, v. 29, p. 67-76, 2003.

STREB, J. M.; LEMA, D; TORRENS, G. Checks and Balances on Political Budget Cycles: Cross-Country Evidence. KYKLOS, v. 62, n.3, p. 426-447, August 2009.

SUZART, J. A. da S. Avaliando o Nível de Transparência Fiscal dos Processos Orçamentários Públicos Nacionais. REUNA, Belo Horizonte, v. 16, n. 3, p. 93-106, 2011.

VAUBEL, R. Principal-Agent Problems in International Organizations. The Review of International Organizations, v.1, n.2, p. 125-138, 2006.

WILDAVSKY, A. Political Implications of Budgetary Reform. Public Administration Review, v. 21, p. 183-190, 1961. 


\section{APÊNDICE A - Unidades orçamentárias por órgão - 2012}

\begin{tabular}{|c|c|}
\hline Órgão Setorial & $\begin{array}{l}\mathrm{N}^{\mathrm{o}} \text { de } \\
\text { unidades } \\
\text { vinculadas }\end{array}$ \\
\hline Câmara dos Deputados & 2 \\
\hline Senado Federal & 1 \\
\hline Tribunal de Contas da União & 1 \\
\hline Supremo Tribunal Federal & 2 \\
\hline Superior Tribunal de Justiça & 1 \\
\hline Justiça Federal & 6 \\
\hline Justiça Militar & 1 \\
\hline Justiça Eleitoral & 29 \\
\hline Justiça do Trabalho & 26 \\
\hline Presidência da República & 18 \\
\hline Ministério da Agricultura & 4 \\
\hline Ministério da Ciência, Tecnologia e Inovação & 8 \\
\hline Ministério da Fazenda & 10 \\
\hline Ministério da Educação & 146 \\
\hline Ministério do Desenvolvimento, Indústria e Comércio & 5 \\
\hline Ministério da Justiça & 12 \\
\hline Ministério de Minas e Energia & 6 \\
\hline Ministério da Previdência Social & 4 \\
\hline Ministério Público & 5 \\
\hline Ministério das Relações Exteriores & 2 \\
\hline Ministério da Saúde & 8 \\
\hline Ministério do Trabalho e Emprego & 3 \\
\hline Ministério dos Transportes & 7 \\
\hline Ministério das Comunicações & 4 \\
\hline Ministério da Cultura & 9 \\
\hline Ministério do Meio Ambiente & 8 \\
\hline Ministério do Planejamento, Orçamento e Gestão & 3 \\
\hline Ministério do Desenvolvimento Agrário & 2 \\
\hline Ministério do Esporte & 2 \\
\hline Ministério da Defesa & 17 \\
\hline Ministério da Integração Nacional & 6 \\
\hline Ministério do Turismo & 2 \\
\hline Ministério do Desenvolvimento Social e Combate à Fome & 2 \\
\hline Ministério das Cidades & 5 \\
\hline Ministério da Pesca e Aquicultura & 1 \\
\hline
\end{tabular}
Fonte: Autor 


\section{APÊNDICE B - Evolução temporal dos tipos de unidades}

\section{orçamentárias}

\begin{tabular}{|l|l|l|l|l|l|l|l|l|l|l|l|l|l|}
\hline Tipos UOs & 2000 & 2001 & 2002 & 2003 & 2004 & 2005 & 2006 & 2007 & 2008 & 2009 & 2010 & 2011 & 2012 \\
\hline $\begin{array}{l}\text { Adm. } \\
\text { direta }\end{array}$ & 110 & 108 & 108 & 114 & 115 & 115 & 119 & 121 & 132 & 122 & 121 & 119 & 127 \\
\hline $\begin{array}{l}\text { Adm. } \\
\text { indireta }\end{array}$ & 182 & 186 & 186 & 196 & 192 & 189 & 193 & 196 & 185 & 276 & 201 & 209 & 217 \\
\hline Fundos & 43 & 50 & 47 & 48 & 41 & 41 & 41 & 39 & 40 & 40 & 38 & 38 & 39 \\
\hline $\begin{array}{l}\text { Órgãos } \\
\text { virtuais }\end{array}$ & 9 & 9 & 9 & 9 & 22 & 20 & 22 & 24 & 24 & 27 & 32 & 32 & 37 \\
\hline
\end{tabular}

Fonte: Autor 